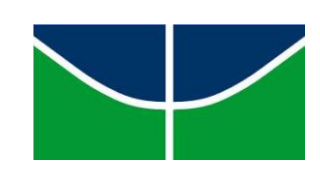

Universidade de Brasília - UnB

Instituto de Ciências Humanas - IH

Departamento de Serviço Social - SER

Programa de Pós-Graduação em Política Social - PPGPS

DISSERTAÇÃO DE MESTRADO

\title{
ASSISTÊNCIA SOCIAL NO CONTEXTO DO WORKFARE: UMA ANÁLISE DO PROGRAMA NACIONAL DE ACESSO AO ENSINO TÉCNICO E EMPREGO - BRASIL SEM MISÉRIA (PRONATEC - BSM)
}

Camila Guimarães Torres 
CAMILA GUIMARÃES TORRES

\section{ASSISTÊNCIA SOCIAL NO CONTEXTO DO WORKFARE: UMA ANÁLISE DO PROGRAMA NACIONAL DE ACESSO AO ENSINO TÉCNICO E EMPREGO - BRASIL SEM MISÉRIA (PRONATEC - BSM)}

Dissertação de Mestrado apresentada ao
Programa de Pós-Graduação em Política
Social do Departamento de Serviço Social
da Universidade de Brasília - UnB, como
requisito parcial à obtenção do título de
Mestre em Política Social.
Orientadora: Prof. ${ }^{\text {a }}$ Dra ${ }^{\text {a }}$ Rosa Helena Stein 
CAMILA GUIMARÃES TORRES

Assistência social no contexto do workfare: uma análise do Programa Nacional de Acesso ao Ensino Técnico e Emprego - Brasil Sem Miséria (PRONATEC - BSM)

Dissertação de Mestrado apresentada ao Programa de Pós-Graduação em Política Social do Departamento de Serviço Social da Universidade de Brasília - UnB, como requisito parcial à obtenção do título de Mestre em Política Social.

\title{
BANCA EXAMINADORA
}

\author{
Prof. ${ }^{\text {a }}$ Dra . Rosa Helena Stein
}

(Orientadora - SER/UnB)

Prof. ${ }^{a}$ Dra . Camila Potyara Pereira

(SER/UnB)

Prof. ${ }^{a}$ Dra . Maísa Miralva da Silva

(PUC/GO)

Prof. $^{a}$ Dr $^{a}$. Sandra Oliveira Teixeira

(Suplente - SER/UnB) 
Ficha catalográfica elaborada automaticamente, com os dados fornecidos pelo(a) autor(a)

\section{Guimarães Torres, Camila}

GT693a Assistência social no contexto do workfare: uma análise do Programa Nacional de Acesso ao Ensino Técnico e Emprego - Brasil Sem Miséria (PRONATEC BSM) / Camila Guimarães Torres; orientador Rosa Helena Stein. -- Brasília, 2016.

$$
101 \text { p. }
$$

Dissertação (Mestrado - Mestrado em Política Social) -- Universidade de Brasília, 2016.

1. Assistência social. 2. workfare. 3. Ativação. 4. Pronatec. 5. Trabalho. I. Stein, Rosa Helena, orient. II. Título. 
$\grave{A}$ vida e as suas surpresas. 


\section{AGRADECIMENTOS}

À minha orientadora, Prof ${ }^{a}$. Dr ${ }^{\mathrm{a}}$. Rosa Helena Stein, por ser um exemplo de pessoa e profissional. E pela confiança, paciência e carinho durante esta caminhada, cheia de percalços e dificuldades. Sem você este trabalho não seria possível.

Às Prof ${ }^{a}$. Dr ${ }^{a}$. Camila Potyara Pereira e Sandra Oliveira Teixeira, pelas ricas contribuições durante a banca de qualificação do projeto de pesquisa. Obrigada por terem aceitado estar na banca de defesa desta dissertação e pelo apoio e força dados para conclusão deste trabalho.

À Ana Alice Meirelles, assistente social e chefe do Núcleo de Serviço Social do Hospital Regional da Asa Norte - HRAN, que de forma compreensiva e generosa apoiou e proporcionou os meios que contribuíram para finalização desta dissertação.

Aos amigos e colegas, que direta ou indiretamente me apoiaram e deram força para conclusão desta dissertação. 
RESUMO

\section{Assistência social no contexto do workfare: uma análise do Programa Nacional de Acesso ao Ensino Técnico e Emprego - Brasil Sem Miséria (PRONATEC - BSM)}

Constitui objeto de estudo desta dissertação a análise das contradições, concepções e tendências presentes na política de assistência social brasileira, relacionadas à lógica do workfare (bemestar em troca de trabalho) e a mecanismos de ativação de seus demandantes, a partir da análise do Programa Nacional de Acesso ao Ensino Técnico e Emprego - Brasil Sem Miséria (PRONATEC - BSM). A expansão do workfare na atualidade traduz-se como a obrigatoriedade do trabalho ou de fornecimento de uma contrapartida em troca de proteção social, resultando em mudanças na forma de regulação do Estado capitalista, que passa a ter um viés schumpeteriano, e, concomitantemente, influenciando na configuração dada às políticas sociais, que se tornam cada vez mais mercadorizáveis e deixam de se guiar pelo imperativo da satisfação das necessidades humanas. Uma das políticas sociais que vem incorporando com mais nitidez essa tendência é a assistência social, por meio de sua relação com as medidas de ativação, haja vista sua contradição histórica com o trabalho. A pesquisa realizada possui caráter documental, se guiou pelo método do materialismo dialético e utilizou o estudo de caso do PRONATEC BSM. O programa foi escolhido por ser paradigmático, ao expressar a relação entre assistência social e ativação no contexto brasileiro, uma vez que é operacionalizado pelas unidades de assistência social e possui como objetivo a oferta de qualificação profissional a beneficiários de transferência de renda e a pessoas inscritas ou em processo de inscrição no Cadastro Único para Programas Sociais do Governo Federal. Os resultados encontrados demonstram que, apesar das especificidades do desenvolvimento do Estado social no Brasil, há uma tendência crescente de incorporação dos princípios do workfare, principalmente por meio da mediação da política de assistência social, que tem apresentado caráter tecnicista e burocrático, ao basear cada vez mais suas ações em procedimentos relacionados ao Programa Bolsa Família. Nesse sentido, o PRONATEC - BSM constitui o principal programa que permite a ativação de usuários da assistência social atualmente, além de reforçar mecanismos de focalização, possuir pouca abrangência e eficácia, demonstrando que sua continuidade pode ser atribuída ao apelo político que possui e ao aspecto subjetivo, o que, por sua vez, ratifica as ideias correntes ventiladas de promoção da autonomia, emancipação e empoderamento.

Palavras-chave: Assistência social. Workfare. Ativação. Pronatec. Trabalho. Estado. 


\section{ABSTRACT}

Social assistance in the context of workfare: an analysis of the National Program for Access to Technical Education and Employment - Brazil Without Poverty (PRONATEC - BSM)

It is object of this dissertation study the analysis of contradictions, concepts and tendencies in the Brazilian social welfare policy, related to the logic of workfare (welfare in exchange of work) and its plaintiffs activation mechanisms. The expansion of workfare today is translated as the obligation to work or to provide something in exchange for social protection, resulting in changes in the regulation of the capitalist state which happens to have a Schumpeterian bias, and, concomitantly, influencing in the given configuration of social policies, which become increasingly tradeable and cease to be guided by the imperative of satisfaction of human needs. One of the social policies that has been incorporating more clearly this trend is social assistance, through its relationship with the activation measures, given its historical contradiction with the work. The research made has documentary characterization, it was guided by dialectical materialism method and used the case study of the National Program for Access to Technical Education and Employment (PRONATEC - BSM). This program was chosen because it is paradigmatic as it express the relationship between social assistance and activation in the Brazilian context, since it is operated by social assistance units and has aimed to offer professional training to beneficiaries of income transference and to people enrolled or in registration process in the Single Registry for Social Programs of the Federal Government. The results found show that, despite the specifics of the welfare state development in Brazil, there is a growing trend of incorporating workfare principles, mainly through the mediation of social welfare policy, which has shown technicality and bureaucratic character, basing increasingly its actions in procedures related to the Bolsa Família Program. In this sense, PRONATEC BSM is the main program that allows the activation of current users of social assistance, in addition to strengthening targeting mechanisms, having little scope and effectiveness, demonstrating that its continuity can be attributed to political appeal to features and subjective appearance, which, in turn, confirms the current ideas ventilated of promotion of autonomy, emancipation and empowerment.

Keywords: Social assistance. Workfare. Activation. Pronatec. Work. State. 


\section{LISTA DE TABELAS}

Tabela 1 - Dimensão de Análise: Configuração e abrangência dos direitos garantidos pelo PRONATEC - BSM

Tabela 2 - Dimensão de Análise: Gestão do PRONATEC - BSM 80

Tabela 3 - Dimensão de Análise: Características da ativação para o trabalho do PRONATEC - BSM 


\section{LISTA DE GRÁFICOS}

Gráfico 1 - Situações frequentemente identificadas no território de abrangência dos CRAS (2011 a 2013) .72

Gráfico 2 - Ações realizadas pelos CRAS por público .73

Gráfico 3 - Percentual de municípios que desenvolve ações, programas, ou projetos de inclusão produtiva para geração de trabalho e renda (2011 a 2014) 75

Gráfico 4 - Percentual de municípios que desenvolve ações, programas, ou projetos de qualificação ou capacitação profissional (2011 a 2014) .76

Gráfico 5 - Percentual de municípios que encaminha os usuários da assistência social por oportunidades no mercado de trabalho

Gráfico 6 - Comparação entre quantidade de matrículas do PRONATEC-BSM com a quantidade de famílias inseridas no CadÚnico e famílias beneficiárias do PBF (2012 a 2014)

Gráfico 7 - Quantidade de matrículas do PRONATEC-BSM por região (2012 a 2014) 


\section{LISTA DE ABREVIATURAS E SIGLAS}

ACESSUAS/TRABALHO - Programa Nacional de Promoção do Acesso ao Mundo do Trabalho

BPC - Benefício de Prestação Continuada

CadÚnico - Cadastro Único para Programas Sociais do Governo Federal

CAS-DF - Conselho de Assistência Social do Distrito Federal

CAP - Caixa de Aposentadoria e Pensões

CFESS - Conselho Federal de Serviço Social

CRAS - Centro de Referência de Assistência Social

CREAS - Centro de Referência Especializado de Assistência Social

CNI - Confederação Nacional da Indústria

CNAS - Conselho Nacional de Assistência Social

CRESS-DF - Conselho Regional de Serviço Social $8^{a}$ Região

DRU - Desvinculação das Receitas da União

FTSUAS-DF - Fórum de Trabalhadores do SUAS do Distrito Federal

FMI - Fundo Monetário Internacional

IAPs - Institutos de Aposentadorias e Pensões

LBA - Legião Brasileira de Assistência

LOPS - Lei Orgânica de Previdência Social

LOAS - Lei Orgânica da Assistência Social

MDS - Ministério do Desenvolvimento Social e Combate à Fome

MDSA - Ministério do Desenvolvimento Social e Agrário

MPAS - Ministério da Previdência e Assistência Social

NOB-SUAS - Norma Operacional Básica do SUAS

NOB/RH-SUAS - Norma Operacional Básica de Recursos Humanos

ONU - Organizações das Nações Unidas

OCDE - Organização para Cooperação e Desenvolvimento Econômico

OIT - Organização Internacional do Trabalho

PBF - Programa Bolsa Família 
PAIF - Serviço de Proteção e Atendimento Integral à Família

PCS - Programa Comunidade Solidária

PRONATEC-BSM - Programa Nacional de Acesso ao Ensino Técnico e Emprego - Brasil Sem Miséria

PNAS - Política Nacional de Assistência Social

PLANFOR - Plano Nacional de Qualificação do Trabalhador

PNPE - Programa Nacional de Estímulo ao Primeiro Emprego

PNQ - Plano Nacional de Qualificação

PPGPS - Programa de Pós-Graduação em Política Social

SAGI - Secretaria de Avaliação e Gestão da Informação

SEDESTMIDH - Secretaria de Estado de Trabalho, Desenvolvimento Social, Mulheres, Igualdade Racial e Direitos Humanos

SENAC - Serviço Nacional de Aprendizagem Comercial

SENAI - Serviço Nacional de Aprendizagem Industrial

SUAS - Sistema Único de Assistência Social

UE - União Europeia 


\section{SUMÁRIO}

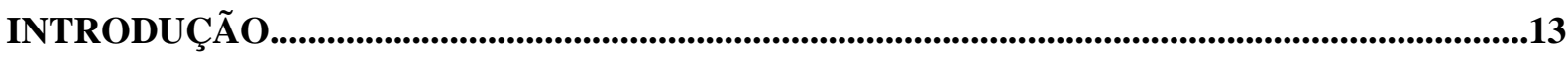

CONTEXTUALIZAÇÃO E DELIMITAÇÃO DO PROBLEMA DE PESQUISA ………………………………………...13

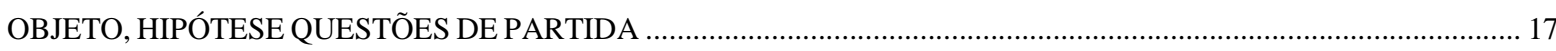

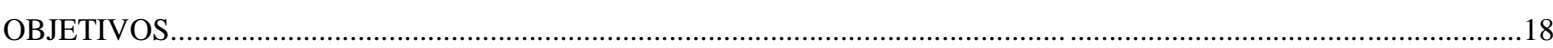

JUSTIFICATIVA.

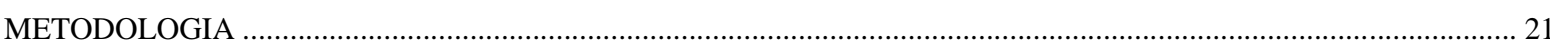

1. Método

2. Procedimentos Metodológicos ..................................................................................................................................2

CAPÍTULO 1 - TRABALHO, CRISE DO CAPITAL E OS EFEITOS DELETÉRIOS PARA A

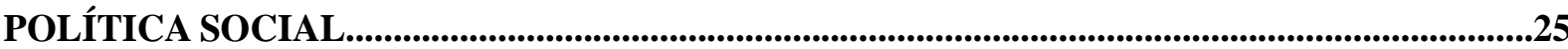

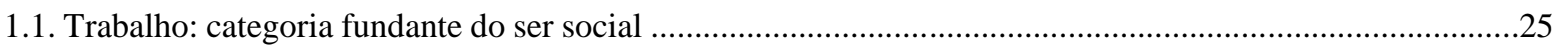

1.2. Do fordismo ao toyotismo: trabalho na conjuntura atual ........................................................................... 30

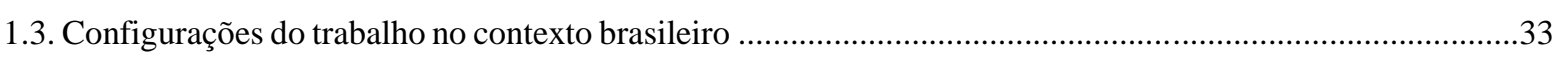

1.4. Crise estrutural do capital e o ataque aos direitos e as políticas sociais ............................................................34

1.5. Efeitos da crise do capital para o mundo do trabalho ………..........................................................................39

CAPÍTULO 2 - ESTADO DE WORFARE E ATIVAÇÃo PARA O TRABALHO: CARACTERÍSTICAS E CONFIGURAÇÃO ATUAL ..........................................................41

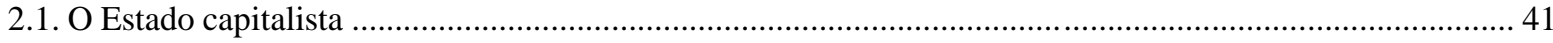

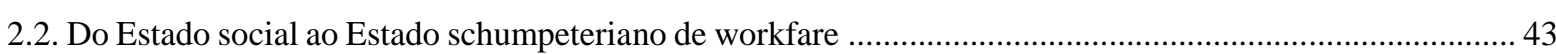

2.3. Workfare: a lógica do trabalho como obrigação ou contrapartida .....................................................................

2.4. Flexiseguridade e ativação para o trabalho. ................................................................................................

CAPÍTULO 3 - ASSISTÊNCIA SOCIAL E TRABALHO: UMA CONTRADIÇÃO HISTÓRICA

E ATUAL................................................................................................................................................................54

3.1. Assistência social como política de seguridade social .............................................................................54

3.2. Assistência social na atualidade: do percurso histórico do favor ao direito e possível retorno ao passado?

3.3. Contradição histórica entre assistência social e trabalho e suas expressões na contemporaneidade ...............62

CAPÍTUlO 4 - POLÍticas DE TRABALHO NO BRASIL E O ESTUdO DE CASO NO

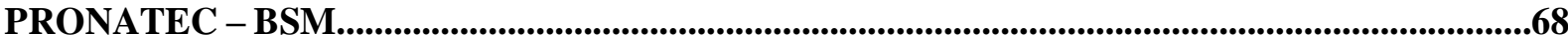

4.1. Política de trabalho no Brasil: breve histórico das ações de qualificação profissional ............................... 68

4.2. Assistência social e inclusão produtiva: uma relação persistente ..............................................................70

4.3.O PRONATEC - BSM como estratégia de ativação dos demandantes de assistência social..........................76

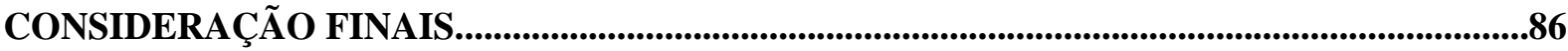

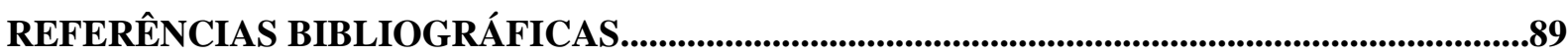




\section{INTRODUÇÃO}

\section{CONTEXTUALIZAÇÃO E DELIMITAÇÃO DO PROBLEMA DE PESQUISA}

O Estado teve papel determinante no avanço do modo de produção capitalista, constituindo-se um mecanismo de acumulação do capital e instrumento legítimo de dominação e coerção. Segundo Mandel (1982), o capital não consegue produzir a si mesmo sozinho e necessita de uma instituição independente, que possa satisfazer suas necessidades, portanto, o Estado é compreendido como uma ferramenta de preservação do próprio capital. O autor menciona ainda o que chama de "ilusões" do Estado social, isto é, o entendimento equivocado de alguns estudiosos, que baseados em uma visão unívoca e até mesmo ingênua, acreditam que o Estado social promoveria a redistribuição de renda, por meio de políticas sociais, retirando do capital e dando ao trabalho. Nesse sentido, Boschetti (2016) afirma que os termos welfare state ou bem-estar social, atribuídos ao Estado em conjuntura histórica específica, muitas vezes mascaram a verdadeira natureza do Estado capitalista.

Nas últimas décadas, o Estado capitalista vem deixando de praticar o welfare (bemestar), para então realizar o denominado workfare (bem-estar em troca de trabalho ou contrapartida), caracterizando assim a passagem do Estado social para o Estado de labor, ou de pró-trabalho (PEREIRA-PEREIRA, 2009). Essa mudança é, na verdade, um processo amplo e complexo, consequência da própria dinâmica destrutiva do capital, que por meio de sua crise estrutural, tem afetado as variadas esferas da vida social, da economia, da política e das características do próprio Estado, componente estratégico da dinâmica de acumulação.

A expansão das características que conformam o workfare podem ser situadas a partir da crise econômica da década de 1970, atribuída pelo corolário liberal ao fracasso do regime de acumulação fordista e às medidas keynesianas do Estado social. Todavia, esse discurso é falacioso, tendo em vista que as crises econômicas fazem parte da própria dinâmica de produção e reprodução do capital, portanto, possuem uma causa única, apesar de suas expressões fenomênicas serem diferentes. A crise do capital é então compreendida como estrutural (MÉSZAROS, 2009), fruto das contradições capitalistas, na busca de acumulação e cada vez mais lucro.

Nesse sentido, o surgimento do workfare está intrinsecamente vinculado ao modelo de regulação econômica e social neoliberal, cuja doutrina foi imposta aos países capitalistas por meio do Consenso de Washington, e sua justificativa teórica está fundamentada no pensamento 
schumpeteriano $^{1}$ (PEREIRA-PEREIRA, 2009), que ganhou força nesse período. Para Jessop (1993), há uma convergência da mudança do Estado keynesiano, que garantia bem-estar, para um Estado schumpeteriano, de pró-trabalho.

O schumpeterianismo confere ao Estado uma lógica baseada na inovação e no empreendedorismo, a fim de extrair cada vez mais lucro do processo produtivo. Segundo Arienti (2003), as políticas baseadas nesse ideário atuariam no sentido de promover a capacidade de inovação das empresas, aumentando a competitividade, impondo aos trabalhadores a necessidade de qualificação para um mercado de trabalho flexibilizado, com objetivo de diminuir os custos para os capitalistas. Para o autor, o objetivo do pensamento schumpeteriano é subordinar a política social aos interesses privados, no sentido de uma dinâmica produtivista e mercantil, preocupada com a competitividade do regime pró-trabalho (ARIENTI, 2003).

O surgimento do termo workfare é atribuído ao contexto estadunidense e provem da contração da expressão welfare to work. Não existe consenso sobre seu conceito, por isso, as definições muitas vezes divergem quanto ao conteúdo de acordo com os diferentes autores. De maneira geral, o termo workfare pode ser compreendido como uma imposição de ações voltadas para o trabalho, com comprometimento de um comportamento ativo por parte do demandante, em troca de recebimento de serviços, auxílios ou prestações sociais. Para Barbosa (2013), o workfare também pode ser apreendido em seu sentido amplo, incluindo não só as políticas com sanções, mas também aquelas que possuem uma mobilização subjetiva para o trabalho e para outros tipos de ações ou serviços.

Uma das principais formas em que o workfare tem se expressado na atualidade se dá através das políticas de ativação, também denominadas como políticas ativas ou simplesmente medidas de ativação, consideradas como um importante mecanismo de inserção no mercado laboral, haja vista a expansão do desemprego pelo mundo. Apesar de seu crescimento nas últimas décadas, que também pode ser atribuído aos imperativos e recomendações dos organismos internacionais, as políticas de ativação não possuem um conceito uniforme e têm como principal característica a heterogeneidade, tendo em vista as especificidades e variações que possuem nos diferentes países, isto é, em alguns possuem caráter obrigatório e natureza punitiva, enquanto em outros, não há obrigatoriedade ou sanções de qualquer tipo.

\footnotetext{
${ }^{1} \mathrm{O}$ pensamento schumpeteriano faz referência às ideias do economista austríaco Joseph Schumpeter (1883 1950), que divulgou sua produção teórica durante a primeira metade do século XX.
} 
Segundo Barbosa (2013), o conceito de ativação não se limita à inserção no trabalho, apesar de sua definição mais usual sempre estabelecer essa relação, também se destacam nesse contexto a exigência de contrapartidas e as ações que envolvem processos educacionais de qualificação profissional. Wacquant (2003), ao pesquisar as configurações do workfare estadunidense, chama a atenção para o learnfare, que se baseia na exigência de contrapartida vinculada à educação, com obrigatoriedade de inserção de demandantes em escolas ou cursos profissionalizantes, em troca de proteção social mínima. De acordo com o autor, essa lógica reproduz a desigualdade do mercado de trabalho, com oferta de cursos associados a trabalhos precários e subalternos.

De forma geral, a dinâmica de funcionamento do workfare responsabiliza os indivíduos pela situação de desproteção, transforma políticas sociais em trampolins ${ }^{2}$ e assim reforça o primado liberal do trabalho, com resgate do julgamento moral e de mérito individual sobre a possibilidade de receber alguma prestação social ou serviço sem estar inserido no mercado de trabalho. É então desconstruída a ideia de proteção social como um direito de cidadania, cujo objetivo é o atendimento das necessidades humanas. A partir da lógica workfareana, as políticas sociais passam a ser mercadorizáveis, com favorecimento da rentabilidade econômica e dos interesses do capital.

Ao contrário dos países do capitalismo central, que tiveram com o advento do Estado social a implementação de políticas sociais de caráter universalista, baseadas na perspectiva de cidadania e posteriormente sofreram mais acintosamente as mudanças trazidas com o workfare, o desenvolvimento do capitalismo no Brasil foi marcado pela inserção periférica, e pelo chamado desenvolvimento desigual e combinado, que define a constituição da formação brasileira, caracterizada pela irregularidade, contradição e dependência (BEHRING e BOSCHETTI, 2008). Essas características também situam um padrão diferenciado da exploração da força de trabalho no país, e das formas de enfrentamento da questão social ao longo da história. Abordada durante um longo período como "caso de polícia", por meio de ações de caráter repressivo, o trato da questão social no Brasil demonstrou a frágil organização da classe trabalhadora, dada as especificidades da relação entre capital e trabalho no país (FILHO, 1982).

Ainda que no Brasil o desenvolvimento do Estado social tenha ocorrido de maneira diversa dos países do capitalismo central, dada as particularidades históricas já mencionadas, é

\footnotetext{
${ }^{2} \mathrm{O}$ termo "trampolim" é uma metáfora utilizada para designar o fenômeno em que as políticas sociais deixam de ser associadas a perspectiva de direito e passam a ser meros instrumentos da lógica de ativação, isto é, passam a ser associadas apenas como uma forma de acesso ao trabalho, em sua maioria precário e informal.
} 
possível verificar na conjuntura brasileira como o ideário do workfare pode estar presente nas políticas sociais, sobretudo, com relação à política de assistência social. Historicamente, a assistência social assumiu como público de sua atenção, a população considerada inapta para o trabalho, isto é, indivíduos que possuíam algum tipo de incapacidade de trabalhar, como idosos, crianças, deficientes, que devido a sua condição, eram considerados "merecedores" de assistência (BOSCHETTI, 2003). Contudo, diante das mudanças contemporâneas, a assistência social passa também a assumir, por período determinado, os aptos para o trabalho, que estão em situação de desemprego ou em empregos precarizados e de baixo rendimento (SITCOVSKY, 2010a).

Nesse sentido, os programas de transferência condicionada de renda passam a ser o mecanismo mais comum que o Estado, por meio da política de assistência social, tem utilizado para alcançar parcialmente os pobres capazes para o trabalho. É destinado o repasse de valores baixos, para que o benefício não seja considerado uma substituição real ao trabalho, e, consequentemente, seja mais digno para o indivíduo procurar um emprego, do que receber um benefício de valor irrisório, que estigmatiza e humilha quem recebe (PEREIRA-PEREIRA, 1996). Além disso, são provisões de caráter temporário, atreladas geralmente a um conjunto de condicionalidades e contrapartidas, que sob uma lógica meritocrática, objetivam que o indivíduo busque autonomia, por meio do desenvolvimento de suas próprias capacidades.

Nesta conjuntura, as medidas de ativação para o trabalho são valorizadas e vistas como mecanismo ideal de saída da condição de usuário da assistência social e/ou beneficiário de transferência de renda, para indivíduo que busca sua autonomia por meio do trabalho ou da preparação para este. Tais características coadunam com as tendências da política social na atualidade, sobretudo de ativação da população pobre inserida em programas focalizados ou daqueles aptos para o trabalho que não são público de programas de transferência de renda, mas que são usuários da assistência social. Segundo Souza (2013), resultados de pesquisas apontam que são destinados recursos da assistência social para ações de inclusão produtiva, que em sua maioria, são programas ou projetos de qualificação profissional ou inclusão por meio do trabalho (SOUZA, 2013).

Nos últimos anos, grande parte dessas ações tem ocorrido através do Programa Nacional de Acesso ao Ensino Técnico e Emprego (PRONATEC - BSM), que em decorrência de sua articulação com o Plano Brasil sem Miséria, possui como destinatários os beneficiários de programas de transferência de renda, isto é, aqueles que recebem o Benefício de Prestação Continuada (BPC), Programa Bolsa Família (PBF) ou ainda aqueles que estão cadastrados ou 
em processo de cadastramento no Cadastro Único para Programas Sociais do Governo Federal (CadÚnico). Portanto, o programa apresenta íntima relação com a política de assistência social, e torna-se paradigmático para compreensão da associação entre esta e as ações de inclusão produtiva, haja vista que as matrículas são realizadas nas unidades de assistência social e, por isso, voltadas aos usuários da política.

Face ao exposto, o problema de pesquisa que motivou a realização desta pesquisa, pode ser situado a partir da reestruturação do modo de intervenção do Estado capitalista, no qual o welfare (bem-estar) cede espaço para o workfare (bem-estar em troca de trabalho ou contrapartida) e das consequências dessa transição para o campo das políticas sociais. Nesse âmbito, destaca-se a contradição histórica entre assistência social e trabalho, e o ideário que tem guiado as políticas sociais na conjuntura de diferentes países, que se baseia no resgate de velhos princípios liberais, que conferem ao trabalho o principal lócus de bem-estar na sociedade, ainda que inserido num contexto de flexibilização e precarização, com destaque dado aos aspectos punitivos e moralizantes, que atribuem aos sujeitos à responsabilidade individual de prover sua própria sobrevivência. Nesse sentido, uma das principais expressões da lógica do workfare se dá através das medidas de ativação para o trabalho, consideradas como alternativa ideal para que os indivíduos desempregados, que recebem algum tipo prestação social ou serviço do Estado, não dependam durante muito tempo desses benefícios e consigam prover seu próprio bem-estar, de forma autônoma e individual. No contexto brasileiro, chama a atenção a crescente incorporação de discursos e práticas, que explícita ou implicitamente associam à assistência social à necessidade de inserção de seus demandantes no mercado de trabalho, principalmente, por meio da inclusão produtiva, sob o discurso da promoção da autonomia e das capacidades. Com isso, demonstra-se a necessidade de um estudo ancorado na perspectiva crítica sobre a política de assistência social brasileira e de que forma esta passa a incorporar o ideário do workfare.

\section{OBJETO, HIPÓTESE E QUESTÕES DE PARTIDA}

Constitui objeto privilegiado de estudo desta dissertação a análise da política de assistência social brasileira, a partir da mudança do padrão de regulação estatal, que promove a expansão da lógica do workfare e de mecanismos de ativação para o trabalho de demandantes desta política, no qual o PRONATEC - BSM torna-se uma expressão.

Portanto, a hipótese defendida neste estudo é de que com o processo de transição do Estado social para o Estado de labor ou de pró-trabalho, ocorreram mudanças significativas na 
configuração das políticas sociais, que passam a privilegiar a rentabilidade econômica e os interesses do capital em detrimento da satisfação das necessidades humanas, por meio dos direitos de cidadania. Embora no Brasil exista uma conformação específica do Estado social, devido a particularidade histórica e inserção periférica do país no capitalismo mundial, acreditase que a ideologia do workfare, isto é, a garantia de proteção social em troca de trabalho ou contrapartida, está presente no contexto brasileiro. Nesse sentido, a assistência social é uma das políticas sociais que podem ser consideradas mais sensíveis a essa lógica, pois possui uma contradição ideológica e histórica com o trabalho, cuja ideia subjacente é de que se existisse emprego para todos, não haveria necessidade da existência dessa política, ou seja, apesar de seu caráter gratuito e não contributivo, passa a ser vista como mercadorizável. Portanto, por incorporar com maior clareza a feição workfareana, a assistência social também estabelece uma relação próxima com as medidas de ativação, compreendidas não somente como ações de inserção no mercado de trabalho, mas também como o estabelecimento de diferentes contrapartidas para acesso ou manutenção de benefícios, serviços, programas ou projetos. Essa tendência é entendida como perniciosa, na medida em que reforça a lógica do workfare e situa a assistência social como uma política mercadorizável, compreendida de forma limitada como uma porta de saída ou um trampolim.

As seguintes questões de partida foram formuladas com o objetivo de guiar a pesquisa realizada: Quais as principais características do workfare na atualidade? Como a relação histórica e contraditória entre trabalho e assistência social se manifesta atualmente? De que maneira o ideário do workfare e as medidas de ativação se relacionam com a política de assistência social? Como a política de assistência social passa a incorporar as características e ações de origem workfareana?

\section{OBJETIVOS}

\section{Objetivo Geral}

Analisar as contradições, concepções e tendências presentes na política de assistência social brasileira, que possam estar relacionadas com a lógica do workfare (bem-estar em troca de trabalho) e de mecanismos de ativação de seus demandantes.

\section{Objetivos Específicos}

- Identificar as particularidades assumidas pela política de assistência social brasileira no contexto recente, a partir da contradição histórica existente entre trabalho e assistência; 
- Caracterizar as mudanças do papel do Estado capitalista, quando medidas de workfare passam a ser prioritárias frente as de welfare, a fim de identificar as principais transformações ocorridas nas políticas sociais contemporâneas;

- Caracterizar o workfare e a medidas de ativação para o trabalho, assim como os principais paradigmas que lhe conformam.

\section{JUSTIFICATIVA}

O interesse pela temática abordada nesta dissertação, surgiu da trajetória profissional desta pesquisadora enquanto trabalhadora do Sistema Único de Assistência Social (SUAS) no Distrito Federal. Durante o período de 2009 até meados de 2016, foi realizado trabalho na então Secretaria de Estado de Trabalho, Desenvolvimento Social, Mulheres, Igualdade Racial e Direitos Humanos (SEDESTMIDH), como servidora de nível médio, e, posteriormente, como assistente social. No decorrer da atuação profissional, com a experiência em diferentes áreas, como no Centro de Referência Especializado de Assistência Social (CREAS), Centro de Referência de Assistência Social (CRAS), assim como no campo da gestão, percebeu-se no cotidiano profissional questões e práticas que revelavam a contradição entre trabalho e assistência social, expressa por meio de programas, projetos, benefícios e até mesmo ações individuais de outros trabalhadores, que acabavam por responsabilizar a política de assistência social pela inclusão no mercado de trabalho da população demandante, sobretudo daqueles que são beneficiárias de programas de transferência condicionada de renda.

Destaca-se ainda como uma das motivações para este estudo, a militância na área da assistência social, que permitiu um acúmulo de conhecimento significativo, por meio da participação no Fórum de Trabalhadores e Trabalhadoras do SUAS do Distrito Federal (FTSUAS-DF), assim como no Conselho de Assistência Social do Distrito Federal (CAS-DF), enquanto conselheira titular representante do Conselho Regional de Serviço Social $8^{\text {a }}$ Região (CRESS-DF). Ademais, durante o percurso acadêmico, também foram fontes de inspiração, disciplinas e eventos sobre o tema aqui abordado, assim como a disciplina optativa do mestrado do Programa de Pós-Graduação em Política Social (PPGPS), "Política de Assistência e Seguridade Social", que foi cursada ainda como aluna especial.

A despeito da importância desta temática, ainda são escassos os estudos e produções acadêmicas ancorados na perspectiva crítica, muito embora alguns pesquisadores venham se dedicando mais a este tema nos últimos anos. Em outros países, sobretudo na Europa, onde as políticas de ativação se apresentam com maior nitidez, os estudos desse tipo são em maior 
número. Nesse sentido, é premente que sejam realizadas novas pesquisas, que analisem o processo de expansão do workfare, situando as características do Estado de labor ou de prótrabalho e as consequências para as políticas sociais, em especial para a assistência social.

A partir dos efeitos da crise do capital, que passam a se expressar de maneira mais nítida nos últimos quarenta anos, e das medidas de administração dessa crise, que visam salvaguardar a reprodução do capital, percebem-se inúmeras tentativas de desmonte dos sistemas de proteção social nos mais diversos países do mundo. Com o advento do neoliberalismo associado ao pensamento schumpeteriano, percebe-se um conjunto de reformas orientadas pela lógica da fragmentação dos direitos e do resgate de princípios conservadores e liberais, que se manifestam a partir da mudança do modelo de regulação do Estado, que passa a assegurar o workfare em detrimento do welfare. Dentre o amplo conjunto dessas ações, que reverberam nas diferentes esferas da vida social, destacam-se as medidas de ativação para o trabalho, que passam a ser recomendadas por organismos internacionais, em contraposição às denominadas medidas passivas $^{3}$, consideradas ineficazes diante da expansão crescente do desemprego e da pobreza.

As medidas de ativação se apresentam na atual conjuntura como um reforço à lógica do workfare e podem se relacionar com a política de assistência social, na medida em que existe a expansão da concepção de que o bem-estar deve ser provido pelo próprio indivíduo por meio do trabalho assalariado, sem depender ou precisar de intervenção estatal. Nesse sentido, há o resgate da relação histórica e contraditória entre trabalho e assistência, que coloca em destaque os velhos princípios liberais de caráter moral com a segmentação entre aqueles considerados merecedores de assistência e os não merecedores. Diante dessa conjuntura, a assistência social passa a se situar num limbo, entre a garantia dos direitos de cidadania e a destituição dos mesmos, a partir do momento em que passa a ser identificada como uma porta de saída da população pobre, gerando uma ideia distorcida de seu verdadeiro conteúdo e objetivo.

Com isso, é fundamental uma investigação mais aprofundada das características assumidas pela política de assistência social a partir da mudança do papel do Estado capitalista com a transição do welfare para o workfare. A necessidade de uma análise desse tipo no contexto brasileiro também pode ser pautada pela crescente propagação da ideia de inclusão produtiva da população considerada mais pobre, e da relação desta com a assistência social, que passa a ser vista como uma política que deve promover a autonomia e fortalecer as capacidades

\footnotetext{
${ }^{3}$ As medidas passivas são definidas como aquelas que visam assegurar algum tipo de renda durante o período de desemprego.
} 
dos indivíduos, por meio de programas, projetos, benefícios e serviços específicos que garantam, de forma direta ou indireta o acesso ao mercado de trabalho.

A escolha do PRONATEC - BSM como estudo de caso justifica-se pelo entendimento de que o programa expressa no contexto brasileiro a expansão das medidas de ativação destinadas à população que recebe algum tipo de benefício de transferência de renda e está em situação de pobreza. Além disso, o PRONATEC - BSM denota como a política de assistência social vem incorporando a lógica do workfare, por meio da denominada inclusão produtiva, que carrega o ideário de que é preciso promover a autonomia dos usuários, por meio de ações de qualificação profissional, capacitação, dentre outros.

\section{METODOLOGIA}

\section{Método}

Neste trabalho, entende-se que o método não é um conjunto de regras definidas, escolhidas de acordo com objetivos determinados, para assim adequar-se ao objeto investigado. Explicar o que é o método a partir dessa análise seria reduzir e igualar o método aos procedimentos metodológicos de pesquisa. Ao analisar o método de Marx, Netto (2009) afirma que é a dinâmica própria e a estrutura do objeto que irão definir os procedimentos de pesquisa. Portanto, o método para Marx implica no posicionamento do pesquisador frente ao objeto, para assim apreender as suas variadas determinações.

O método investigativo marxiano parte de tudo o que existe, ou seja, da realidade concreta e das diversas descrições de experimentação dessa realidade. Harvey (2013) denomina como método de descenso, pois se inicia da realidade imediata, isto é, do que é aparente, para que se busque conceitos mais profundos e fundamentais, e uma vez munidos desses conceitos, realiza-se então o caminho de volta à superfície, e assim é revelado aquilo que está além da aparência. Dessa forma, entende-se que deve ser realizada uma apreensão da essência do objeto, pois é preciso reunir o máximo de conhecimentos possíveis, analisar criticamente e revisar, para que assim o objeto seja apreendido como processo, fazendo com que sua estrutura e dinâmica fiquem claras (NETTO, 2009).

Marx resgatou o método dialético de análise do real, e relacionou tal método com a teoria de Hegel, porém, inverteu a lógica idealista hegeliana e a diferenciou a partir do materialismo. O materialismo construído a partir das análises marxianas baseia-se na ideia de que o mundo exterior existe independente da consciência, com isso, a matéria é uma categoria 
que demonstra a realidade concreta, que existe independente do homem e suas sensações (RICHARDSON, 2010). Nesse sentido, a dialética se ocupa da investigação de contradições da realidade, pois segundo Netto (2009), é o caráter contraditório das totalidades que compõem a totalidade inclusiva e macroscópica ${ }^{4}$, que conferem o caráter dinâmico e de movimento desta.

A escolha desse posicionamento justifica-se pelo entendimento, de que o materialismo dialético é o único método capaz de proporcionar uma análise crítica da realidade, a partir de suas contradições, e da perspectiva de totalidade, desvendando aquilo que é aparente, e promovendo o entendimento do objeto de pesquisa de maneira mais profunda. Além disso, a opção por esse método se baseia na compreensão de que a política social possui um caráter contraditório, que se expressa pelo conflito de classes na sociedade e pelo fato desta nem sempre ser benéfica aos seus destinatários (PEREIRA-PEREIRA, 2008).

\section{Procedimentos Metodológicos}

Os procedimentos metodológicos podem ser compreendidos como o conjunto de técnicas e instrumentos que permitem conhecer e investigar a realidade concreta e o objeto de estudo proposto, a partir da articulação entre conteúdo, pensamento e existência (MINAYO, 1994). A pesquisa realizada é do tipo documental e utiliza o estudo de caso, que, segundo afirma YIN (2015), propicia a compreensão do objeto investigado em profundidade, pressupondo uma minuciosa revisão de literatura.

Haja vista o objetivo desta dissertação, que é analisar as contradições, concepções e tendências presentes na política de assistência social brasileira, que possam estar relacionadas com a lógica do workfare (bem-estar em troca de trabalho) e de mecanismos de ativação de seus demandantes, foi escolhido como objeto de estudo de caso o PRONATEC-BSM. Este programa foi escolhido, tendo em vista sua particularidade, isto é, por ser um programa de qualificação profissional e acesso ao trabalho, cuja operacionalização e concepção estão diretamente relacionadas com a política de assistência social. Devido ao escopo da pesquisa realizada, a análise dos dados do PRONATEC - BSM privilegiou a abordagem relacionada aos destinatários do Programa Bolsa Família $(\mathrm{PBF})^{5}$ e aqueles inscritos ou em processo de inscrição

\footnotetext{
${ }^{4}$ Importante esclarecer que não se entende a totalidade constituída por partes integradas e funcionais. A categoria totalidade é entendida de acordo com o que Netto (2009) descreve: como totalidade inclusiva e macroscópica, de maior complexidade, formada de outras totalidades menos complexas.

${ }^{5}$ O Programa Bolsa Família (PBF) foi criado no ano de 2003, durante o governo Lula, com o objetivo de unificar programas existentes até então. Atualmente, o PBF é destinado às famílias consideradas em situação de extrema pobreza (com renda per capita mensal de até R \$85) e famílias em situação de pobreza (com renda per capita mensal
} 
no CadÚnico, não abordando, portanto, informações sobre a inclusão de beneficiários do Benefício de Prestação Continuada (BPC).

Devido ao caráter documental da pesquisa, foram utilizadas fontes secundárias, selecionadas de acordo com quatro princípios básicos, apontados por Richardson (2010): a) exaustividade, ou seja, levantamento de todo material passível de utilização; b) representatividade, que pode ser definida como a importância de um documento, em comparação aos demais; c) homogeneidade, pois a seleção deve obedecer a critérios claros e específicos; d) e adequação, que significa que os documentos selecionados devem proporcionar informações adequadas com o objetivo e cumprimento da pesquisa.

Dessa forma, a partir dos critérios mencionados, foram utilizados os seguintes documentos como fonte de dados:

- Portarias, leis, decretos, relatórios e avaliações do órgão federal responsável pela política de assistência social - Ministério do Desenvolvimento Social e Agrário (MDSA);

- Informações do Censo SUAS;

- Informações disponíveis no sítio eletrônico da Secretaria de Avaliação e Gestão da Informação (SAGI/MDSA);

Com base em Flick (2009) buscou-se analisar os documentos quanto ao objetivo e intencionalidade que foi elaborado. Além disso, conforme definido por Boschetti (2009), ao discutir o tema da análise de políticas, programas e projetos sociais, foi utilizado como elemento empírico de análise dos dados, a configuração e abrangência dos direitos assegurados pelo PRONATEC - BSM em sua relação com a política de assistência social, buscando identificar as contradições, concepções e tendências, que possam estar relacionadas com a lógica do workfare.

Além disso, foram utilizados os seguintes indicadores ${ }^{6}$ ao longo da análise: a) Natureza e tipo de direitos e benefícios implementados; b) Abrangência; c) Critérios de acesso e permanência; d) Formas e mecanismo de articulação com outras políticas, em especial com políticas de trabalho e educação; e) Características da ativação para o trabalho; que contempla a motivação política, a capacidade de inclusão no mercado de trabalho, a eficácia frente à

de até $\mathrm{R} \$ 170)$. O valor do benefício varia de acordo com a composição de cada família e o repasse é circunscrito ao cumprimento de condicionalidades nas áreas de saúde e educação.

${ }^{6}$ Apesar da quantidade de indicadores utilizados nesta dissertação, destaca-se que esses não foram usados de maneira indiscriminada e, tampouco, por seu caráter puramente quantitativo, mas sim, no sentido de possibilitar e aprofundar a análise qualitativa sobre a política de assistência social e, principalmente, no estudo de caso do PRONATEC - BSM, evidenciando o caráter focalizado da referida política 
pobreza e o nível de sanção ao participante, que foi um indicador criado a partir do trabalho realizado por Eransus (2005), ao analisar as medidas de ativação em outros países.

No que concerne a organização desta dissertação, foi realizada a seguinte divisão de conteúdo ao longo do trabalho:

No primeiro capítulo foi abordada a discussão sobre o a categoria trabalho, buscando demonstrar sua centralidade no âmbito das Ciências Sociais, a partir de uma discussão crítica e histórica, na qual foram utilizados diferentes autores marxistas. Entende-se que essa discussão é fundamental para compreensão do conteúdo da dissertação, principalmente no que concerne aos temas como workfare, inclusão produtiva, ativação e etc. Este capítulo também contém informações sobre a crise estrutural do capital, suas manifestações fenomênicas ao longo da história e os impactos para o conjunto das políticas sociais.

O preâmbulo do segundo capítulo aborda o desenvolvimento e as características do Estado capitalista, abrangendo a discussão desde os pensadores jusnaturalistas, até aqueles autores contemporâneos. Nesta sequência, é debatida a transição do Estado social para o Estado schumpeteriano, de pró-trabalho, seguida da abordagem acerca do workfare e das políticas de ativação, assim como sua crescente relação com a assistência social.

No capítulo de número três, é discutido o desenvolvimento das políticas sociais no contexto brasileiro. Nele aborda-se sobre a conjuntura política e econômica que conformou o surgimento da seguridade social, assim como suas características na atualidade. Após, é realizada a discussão sobre a política de assistência social, assim como sua contradição histórica com o trabalho.

No quarto e último capítulo é feito um breve resgate histórico da política de trabalho no Brasil, com enfoque nas ações de qualificação profissional. Posteriormente, são apresentados dados sobre a política de assistência social e acerca do PRONATEC - BSM, seguidos da análise e estudo de caso. 


\section{CAPÍTULO 1}

\section{TRABALHO, CRISE DO CAPITAL E OS EFEITOS DELETÉRIOS PARA A POLÍTICA SOCIAL}

\subsection{Trabalho: categoria fundante do ser social}

A categoria trabalho é central para a compreensão da realidade social e das principais transformações da sociedade sob a égide do modo de produção capitalista. A centralidade do trabalho foi defendida por um conjunto de autores clássicos ${ }^{7}$, do campo da sociologia, pertencentes a filiações ideológicas distintas, que de maneira geral compreendiam o trabalho como conceito chave para entender o indivíduo e os aspectos da vida social (CARDOSO, 2011). Apesar da existência de uma gama de autores, é inegável que Marx foi o mais proeminente, e conseguiu dar à categoria trabalho uma dimensão crítica, que vista sob o aspecto não alienante, é compreendida como processo fundante do ser social. Nesse sentido, a partir do pensamento marxiano o trabalho é então concebido como:

\footnotetext{
Um processo de que participam o homem e a natureza, processo em que o ser humano, com sua própria ação, impulsiona, regula e controla seu intercâmbio material com a natureza. Defronta-se com a natureza como uma de suas forças. Põe em movimento as forças naturais de seu corpo, braços e pernas, cabeça e mãos - a fim de apropriar-se dos recursos da natureza, imprimindo-lhes forma útil à vida humana. Atuando assim sobre a natureza externa e modificando-a, ao mesmo tempo modifica sua própria natureza (MARX, 2013, p. 211).
}

A transformação da matéria natural pelo homem ocorre a fim de satisfazer suas necessidades humanas, portanto, o trabalho executado com essa finalidade apresenta um caráter útil, que ao ser transformado em produto/mercadoria apresenta determinado valor de uso, isto, por conseguinte, constitui o que Marx (2013) denomina como processo de trabalho. As necessidades que demandam do indivíduo a transformação da natureza, por meio do trabalho, não são um fim em si mesmas, elas criam novas precisões. Além disso, a realização do trabalho exige um conjunto de conhecimentos, habilidades e instrumentos, isto porque o homem não age diretamente sobre a matéria, há, dessa forma, o imperativo de uma mediação entre o sujeito e o objeto (NETTO e BRAZ, 2011).

\footnotetext{
${ }^{7}$ Dentre os autores da sociologia clássica destacam-se Hegel, Durkheim, Weber e Marx.
} 
O trabalho então se configura em dois planos imanentes, segundo afirmam Netto e Braz (2011). O primeiro é caracterizado pela objetividade, resultante da ação e transformação da matéria pelo homem. E o segundo plano é marcado pelo aspecto subjetivo, pois há uma prefiguração, isto é, há uma atividade considerada teleologicamente direcionada, imaginada no âmbito intelectual como um objetivo, finalidade, antes mesmo de ser colocada em prática ou executada. Marx (2013, p. 211) ilustra a questão da teleologia na seguinte passagem:

O que distingue o pior arquiteto da melhor abelha é que ele figura na mente sua construção antes de transforma-la em realidade. No fim do processo de trabalho aparece um resultado que já existiria antes idealmente na imaginação do trabalhador. Ele não transforma apenas o material sobre o qual opera; ele imprime ao material o projeto que tinha conscientemente em mira, o qual constitui lei determinante do seu modo de operar e ao qual tem de subordinar sua vontade.

É, portanto, a teleologia que distingue o homem dos outros animais. Engels (1999), no artigo Sobre o Papel do Trabalho na Transformação do Macaco em Homem, realiza uma análise da função do trabalho como determinante na formação da sociedade humana, tendo em vista que o homem é historicamente transformado por meio do trabalho, pois a medida em que modifica a natureza, é também modificado por ela, tornando-se um ser social. Deste modo, o trabalho possui caráter coletivo, sendo considerado a objetivação primeira e intrínseca do ser social, e, consequentemente, quanto mais se desenvolve o ser social, mais complexas e variadas tornam-se suas objetivações, alcançando cada vez mais o plano das ideias (NETTO e BRAZ, 2011).

Nesse sentido, Lukács (2013) em sua profunda análise da ontologia do ser social, afirma:

Somente o trabalho tem, como sua essência ontológica, um claro caráter de transição: ele é, essencialmente, uma inter-relação entre homem (sociedade) e natureza, tanto inorgânica (ferramenta, matéria-prima, objeto do trabalho etc.) como orgânica, inter-relação que pode figurar em pontos determinados da cadeia a que nos referimos, mas antes de tudo assinala a transição, no homem que trabalha, do ser meramente biológico ao ser social [...]. No trabalho estão contidas in nuce todas as determinações que, como veremos, constituem a essência do novo no ser social. Desse modo, o trabalho pode ser considerado o fenômeno originário, o modelo do ser social (LUKÁCS, 2013, p. 35).

O autor assevera ainda que o trabalho é o modelo da práxis social, porém, não se limita a apenas ele, mas também inclui o conjunto de todas as objetivações humanas (LUKÁCS, 2013). Dessa forma, situada a partir do desenvolvimento histórico, a práxis, considerada como ato social, é compreendida como a escolha de opções pelo indivíduo social, que realiza suas escolhas com base nos objetivos futuros idealizados (IAMAMOTO, 2012). Ao analisar a teoria 
lukacsiana, Antunes (2009) assevera que a partir das relações entre os seres sociais, quando o objetivo é convencer o outro de fazer determinado ato teleológico, constitui-se assim a chamada práxis social interativa, compreendida por Lukács (2013) como expressão mais desenvolvida e complexa da práxis social, apresentando um distanciamento crescente do trabalho e das ações teleológicas primárias.

Com a então complexificação da sociedade a partir da práxis, surge a divisão social do trabalho, caracterizada como o conjunto de diferentes trabalhos úteis, organizados a partir de uma classificação, de acordo com o tipo, gênero e espécie do trabalho realizado (MARX, 2013). É com o advento da divisão social do trabalho que se estabelece a condição necessária para a existência da produção de mercadorias, que por sua vez, por meio da acumulação, é o que irá reger a produção capitalista. A produção de mercadorias passa a ser então conduzida com base em um único objetivo: a produção de mais-valia, a fim de gerar lucro ao capitalista. É essa lógica que fomenta a produção de mercadorias com valor de troca, ou seja, é o que Marx (2013) descreve como a relação quantitativa entre valor de uso distintos, na medida em que se trocam. Dessa forma, o trabalho perde o seu caráter útil, de trabalho concreto, e, se reduz a trabalho humano abstrato, que gera valor à mercadoria ${ }^{8}$.

De acordo com Marx (2013), a produção na lógica capitalista tem como objetivo gerar mercadorias com valor mais alto do que a soma dos meios de produção e da força de trabalho utilizados no processo, isto é, além de valor de uso, também gerar valor de troca, acrescido de valor excedente, a mais-valia. Nesse sentido, a definição de mais-valia pode ser compreendida em comparação com a produção de valor, a partir da seguinte explicação:

Comparando o processo de produzir valor com o de produzir mais-valia, veremos que o segundo só difere do primeiro por se prolongar além de certo ponto. O processo de produzir valor simplesmente dura até o ponto em que o valor da força de trabalho paga pelo capital é substituído por um equivalente. Ultrapassando esse ponto, o processo de produzir valor torna-se processo de produzir mais-valia (valor excedente) (MARX, 2013, p. 228).

Portanto, com a lei geral de acumulação, o objetivo precípuo do trabalho torna-se a geração de mais-valia, a partir da realização de trabalho excedente que não é pago ao trabalhador, o que enseja ao capitalista a necessidade crescente de extrair uma maior produtividade do trabalho com objetivo de gerar cada vez mais lucro. A produção capitalista é

\footnotetext{
${ }^{8}$ É importante salientar que na mercadoria há, ao mesmo tempo, trabalho concreto e trabalho abstrato. Netto e Braz (2011) afirmam que não se trata de dois trabalhos, mas sim, do mesmo trabalho interpretado segundo perspectivas distintas, isto é, do aspecto do valor de troca, há trabalho abstrato, e sob o prisma do valor de uso, existe trabalho concreto.
} 
essencialmente produção de mais-valia, e o trabalhador imerso nesse processo, não produz para si, mas para o capital (MARX, 1996). O autor afirma ainda que a taxa de mais-valia é a demonstração nítida do grau de exploração da força de trabalho pelo capital, isto porque, uma das formas de extrair mais-valia é através da ampliação da jornada de trabalho, sem a alteração do salário.

Esta questão pode ser facilmente ilustrada na atualidade. Um dos exemplos é a reforma trabalhista francesa, que está sendo proposta pelo presidente François Hollande, que dentre o conjunto de medidas nefastas aos trabalhadores, propõe a extensão da jornada de trabalho. E no Brasil, recentemente, o presidente da Confederação Nacional da Indústria (CNI) defendeu as mudanças previdenciárias e contrarreformas trabalhistas, e ao usar a reforma francesa como exemplo, também propôs o aumento da jornada de trabalho semanal ${ }^{9}$. Segundo Netto e Braz (2011), quando não há condições políticas favoráveis, que garantam a ampliação da jornada de trabalho, os capitalistas buscam outras formas de ampliar a mais-valia, principalmente por meio da redução do trabalho necessário e aumento do trabalho excedente, o que é denominado como mais-valia relativa. Contudo, o que se tem observado, principalmente com os exemplos citados, é a tentativa de expansão da mais-valia absoluta, que é alcançada por meio da extensão da jornada de trabalho, o que, concomitantemente, gera a pauperização absoluta ${ }^{10}$ dos trabalhadores (NETTO e BRAZ, 2011).

Nesse sentido, Marx afirma nos Manuscritos Econômico-Filosóficos:

$\mathrm{O}$ trabalhador se torna tanto mais pobre quanto mais riqueza produz, quanto mais riqueza produz, quanto mais a sua produção aumenta em poder e extensão. $\mathrm{O}$ trabalhador se torna uma mercadoria tão mais barata quanto mais mercadorias cria. Com a valorização do mundo das coisas (Sachenwelt) aumenta em proporção direta a desvalorização do mundo dos homens (Menschenwelt). O trabalho não produz somente mercadorias; ele produz a si mesmo e ao trabalhador como uma mercadoria, e isto na medida em que produz, de fato, mercadoria em geral. (MARX, 2004, p. 80, Grifo do Autor)

O autor aborda a questão da alienação, característica intrínseca do trabalho no modo de produção capitalista, quando há a divisão social do trabalho e da propriedade privada dos meios de produção. Na alienação há o estranhamento, uma vez que, o trabalhador não mais reconhece

\footnotetext{
${ }^{9}$ AGÊNCIA BRASIL - EMPRESA BRASIL DE COMUNICAÇÃO (EBC). Presidente da CNI defende mudanças previdenciárias e nas leis trabalhistas. 08/07/2016. Disponível em http://agenciabrasil.ebc.com.br/economia/noticia/2016-07/cni-defende-carga-de-80-horas-semanais-paratrabalhador-brasileiro. Acesso em 10 de julho de 2016.

${ }^{10}$ Quando há uma piora generalizada das condições de vida e trabalho do proletariado.
} 
o produto de seu trabalho, assim como não reconhece o processo de produção. O trabalho, portanto, passa ser uma mercadoria pertencente ao capitalista, de caráter abstrato e fetichizado, deixando de ter como função precípua a realização humana.

Dessa forma, a partir da análise do processo de acumulação do capital, compreende-se que o próprio trabalhador produz a riqueza na forma de capital, com base no estranhamento, que o domina e explora (MARX, 1984). O processo de produção capitalista reproduz as condições de exploração do trabalhador, uma vez que, quanto maior a exploração da força de trabalho, maior é a geração de mais-valia, que é redirecionada em capital, objetivando o aumento da produção de mercadorias. É, por conseguinte, a transformação de mais-valia em capital, que conforma a reprodução ampliada, que por sua vez, materializa a acumulação de capital (NETTO e BRAZ, 2011). De acordo com Harvey (2013), quando a classe capitalista se apropria da mais-valia e reinvestem-na na produção, há a necessidade do aumento da força de trabalho, em vista disso, a acumulação do capital é sinônimo de crescimento do proletariado.

A acumulação capitalista produz sucessivamente uma população trabalhadora adicional, considerada relativamente supérflua, por isso, o crescimento absoluto do capital e a mudança em sua composição orgânica, está diretamente relacionado a diminuição de seu componente variável, isto é, da força de trabalho absorvida, gerando assim uma superpopulação relativa (MARX, 1984). Essa superpopulação torna-se, deste modo, uma condição da existência da acumulação capitalista, constituindo-se como exército industrial de reserva, que "[...] pertence ao capital de maneira tão absoluta, como se ele o tivesse criado à sua própria custa" (MARX, 1984, p. 200).

O exército industrial de reserva está sempre disponível à exploração do capital, definindo-se como o conjunto de trabalhadores desempregados, que não consegue vender sua força de trabalho. Segundo Netto e Braz (2011), a existência de uma grande quantidade de desempregados permite ao capitalista pressionar a queda do valor dos salários, o que torna o exército industrial de reserva um mecanismo de intensificação da exploração dos trabalhadores e situa o trabalho como a principal forma de sustentação do capital (MÉSZÁROS, 2011).

Marx (1984) divide a superpopulação relativa em três classificações. Primeiro, a superpopulação flutuante, constituída de trabalhadores que estão nas áreas industriais e de mineração, alternando entre o emprego e desemprego. A segunda forma, a superpopulação latente, entendida como o conjunto de trabalhadores de áreas rurais, que no desenvolvimento das relações capitalistas, passam a vender sua força de trabalho nas zonas industriais. E a superpopulação estagnada, definida como a parcela dos trabalhadores de não conseguem 
emprego estável e migram entre diferentes opções. Há também, o denominado lumpemproletariado, considerado pelo autor como o mais profundo sedimento da superpopulação relativa que habita a esfera do pauperismo. Por sua vez, essa camada social é dividida em três categorias: a dos aptos para o trabalho, isto é, vagabundos, criminosos, prostitutas, etc.; aquela constituída por órfãos e crianças indigentes; e os inaptos para o trabalho, definido pelos indivíduos que na divisão social do trabalho, não encontram mais emprego, são aqueles mutilados, enfermos, idosos, viúvas, etc.

Nesse sentido, Marx (1984, p. 209) afirma:

O pauperismo constitui o asilo para inválidos do exército industrial de reserva. Sua produção está incluída na produção da superpopulação relativa, sua necessidade na necessidade dela, e ambos constituem uma condição de existência da produção capitalista e do desenvolvimento da riqueza. [...]. Quanto maiores a riqueza social, o capital em funcionamento, o volume e a energia de seu crescimento, portanto também a grandeza absoluta do proletariado e a força produtiva de seu trabalho, tanto maior o exército industrial de reserva.

Dessa forma, um dos pilares da acumulação capitalista é o aumento do capital constante em detrimento do capital variável, que gera uma força de trabalho excedente, e, portanto, necessária à lógica de produção de riqueza (OLIVEIRA, 2010). Dessa forma, o excedente da população trabalhadora cria um exército industrial de reserva sempre disponível à exploração do capital, o que demonstra que fenômenos como o desemprego e o pauperismo são intrínsecos à lógica da acumulação capitalista, e, portanto, o trabalho situa-se, de maneira contraditória, como a principal forma de sustentação do capital (MÉSZÁROS, 2011).

\subsection{Do fordismo ao toyotismo: trabalho na conjuntura atual}

No início do século XX, a necessidade crescente de acumulação do capital provocou a criação de um novo sistema produtivo, fundamentado numa racionalidade considerada inovadora para a época. O fordismo surge baseado na produção de mercadorias em massa, a partir de uma produção mais homogênea e vertical, cuja principal particularidade é a intensificação das formas de exploração da força de trabalho, que passa a ser organizado em uma escala rígida de produção, de maneira parcelar, com tarefas repetitivas e fragmentadas (ANTUNES, 2009). Nesse sentido, o fordismo consolida a real subsunção do trabalho pelo capital. 
Com a racionalização do processo de trabalho, expressa pela combinação do fordismo com o taylorismo ${ }^{11}$, há uma intensificação da exploração da força de trabalho, a fim de extrair uma quantidade cada vez maior de mais-valia do processo de produção. No fordismo, a maisvalia é extraída de forma predominante, por meio do prolongamento da jornada de trabalho, isto é, em sua forma absoluta. Entretanto, há também a combinação com a mais-valia relativa, caracterizada pelo aumento do trabalho excedente e pela diminuição do trabalho necessário, por meio do incremento de máquinas e equipamentos (ANTUNES, 2009). Devido a estrutura do trabalho parcelado, realizado através da decomposição de tarefas, com um conjunto de ações repetitivas e fragmentadas, o trabalhador não se reconhece e não reconhece o produto de seu trabalho, o que acentua o processo de estranhamento e alienação.

No fordismo, também se destaca o compromisso firmado entre capital e trabalho, com mediação do Estado, denominado como pacto fordista, que se consubstancia com os acordos com trabalhadores em torno dos ganhos de produtividade do trabalho (BEHRING e BOSCHETTI, 2008). Segundo Antunes (2009), esse compromisso surge com a participação de sindicatos e partidos cooptados, com incremento da política keynesiana do Estado social, vigente nos países do capitalismo central. Todavia, esse modelo de produção não durou muito tempo. O fordismo entra em crise no final dos anos 60 , motivado pela estagnação econômica e pela luta de classes. Os trabalhadores passam então a questionar o processo de trabalho fordista, marcado pela exploração intensiva, com técnicas de disciplinamento e coerção.

Como saída para o esgotamento do fordismo e da crise econômica vigente, o processo de acumulação capitalista precisa mais uma vez ser reinventado. $O$ padrão de acumulação flexível surge como salvaguarda do capital, fundamentado na ideia da empresa "enxuta", na produção com tecnologia avançada e com introdução de novas técnicas de gestão da força de trabalho. Passa então a prevalecer uma produção com característica mais flexível (ANTUNES, 2009), na qual ganha destaque o toyotismo, como modelo alternativo ao fordismo.

De acordo com Antunes (2011), o toyotismo é uma forma de organização do trabalho que surge no Japão, e possui como objetivo a produção diversificada, sendo a demanda que determina a quantidade do que será produzido, portanto, a produção é centrada no estoque mínimo. Através do chamado just in time, o toyotismo visa a ampliação e melhor aproveitamento da velocidade no ciclo produtivo, para que exista o aumento da produção de

\footnotetext{
11 De maneira sucinta, o taylorismo, criado pelo engenheiro norte-americano Frederick Taylor, pode ser compreendido como uma forma da administração científica, cujo principal objetivo é o exercício do controle da força de trabalho, sob justificativa da eficiência e do destaque às tarefas no processo de produção.
} 
valores de troca, combinado com a ideia falaciosa da qualidade total das mercadorias (ANTUNES, 2009).

As principais diferenças existentes entre o toyotismo e o fordismo podem ser resumidas da seguinte forma: a produção no toyotismo é variada e heterogênea, em contraposição a padronização do fordismo; o trabalho no toyotismo privilegia a participação coletiva ou em equipe, ao contrário do trabalho parcelado do fordismo; a produção no toyotismo é organizada a partir de um processo produtivo flexível, isto é, que o trabalhador pode operar diferentes máquinas; o toyotismo tem como princípio o melhor aproveitamento possível do tempo de produção, por meio do just in time; e por fim, o toyotismo tem estrutura horizontal, ao contrário da estrutura verticalizada do fordismo (ANTUNES, 2009).

O neoliberalismo propiciou a expansão do toyotismo em escala mundial, com adaptações de suas características originais, mas com manutenção de um denominador comum, a expansão da flexibilização da organização do trabalho, por meio da intensificação da exploração, combinando extração da mais-valia relativa e absoluta, e inserção de maquinário e tecnologias novas. Uma das principais consequências da lógica de produção toyotista são as transformações no mundo do trabalho, no que concerne a expansão da desregulamentação dos direitos do trabalho, precarização e terceirização da força humana, além da fragmentação da classe trabalhadora e da pulverização do sindicalismo (ANTUNES, 2009).

Dessa forma, sob a égide do capital financeiro, o trabalho na atualidade se apresenta cada vez mais de forma precária, flexibilizada e informal. Para Antunes (2005), há uma diminuição do trabalho fabril estável, em contraposição, ao aumento do proletariado terceirizado ou subcontratado. Existe ainda uma expansão da área de serviços, porém, com exclusão de significativa parcela da população do mercado de trabalho, isto é, jovens e idosos. Outra tendência é o aumento da força de trabalho feminino, contudo, com salário menores comparados aos dos homens e com uma jornada de trabalho ampliada, considerando a responsabilidade desigual pelos cuidados dos filhos e das tarefas domésticas.

Apesar das transformações ocorridas nas últimas décadas, é inegável que a categoria trabalho conserva sua centralidade. Essa ideia, contudo, não é universal entre todos os teóricos, dentre os quais destaca-se André Gorz, que em 1980, com o livro Adeus ao Proletariado, defendeu abertamente o fim da centralidade do trabalho, assim como Claus Offe e mais recentemente Habermas, com sua teoria pós-moderna da Teoria da Ação Comunicativa (ANTUNES, 2005). Ao contrário do que afirmam e longe de esgotar o assunto, dada o limite do escopo desta dissertação, é possível afirmar que o trabalho na atualidade, mais do que nunca, 
em sua forma estranhada e alienada, permite a compreensão das relações sociais e da conjuntura atual, demonstrando que permanece uma categoria central.

\subsection{Configurações do trabalho no contexto brasileiro}

No Brasil, as características do trabalho apresentam peculiaridades, haja vista a inserção periférica no capitalismo mundial e as especificidades do desenvolvimento histórico, econômico e social do país. Conforme Pochmann (2012), determinados momentos históricos conformam o desenvolvimento do trabalho no Brasil. O primeiro demarca o período de 1888 a 1930, em que o país tinha a economia baseada na exportação de bens primários, e a força de trabalho era constituída basicamente de trabalhadores do campo e antigos escravos (POCHMANN, 2012). Sabe-se que o escravismo marcou significativamente a constituição da força de trabalho brasileira. De acordo com Behring e Boschetti (2008, p.72) "O maior exemplo desse peso é a condição do trabalho nas relações sociais e no ambiente cultural brasileiros, carregados até hoje de desqualificação, a qual é definidora da relação entre capital e trabalho".

O segundo período histórico definido por Pochmann (2012), refere-se ao ano de 1930 a 1980, isto é, da Revolução de Trinta à Ditadura Militar. De acordo com o autor, o assalariamento passou a ser predominante, devido a expansão da indústria nacional e da inserção do Brasil na economia mundial. Contudo, a industrialização no país se desenvolve marcada pelo fordismo e taylorismo (ANTUNES, 2012), e a expansão do assalariamento se dá por formas desiguais de trabalho e remuneração, o que confere ao mercado de trabalho brasileiro a característica de subdesenvolvimento (POCHMANN, 2012).

Essa configuração também pode ser atribuída ao desenvolvimento do capitalismo brasileiro, que teve uma inserção considerada dependente e periférica frente às economias mundiais. Segundo Marini (1973), a dependência é compreendida como uma relação de subordinação entre países independentes, cujo objetivo é garantir a reprodução da lógica da dependência. "A consequência da dependência não pode ser, portanto, nada mais do que maior dependência" (MARINI, 1973, p. 3). Na exportação de mercadorias, as nações dependentes são desfavorecidas pelo que o autor denomina como troca desigual, e, por isso, compensam a perda de renda pela superexploração da força de trabalho. Para Carcanholo (2013), a superexploração é entendida como um mecanismo de elevação da taxa de mais-valia, por meio do aumento da intensidade de exploração da força de trabalho, através da diminuição dos salários, transformando assim a superexploração em uma forma de compensação que o capitalismo dependente se utiliza para desenvolver-se. 
Dessa forma, as tendências atuais de expansão do desemprego, precarização do trabalho, perda de direitos, dentre outros, têm como reflexo a lógica da superexploração da força de trabalho. Segundo Alves (2014), há na contemporaneidade uma precarização estrutural, que tem como causa a flexibilização do trabalho, por meio da organização toyotista, que gera a contratação salarial precária, a remuneração e a jornada de trabalho flexibilizadas, além de provocar uma agudização do estranhamento, tendo em vista que a lógica do just in time passa a permear não somente o âmbito da produção, mas também as relações sociais, o que o autor denomina como modo de vida just in time.

Ademais, destaca-se a conjuntura política brasileira atual, na qual o governo ilegítimo de Michel Temer pretende realizar mudanças na legislação trabalhista, o que se coloca como uma ofensiva aos direitos duramente conquistados pela classe trabalhadora. Se no Brasil a desregulamentação de direitos já avançava a passos largos, agora o objetivo do presidente interino é flexibilizar cada vez mais, num claro compromisso com o empresariado e com o capital. Somente a organização da classe trabalhadora pode fazer frente à tamanhas ameaças.

\subsection{Crise estrutural do capital e o ataque aos direitos e as políticas sociais}

Dada a sua característica destrutiva, tanto sob a ótica da subjugação do trabalho, por meio da exploração crescente, cuja expressão são as mais diversas iniquidades sociais, como pelo esgotamento dos recursos naturais, o capitalismo vem demonstrando nas últimas décadas sinais claros de seu esgotamento, face as diferentes crises econômicas, as quais muitas vezes são atribuídas equivocadamente como expressões de eventos isolados, frutos de determinações históricas lineares. Essas análises têm em comum uma interpretação superficial, que acabam por escamotear a natureza real do problema: não há capitalismo sem crise. Na realidade, as crises econômicas fazem parte da própria dinâmica do capital, e podem ser consideradas como expressões de uma crise mais ampla, de caráter profundo e estrutural.

Inicialmente, as crises eram mais localizadas e seus efeitos ficavam restritos a determinado país ou região. Contudo, com a expansão do capitalismo, desde o século XIX, as crises econômicas passaram a ter dimensão mundial (NETTO e BRAZ, 2011). A crise sistêmica do capital, assim definida por Mészáros (2009), expressou-se com veemência durante dois momentos históricos distintos: na Europa, no ano de 1873, onde se prolongou uma depressão durante vinte anos; e em 1929, com o denominado crack da Bolsa de Nova York, que abalou a economia mundial e perdurou até o segundo pós-guerra (NETTO, 2012). 
A crise ocorrida durante o ano de 1929 pode ser considerada como uma crise de superprodução, característica que, segundo Mandel (1990), permeia as crises capitalistas em geral e são consequência da própria dinâmica de acumulação do capital. Para o autor, ao contrário das crises pré-capitalistas, que eram marcadas pela baixa produção de valores de uso, as crises capitalistas mais recentes acontecem devido à superprodução de valores de troca. E, nesse sentido, não se deve limitar o entendimento das crises de superprodução à lógica da lei da oferta e da procura, pois neste caso, a superprodução não é causada simplesmente quando há muita oferta no mercado direcionada para uma procura escassa, mas sim, quando há a impossibilidade de venda de mercadorias por preços que garantam a taxa de lucro médio (MANDEL, 1990).

As crises econômicas possuem em sua essência um aspecto contraditório, pois ao mesmo tempo em que demonstram os limites estruturais do capitalismo, também criam condições para retomada de um novo ciclo de aparente crescimento. A partir desse entendimento, podem ser compreendidas como funcionais ao modo de produção capitalista, pois propiciam mecanismos de aparente restauração do sistema, que se complexificam em níveis cada vez mais incertos, e acabam por engendrar as condições de manutenção do capital (NETTO e BRAZ, 2011). Dada a sua característica contraditória, que expõe de maneira mais clara a dinâmica desigual do capitalismo, as crises econômicas atingem de forma diferenciada as classes sociais. São os trabalhadores que sofrem as consequências mais graves. De acordo com Mota (2009), em tempos de crise, a intenção para os capitalistas é sempre manter o poder quando este é ameaçado, e para os trabalhadores, trata-se de uma submissão intensificada, que agrava suas condições materiais de vida e trabalho.

Para garantir a sobrevivência do capitalismo, e assim perpetuar a hegemonia burguesa, é realizado um conjunto de estratégias para administração da crise, que incidem nas relações sociais e abarcam mudanças no papel de intervenção do Estado. Nesse sentido, o Estado acompanha os períodos de estagnação e expansão do capitalismo, e realiza seu papel de reprodução do trabalho e do capital, onde sempre demonstra a primazia do capital sobre o trabalho (BEHRING, 2009).

Com a implementação de medidas para gerenciamento da crise de 1929, o papel do Estado acabou sofrendo uma significativa mudança. O liberalismo ortodoxo foi paulatinamente substituído pelo modelo econômico denominado como keynesiano, associado ao padrão de acumulação fordista. Durante esse período, foram conjugadas estratégias de consumo em massa, a partir da produção de mercadorias com preços mais baixos, implementação de políticas 
de regulação econômica, com objetivo de garantir o aumento dos rendimentos diretos, por meio da geração de empregos, assim como pela via indireta, isto é, pela instituição de políticas sociais (BOSCHETTI, 2010).

Durante o período no qual vigorou o pacto keynesiano ${ }^{12}$, foi estabelecido pelos países capitalistas centrais, com exceção dos Estados Unidos, um padrão de proteção social caracterizado pela garantia do pleno emprego e cobertura universal de serviços sociais, com inspiração beveridgiana ${ }^{13}$, no qual imperava a lógica da cidadania (PEREIRA-PEREIRA, 2010), ainda que esta estivesse orientada a partir de uma perspectiva restrita, a qual Marshall (1967) discorre em sua obra. O Estado com feições keynesianas passa então a ter as seguintes características:

[...] papel ativo na administração macroeconômica, ou seja, na produção e regulação das relações econômicas e sociais. Nessa perspectiva, o bem-estar ainda deve ser buscado no mercado, mas se aceitam intervenções do Estado em áreas econômicas, para garantir a produção, e na área social, sobretudo para as pessoas consideradas incapazes para o trabalho (PEREIRA-PEREIRA, 2008, p. 86).

O desenvolvimento do Estado social ocorreu de maneira contraditória. A ampliação dos direitos e das políticas sociais nesse período não ocorreu de forma condescendente pela burguesia, mas sim devido à luta de classes, associada a necessidade do capital em se manter preservado. Uma das formas de sociabilidade do período foi firmada por meio de um compromisso entre a classe trabalhadora, que tinha garantido pelo Estado ganhos sociais e do trabalho, numa forma de cooptação do movimento operário à dinâmica capitalista (ANTUNES, 2009). Apesar da aparente harmonia, Gough (1982) destaca que os interesses do capital e do trabalho são sempre opostos, portanto, o Estado cumpre sua função estratégica de ser um dos pilares de sustentação do capital, por meio de ações consonantes com o modelo econômico e ideológico vigente neste período.

O modelo fordista-keynesiano e o Estado social passam a ser questionados quando o padrão de crescimento econômico começa a declinar no final da década de 1960, o que Mandel (1990) denominou como "onda longa recessiva", que na realidade expressa mais um fenômeno da crise conjuntural do capital. O discurso liberal é então recuperado e passa a atribuir a crise econômica ao padrão de regulação do Estado keynesiano, de caráter intervencionista. E dessa

\footnotetext{
${ }^{12}$ Foi firmado como uma opção capitalista ao liberalismo, que não conseguiu durante sua vigência garantir bemestar para o conjunto da população, sobretudo após a crise da década de trinta (PEREIRA-PEREIRA, 2010).

${ }^{13}$ Referência ao político William Beveridge, criador do sistema de seguridade social universal na Inglaterra.
} 
forma, é implementado um processo de reestruturação capitalista, cujo objetivo é retomar as altas taxas de lucratividade, atrelado ao resgate dos princípios liberais revestidos de uma nova roupagem: o neoliberalismo.

O programa neoliberal pode ser resumido pela negação da regulação econômica do Estado, pela renúncia das políticas de pleno emprego e pela redução das políticas sociais em prol da regulação do mercado (MOTA, 2011). Trata-se, portanto, de uma verdadeira contrarreforma, uma vez que, a ofensiva do capital resgata os aspectos regressivos liberais, ainda que estes sejam disfarçados de uma nova aparência, o que tem como consequência a agudização das expressões da questão social e, por conseguinte, a piora das condições objetivas de vida da classe trabalhadora (BEHRING, 2008a).

Segundo Netto (2012), o projeto neoliberal pode ser caracterizado pela tríade composta pela flexibilização da produção e das relações de trabalho, somada à desregulamentação dos circuitos financeiros e comerciais e à privatização do patrimônio estatal. Com diferenças nos países do capitalismo central e periférico, o conjunto de medidas neoliberais causou um verdadeiro retrocesso dos direitos até então conquistados pelos trabalhadores (BOSCHETTI, 2010). E para legitimar suas ações e principalmente as consequências negativas destas, o neoliberalismo foi guiado por uma plataforma ideológica própria e seu processo de implementação foi, desde o início, de acordo com Harvey (2013), voltado para restaurar o poder das classes dominantes, com o objetivo de que a crise vigente não afetasse a hegemonia burguesa. Dessa forma, é possível

[...] interpretar a neoliberalização seja como um projeto utópico de realizar um plano teórico de reorganização do capitalismo internacional ou como um projeto político de restabelecimento das condições da acumulação do capital e de restauração do poder das elites econômicas (HARVEY, 2013, p.27).

A liberalização financeira, que já era uma característica marcante na economia dos países desenvolvidos a partir da década de 1980, chega ao Brasil e aos demais países do capitalismo periférico nos anos 1990. De acordo com Salvador (2010), uma das principais estratégias utilizadas pelos países desenvolvidos e pelo Fundo Monetário Internacional (FMI) para estimular os países em desenvolvimento a se engajarem na globalização financeira, foi a elaboração do Consenso de Washington, que impôs uma nova configuração às políticas sociais, que passaram a ser regidas pelo receituário neoliberal. O Consenso de Washington foi uma tática utilizada para promover o ajuste estrutural via liberalização nos países em desenvolvimento. Esses países, ao aderirem a globalização financeira se submeteram então às 
políticas de caráter neoliberal, que foram somadas às medidas de controle da inflação, redução dos gastos públicos, reforma tributária, limitação do Estado à arrecadação, além de outras medidas perniciosas (SALVADOR, 2010).

Os países que adotaram esses ditames, no intuito de se adequarem à economia mundializada, sofrem hoje uma extensa recessão, em que não se vislumbra saída próxima, e que tem como características o desemprego estrutural, taxas de crescimento baixas, precarização do trabalho e baixos salários (BOSCHETTI, 2012a). A lógica por trás da mundialização do capital é impiedosa. Difunde-se a ideia da globalização, que em tese, integraria os países em todo mundo, e assim permitiria uma expansão econômica e cultural dinâmica, sem fronteiras. No entanto, por ser um conceito que carrega um forte teor ideológico, esconde que o mundo é composto por países em situações desiguais, onde existe uma hierarquia clara: quem tem mais, dita as normas, e quem tem menos, apenas obedece (CHESNAIS, 1996).

No contexto brasileiro, os efeitos da crise geraram um vazio político interno e o projeto de desenvolvimento nacional cedeu lugar à financeirização da riqueza, legitimada então pelo Estado capitalista ditatorial, que vigorava naquele período (POCHMANN, 2004). Nesse contexto, as políticas sociais apresentavam um caráter dual de acesso, ou seja, quem podia pagar acessava o mercado privado, e quem não podia recorria aos serviços públicos (BEHRING e BOSCHETTI, 2008). Com o fim da ditadura militar, o processo de abertura democrática culminou na promulgação da Constituição, que segundo Pereira-Pereira (2012), trouxe dispositivos avançados, considerados inéditos no contexto político brasileiro, como a ampliação dos direitos sociais, com destaque à seguridade social, e a responsabilidade estatal na efetivação dos mesmos. Contudo, com o fortalecimento do neoliberalismo no Brasil e a ofensiva das forças conservadoras, tais direitos foram negados por princípio e ainda encontram dificuldades para serem efetivados (PEREIRA-PEREIRA, 2012).

Para Mészáros (2009), as diferentes crises econômicas vividas nas últimas décadas são, na verdade, expressões da crise estrutural do capital, que passou a manifestar-se mais claramente a partir da crise econômica dos anos 1970. O autor afirma que a crise estrutural do capital pode ser considerada cumulativa, endêmica, crônica e permanente. E dada suas características, também foi uma motivadora do questionamento da centralidade da categoria trabalho para o pensamento sociológico. Segundo um conjunto de autores, as transformações sociais, econômicas e políticas da sociedade mostravam que o capitalismo tinha se transformado, e que a busca pela valorização do capital tinha dado lugar a uma forma mais subjetiva no processo produtivo, e, dessa forma, as teorias do pensamento social que davam 
centralidade ao trabalho não poderiam mais explicar essas mudanças (CARDOSO, 2011). Contudo, tais ideias podem ser consideradas questionáveis sob diferentes aspectos. Somente a compreensão crítica da categoria trabalho, a partir de sua centralidade na relação com o modo de produção capitalista, é capaz de explicar as contradições vigentes e a radicalização da exploração dos trabalhadores, e, portanto, que as necessidades do capital são sempre irreconciliáveis e opostas às necessidades humanas (GOUGH, 2003).

Dentre os efeitos da crise do capital destacam-se aqueles referentes ao mundo do trabalho e da reconfiguração do papel do Estado. A transformação profunda vivida nesse período constituiu as bases para a reestruturação produtiva do capital, que foi fortalecida após a expansão do neoliberalismo (ANTUNES, 2012). Segundo o autor, ocorrem as seguintes mudanças na esfera produtiva: a) redução do proletariado fabril; b) aumento do subproletariado fabril e de serviços, por meio do trabalho precarizado; c) crescimento do trabalho feminino no contexto desregulamentado e precarizado; d) exclusão dos jovens e idosos do mercado de trabalho; e) aumento do trabalho infantil; f) expansão do denominado trabalho social combinado, definido por Marx como aquele que os trabalhadores de todo mundo participam do processo produtivo (ANTUNES, 2011).

Outro efeito da crise conjuntural do capital que afeta o mundo do trabalho, e, por sua vez, a própria configuração dos sistemas de proteção social, é o chamado desemprego crônico, assim definido por Mészáros (2009). O padrão atual de desemprego é um indicador do aprofundamento da crise do capitalismo. Esse processo, longe de ser natural, é, na verdade, mais uma expressão da lógica de acumulação, sendo a geração de trabalho excedente necessária para o funcionamento da dinâmica capitalista. Nessa conjuntura, a nova configuração do desemprego não afeta somente os trabalhadores não qualificados, como acontecia anteriormente, mas atinge também o conjunto dos trabalhadores qualificados, abarcando dessa forma a totalidade da força de trabalho (MÉSZÁROS, 2009).

Acerca desse tema, os autores Júnior e Nascimento (2013, p. 30) fazem uma análise do desemprego crônico, a partir das categorias marxianas:

[...] hoje evidenciamos uma ofensiva sob a classe operária em duas frentes (e não apenas nas partes "subdesenvolvidas", mas também nos países capitalistas centrais): por um lado, um desemprego que cresce cronicamente em todos os campos de atividade, mesmo quando disfarçado como "práticas trabalhistas flexíveis" - eufemismo para a política de fragmentação e precarização da força de trabalho; e, por outro lado, uma redução significativa do padrão de vida até mesmo daquela parte da população trabalhadora que se apresenta 
necessária aos requisitos operacionais do sistema produtivo em ocupações de tempo integral.

Nesta conjuntura, chama a atenção a disponibilidade dos países em implementar ações de administração da crise, e, dessa forma, salvar instituições bancárias e empresas da bancarrota utilizando os recursos do fundo público (SALVADOR, 2010). Existe hoje uma tendência do endividamento dos Estados nacionais, sobretudo na Europa, com a implementação de planos de austeridade, que acabam por acarretar um custo social elevado para a população (BEHRING, 2012), além de promoverem o desmantelamento dos princípios orientadores dos sistemas de proteção social. No estudo de Boschetti (2012b), a autora mostra que o desemprego de longa duração associado à redução das prestações sociais causou o agravamento da pobreza e da desigualdade social dos países europeus nos últimos anos e os sistemas de proteção social passaram a ter como principais características a focalização, perda de qualidade dos serviços, redução dos direitos, ampliação do mercado privado e medidas de ativação para o trabalho.

Dessa forma, destaca-se a participação do Estado no sentido de implementar mecanismos de administração da crise, com o objetivo de garantir a continuidade da reprodução ampliada do capital, o que torna o aprofundamento sobre a discussão do papel do Estado capitalista fundamental. 


\section{CAPÍTULO 2}

\section{ESTADO DE WORKFARE E ATIVAÇÃO PARA O TRABALHO: CARACTERÍSTICAS E CONFIGURAÇÃO ATUAL}

\subsection{O Estado capitalista}

Um dos primeiros debates sobre a origem do Estado ocorre no âmbito do jusnaturalismo, corrente teórica dos séculos XVII e XVIII, que fundamenta o corolário liberal, no qual o Estado é considerado um poder que legitima e protege os direitos individuais. Para Thomas Hobbes e John Locke, autores jusnaturalistas, não existe contraposição entre Estado e sociedade civil, mas sim uma substituição de um momento pelo outro, isto é, de um estado de natureza, sem leis e ordem, para o momento político, no qual são estabelecidas normas e um contrato social, em que o Estado é o principal produto (MONTAÑO e DURIGUETTO, 2011).

Nesse entendimento, a sociedade civil ou sociedade política surge a partir da instituição do contrato social, que pelo consenso dos indivíduos, delegam ao Estado a função de coerção para manutenção da ordem estabelecida. Locke baseia sua teoria a partir da ideia de que o fundamento da propriedade privada é o trabalho, e o estabelecimento do contrato social garante a conservação desse direito (MONTAÑO e DURIGUETTO, 2011). O autor naturaliza a existência de pobres e ricos, em função da capacidade de trabalho individual, e não por acaso, suas ideias fundamentam os princípios do Estado liberal e do liberalismo. Ainda sobre os autores jusnaturalistas, Rousseau acredita que a propriedade privada é a causa de todas as desigualdades e que são os interesses do povo que devem governar a sociedade.

$\mathrm{Na}$ tradição marxista, o Estado surge a partir da sociedade civil e expressa suas contradições, portanto, é determinado pelas relações de produção da sociedade e pela correlação de forças existente entre as classes, manifestando assim as relações sociais capitalistas, e sua dependência ao poder econômico e político da burguesia (MONTAÑO e DURIGUETTO, 2011). É celebre a frase do Manifesto do Comunista, no qual Marx e Engels (2007) afirmam que o governo do Estado moderno é um comitê, cujo objetivo é administrar os negócios da burguesia. Nesse sentido, segundo Poulantzas (1979), o Estado sempre constitui as relações de produção, e na reprodução destas, expressa as relações econômicas, políticas e sociais da classe burguesa, legitimando assim a dominação sobre o proletariado, por meio da garantia da propriedade privada. Para o autor, o Estado é compreendido não apenas como um conceito estanque, mas como uma relação social. 
Neste entendimento, o Estado apresenta o caráter de dominação de classe, por isso, para extinção da ordem burguesa, é necessário o fim do Estado, pois este expressa o poder econômico e político da burguesia (MARX e ENGELS, 2007). De acordo com Marx (2010), o fim da sociedade burguesa é condição básica para a emancipação política, o que permite a efetivação da emancipação humana, por meio do fim da propriedade privada, da exploração pelo trabalho e concomitantemente, do Estado. Dessa forma, o autor afirma:

O Estado político pleno constitui, por sua essência, a vida do gênero humano em oposição à sua vida material. Todos os pressupostos dessa vida egoísta continuam subsistindo fora da esfera estatal na sociedade burguesa, só que como qualidades da sociedade burguesa. Onde o Estado político atingiu sua verdadeira forma definitiva, o homem leva uma vida dupla não só mentalmente, na consciência, mas também na realidade, na vida concreta; ele leva uma vida celestial e uma vida terrena, a vida na comunidade política, na qual ele se considera um ente comunitário, e a vida na sociedade burguesa, na qual ele atua como pessoa particular, encara as demais pessoas como meios, degrada a si próprio à condição de meio e se torna um joguete na mão de poderes estranhos a ele. A relação entre o Estado político e a sociedade burguesa é tão espiritualista quanto a relação entre céu e a terra. A antítese entre os dois é a mesma, e o Estado político a supera da mesma maneira que a religião supera a limitação do mundo profano, isto é, sendo igualmente forçado a reconhece-la, produzi-la e deixar-se dominar por ela. $\mathrm{Na}$ sua realidade mais imediata, na sociedade burguesa, o homem é um ente profano. Nesta, onde constitui para si mesmo e para outros um indivíduo real, ele é um fenômeno inverídico. No Estado, em contrapartida, no qual o homem equivale a um ente genérico, ele é o membro imaginário de uma soberania fictícia, tendo sido privado de sua vida individual real e preenchido com uma universidade irreal (MARX, 2010, p. 40).

Outros autores marxistas abordaram a discussão sobre o Estado capitalista. Lenin (2007) ressalta o papel do Estado como mecanismo de repressão, definindo-o como instrumento de exploração da classe oprimida. Para o autor, a existência do Estado é atrelada ao conflito entre as classes, por isso a necessidade do fim da existência destas, assim como do fim da aparelhagem estatal para efetivação da revolução e transição do capitalismo ao comunismo. Para Lenin (2007), a classe operária deve destruir a máquina do Estado, não se contentando apenas em dominá-la.

O conceito de Estado é ampliado em Gramsci (2001), uma vez que, o autor considera que este não é unicamente um aparelho repressivo da burguesia, mas que incorpora outras funções, ainda que preserve suas características precípuas, de coerção e dominação, também agregando a sociedade civil, por meio do consenso (GRAMSCI, 1984). A sociedade civil para Gramsci (1984) faz parte do Estado, da superestrutura, permeada de conflitos de classes, numa 
intensa correlação de forças. De acordo com o autor, para apreender a noção de Estado, é necessário considerar os elementos relacionados à sociedade civil, no sentido de compreender que o Estado é uma junção da sociedade política e da sociedade civil (GRAMSCI, 1984). Destarte, a esfera da sociedade política é que incorpora a função de dominação da classe burguesa.

A origem do Estado é atrelada ao surgimento da propriedade privada, associando-se a distinção entre as esferas privada e pública na sociedade (MANDEL, 1982). Portanto, o Estado é anterior ao capital e suas funções não são diretamente provenientes da lógica de produção. Entretanto, cabe destacar que o Estado burguês se diferencia de todas as formas estatais anteriores, haja vista a especificidade da sociedade burguesa no que concerne à dominação de classe e ao modo de produção capitalista, assim como a separação estre a esfera privada e pública. Nem todas as funções do Estado são superestruturais, nesse sentido, Mandel (1982, p. 333) elenca as três principais funções estatais no capitalismo tardio:

1) Criar as condições gerais de produção que não podem ser asseguradas pelas atividades privadas dos membros da classe dominante; 2) Reprimir qualquer ameaça das classes dominadas ou de frações particulares das classes dominantes ao modo de produção corrente através do Exército, da polícia, do sistema judiciário e penitenciário; 3) Integrar as classes dominadas, garantir que a ideologia da sociedade continue sendo a da classe dominante e, em consequência, que as classes exploradas aceitem sua própria exploração sem o exercício direito da repressão contra elas (porque acreditam que isso é inevitável, ou que é "dos males o menor", ou a "vontade suprema", ou porque nem percebem a exploração).

Dessa forma, ficam claras as funções precípuas do Estado capitalista, isto é, a dominação e coerção, assim como o consenso, necessário a manutenção da ordem estabelecida. A partir da teoria gramsciniana, Jessop (2008), assim como Poulantzas (1979), considera o Estado uma relação social. Deste modo, para o autor o Estado pode ser definido como o conjunto de instituições, organizações e atividades reguladas, reunidas de forma estratégica com o intuito de tomada de decisões. O poder estatal pressupõe uma correlação de forças, isto é, uma relação de poder, mediada por um conjunto institucional organizado (JESSOP, 2008).

\subsection{Do Estado Social ao Estado schumpeteriano de workfare}

O Estado social surge nos países do capitalismo central, no final do século XIX, em decorrência dos conflitos motivados pela industrialização e representa um modelo de 
intervenção estatal na economia, com expansão dos direitos sociais e materialização de políticas sociais organizadas em um sistema de proteção social (PEREIRA-PEREIRA, 2008). Anteriormente à expansão do Estado social, o Estado de caráter liberal era o padrão vigente e dominante, cujo principal mote foi a garantia da propriedade privada e expansão dos direitos individuais clássicos, defendidos pelos principais pensadores jusnaturalistas. Segundo Behring e Boschetti (2008), não há uma ruptura clara e linear entre o Estado liberal e o Estado social, ocorrendo na realidade uma modificação nas características do Estado, que não esmaeceu totalmente os princípios liberais, mas que os abrandou, devido a substituição por orientações de feição socialdemocratas num contexto de intensa luta de classes.

De acordo com Pierson (1991), as principais características que conformam o Estado social podem ser resumidas como a expansão do gasto nas áreas sociais, a ampliação da definição de cidadania, que deixa de ter caráter restrito, isto é, limitada aos direitos civis, e o surgimento do seguro social. Dessa forma, a criação de seguros obrigatórios por Bismarck, na Alemanha do final do século XIX, pode ser considerado um dos fatos históricos que demarcaram o surgimento do Estado social. Contudo, é importante ressaltar que as reformas bismarckianas, apesar de aparentarem ser inovadoras, apresentam caráter conservador e limitado, ou seja, circunscrito aqueles que trabalhavam, o que, portanto, não coadunava com as ideias socialdemocratas, que surgiam naquela época (PEREIRA-PEREIRA, 2008).

No século XX, o Estado social capitalista adquire novas feições e se consolida no segundo pós-guerra. Devido à crise de 1929, o aparato estatal passa a assumir atribuições anticíclicas, de administração da crise, com o objetivo de salvaguardar o capital. Surge então o keynesianismo, que confere ao Estado a tarefa de intervenção e regulação da economia, com objetivo de afiançar o pleno emprego e o consumo de massas, assim como a ampliação de medidas de bem-estar, com vistas à reprodução da força de trabalho. Soma-se a esta conjuntura, a adoção da concepção de seguridade social ampliada na Inglaterra, a partir do Relatório sobre Seguro Social e Serviços Afins, conhecido como O Plano Beveridge, elaborado no ano de 1942. Nele, a seguridade social, é considerada um componente do Estado social, além de representar a ampliação da ideia de cidadania, até então circunscrita às ações limitadas bismarckianas.

Com o sistema de produção fordista e expansão do capital imperialista, a intervenção estatal na economia é direcionada para a garantia das altas taxas de lucros, cuja finalidade é a preservação das condições de produção e acumulação, assim como, com relação ao controle e garantia de reprodução da força de trabalho, por meio da instituição de políticas sociais de caráter ampliado (BRAZ e NETTO, 2011). O denominado pacto fordista girava em torno de 
acordos e de ganhos de produtividade pelos trabalhadores e segundo Behring e Boschetti (2008), o fordismo foi muito além de um modo de produção, mas também uma forma de regulação das relações sociais numa conjuntura política e econômica historicamente determinada.

Cabe destacar que o entendimento acerca do Estado social deve levar em conta seus aspectos contraditórios, isto é, este não deve ser analisado a partir de uma visão que PereiraPereira (2008) denomina como welfarista, de que o Estado produz somente bem-estar por meio de políticas sociais, mas sim que o Estado é eminentemente capitalista, o que atribui ao instrumento estatal também o papel de garantir a reprodução ampliada do capital e manter a ordem estabelecida - o próprio capitalismo. Nesse sentido, para Boschetti (2016), a denominação Estado social não quer dizer que o Estado adquire uma característica anticapitalista ou de intenção de socialização dos ganhos, mas que a perspectiva que deve ser utilizada é da contradição, tendo em vista a existência da luta de classes.

No final da década de 1970, com a estagnação do fordismo e mais uma crise econômica mundial, as características que conformavam o Estado social passam a dar lugar ao ressurgimento do corolário liberal, agora revisitado pelo neoliberalismo, cujo modelo econômico torna-se o monetarismo. Com isso, são realizadas um conjunto de contrarreformas, incitadas principalmente pelos organismos multilaterais mundiais, que materializam seu receituário neoliberal através do Consenso de Washington, exigindo assim que os mais diversos países realizem ajustes fiscais, privatizações, flexibilização trabalhista, diminuição do Estado e, fragmentação e desmonte das políticas sociais (PEREIRA-PEREIRA, 2010).

Com as mudanças estruturais, o Estado capitalista diminui sua intervenção na economia e deixa de garantir a cidadania ampliada, por meio de políticas sociais universais, para ter caráter mínimo. Contudo, é importante frisar que essa nova configuração estatal não significou a completa ausência de políticas sociais, mas que estas sofreram retrocessos significativos, se comparado com o período anterior, quando vigorava o fordismo-keynesianismo do Estado social. Com a vigência do monetarismo, foram resgatados os preceitos schumpeterianos, que serviram como baliza para o modelo neoliberal prevalecente (PEREIRA-PEREIRA, 2009).

O Estado de viés schumpeteriano é concebido a partir da lógica da inovação produtiva e do empreendedorismo, com vistas a potencializar a competitividade. Dessa forma, a atuação estatal passa a ser direcionada à garantia de incentivos à esfera privada, além da intervenção na reprodução da força de trabalho, com objetivo de garantir a flexibilização e a qualificação de novas tecnologias para beneficiar empresas (ARIENTI, 2003). Segundo Jessop (2008), a 
competividade estrutural schumpeteriana promove a subordinação da política social às exigências de competitividade econômica, o que implica uma mudança significativa na natureza do Estado e seu papel na reprodução social.

Dessa forma, a política social passa a ser direcionada ao mercado, no sentido de adaptar e promover a reprodução da força de trabalho para a flexibilização da produção (ARIENTI, 2003). Devido a este conjunto de mudanças estruturais, o Estado schumpeteriano é então denominado como de pró-trabalho, cujo conjunto de políticas sociais passa a guiar-se pelo mérito, ou seja, a garantir prestações sociais em troca de trabalho, e, assim, caracterizar a passagem do Estado social, que garantia o welfare, para o Estado do Trabalho ou Labor, que passa a ofertar o workfare (PEREIRA-PEREIRA, 2009).

\subsection{Workfare: a lógica do trabalho como obrigação ou contrapartida}

Em decorrência das mudanças estruturais causadas pelo neoliberalismo, que teve nos preceitos schumpeterianos um de seus arrimos, é observado a partir da década de 1990 uma transformação no papel do Estado, no que concerne a uma maior ênfase nas políticas ativas sobre o mercado de trabalho. Segundo Jessop (2008), são criadas novos regimes, rotinas e fundamentos na regulação do trabalho, com objetivo de substituir os marcos do Estado social, supostamente em crise de acordo com os críticos neoliberais, para um regime fundamentado no estímulo e na obrigação ao trabalho, marcado pela necessidade de contrapartida às prestações sociais, isto é, um regime de workfare.

Nesse sentido, o termo workfare surge em oposição ao welfare, e designa um conjunto de políticas que não garantem incentivos e direitos ao trabalho, ao contrário do que os ideólogos desse construto defendem, mas colocam aos trabalhadores a obrigatoriedade em se empregar (GOUGH, 2003). De acordo com Márquez (2008), a palavra workfare provem da contração da expressão welfare to work, utilizada para designar a transição do regime de bem-estar social, no qual são garantidos direitos de cidadania, para o regime de trabalho ou pró-trabalho, que impõe o exercício do trabalho como obrigação e condição para acesso às políticas sociais.

Há um extenso debate sobre o conceito de workfare, portanto, sua definição varia, ainda que minimamente, de acordo com os diferentes autores que abordam a temática. Para Eransus (2005), o workfare é caracterizado pelas políticas que possuem como orientação acabar com a dependência da assistência social. A autora considera que o workfare tem um forte caráter de obrigatoriedade e de responsabilização dos indivíduos pela própria inserção no mercado de trabalho (ERANSUS, 2005). Com uma definição semelhante, Márquez (2008), afirma que o 
workfare refere-se a um conjunto de medidas de inserção laboral, no qual se destacam a obrigação em conseguir um trabalho para poder receber qualquer tipo de prestação social. Para o autor, "Quanto mais rápido é o retorno ao mercado de trabalho, mais exitosa são as medidas da filosofia do workfare” (MÁRQUEZ, 2008, p. 144, tradução nossa).

Nesse sentido, Wacquant (2012) define o workfare como o conjunto de programas de assistência social voltado aos mais pobres, cujo recebimento de qualquer benefício é condicionado às estratégias de emprego, logo, o workfare se opõe ao welfare, tendo em vista que o direito à assistência não pode ser questionado. $\mathrm{O}$ autor atribui o surgimento do workfare ao contexto estadunidense da década de 1970, tendo o Consenso de Washington um papel fundamental na reorganização do papel do Estado, que passou a ter um forte caráter disciplinador e punitivo, sendo sua ação workfareana voltada para desregulamentação e flexibilização do mercado de trabalho.

A lógica de obrigatoriedade ao trabalho em troca de proteção social presente nas políticas de workfare, deixa claro o aspecto punitivo e de julgamento moral ao culpabilizar os mais pobres por sua situação (LAVILLE, 2000). Complementar a essa questão, situa-se a concepção amplamente difundida da criminalização da pobreza, que passa a ser atribuída à esfera individual, e, por sua vez, a assistência pública é condicionada ao trabalho, com critérios excludentes e vexatórios. Este ideário ressalta o caráter penal e policial do Estado, que segundo Moser (2011), passa a prezar por ações de controle, vigilância e pelo bom uso das prestações sociais.

Dessa forma, depreende-se que o ponto comum da definição de workfare abordada pelos autores citados, refere-se à obrigatoriedade ao trabalho como contrapartida ao recebimento de qualquer tipo de prestação social. Também chama a atenção o fato de que, em geral, a exigência da inserção laboral é mais frequentemente associada à política pública de assistência social, que possui caráter não contributivo. A hipótese dessa associação pode ser atribuída à contradição histórica existente entre trabalho e assistência, marcada pelo ideário liberal de que o bem-estar deve ser alcançado unicamente através do trabalho. Destarte, nesta dissertação parte-se da concepção ampliada de workfare, a qual Barbosa (2013) determina como o entendimento de qualquer política baseada em punições, assim como àquelas que apresentam motivação subjetiva para o trabalho e outros serviços públicos.

\subsection{Flexiseguridade e ativação para o trabalho}


No contexto do workfare destacam-se duas tendências nocivas no âmbito do trabalho apontados por Jessop (2008). A primeira é denominada flexiexploração e faz referência ao conjunto de medidas trabalhistas neoliberais, que resultam na flexibilidade e insegurança no emprego, somadas a uma maior coação para que o desempregado encontre um trabalho. A segunda é a flexiseguridade, termo proveniente da palavra inglesa flexicurity, que designa o conjunto de políticas que tornam o mercado de trabalho mais flexível, ao mesmo tempo que oferecem uma rede de seguridade social e trabalhista aos que possuem trabalho, assim como para aqueles que não o têm (JESSOP, 2008).

Segundo Lorenzo (2008), a flexiseguridade combina seguridade social com um conjunto de estratégias voltadas à promoção da competitividade, por meio da flexibilização, isto é, mudanças na legislação trabalhista, que concedem vantagens aos empregadores, com objetivo de facilitar a contratação e demissão, ao mesmo tempo em que retira direitos dos trabalhadores. $\mathrm{O}$ autor afirma ainda que as estratégias de flexiseguridade abrangem dispositivos contratuais frágeis, medidas de ativação para inserção no mercado de trabalho e ações de aprendizagem e qualificação permanentes (LORENZO, 2008). O exemplo dessa tendência é citado por Abrahamson (2009), que ao abordar o modelo da flexiseguridade na Dinamarca, menciona o destaque que vem sendo dado às políticas de ativação e qualificação profissional, o que demonstra que até os países nórdicos, que historicamente garantiram direitos sociais mais abrangentes, vem cedendo lugar à lógica do workfare.

Nesse sentido, as medidas de ativação podem ser consideradas como uma expressão da ofensiva do capital, direcionada aos sistemas de proteção social nas últimas décadas, que passam a se orientar pelos princípios do workfare, com o resgate de orientações liberais, baseadas na ideia central de que não existe melhor fonte de bem-estar do que o trabalho. Como demonstra Pereira-Pereira (2013), essa relação entre proteção social e trabalho é histórica, intrínseca às sociedades divididas em classes, e tem como mote a prevalência das necessidades do capital em detrimento das necessidades humanas, e demonstra que quanto mais a proteção social se vincula ao trabalho, mais ela é valorizada e vista com bons olhos pela sociedade. Percebe-se então que as medidas de ativação não surgem por acaso, estão situadas numa conjuntura capitalista específica e não apresentam tendências completamente novas, que na realidade, podem ser consideradas como revisitadas.

A origem do termo ativação surge na Suécia, durante a década de 50 do século XX, e faz referência ao conjunto de políticas de orientação macroeconômica direcionada para facilitar o acesso de todos os cidadãos ao mercado de trabalho (ERANSUS, 2005). Com o passar das 
décadas e devido às mudanças estruturais de ordem política e econômica, as políticas de ativação passam a ganhar destaque e a ter um sentido diverso do original. Diante da conjuntura de desemprego estrutural, inerente e funcional ao modo de produção capitalista, somado às ideias neoliberais vigentes, são consolidados os principais argumentos que fundamentaram a expansão da ativação.

A primeira premissa defendida pelos teóricos do neoliberalismo refere-se à necessidade de limitação dos gastos do Estado, tendo em vista os níveis elevados de desemprego de longa duração, o que aumentaria a quantidade de prestações sociais e o seu período de concessão. $\mathrm{O}$ segundo argumento utilizado é de que as políticas compensatórias do Estado social falham na inserção no mercado de trabalho. E o terceiro pretexto utilizado faz referência à ideia de que as prestações sociais causam dependência, devendo o indivíduo buscar a satisfação de suas necessidades sociais no mercado (HESPANHA e MATOS, 2000).

De acordo com Jessop (2008), a expansão das políticas de ativação pelos diferentes países, é resultante do reordenamento da relação entre política econômica e política social no capitalismo tardio. $\mathrm{O}$ autor assevera que o Estado social passa a ser considerado pela direita como uma causa da rigidez do mercado de trabalho e do aumento dos custos de produção, o que levou a exigência de mudanças no padrão de regulação, que promovessem uma maior flexibilização do trabalho e de redução dos custos. Dessa forma, juntamente com a ampliação das políticas de ativação, surge a crescente relação com as prestações por desemprego e com a assistência social (JESSOP, 2008).

No que concerne à sua conceituação, as políticas de ativação podem ser entendidas como estratégias de inserção laboral dos indivíduos que se encontram fora do mercado de trabalho, e, quando há uma relação entre proteção social e políticas de emprego (ERANSUS, 2005). Para Hespanha e Matos (2000), as políticas de ativação são orientadas como um direito de inserção, baseando-se em ações personalizadas que conseguem promover o acesso ao emprego e remediar situações denominadas como de exclusão.

A concepção adotada pelos autores pode ser considerada limitada, ao desconsiderar que as tendências atuais apontam que as políticas de ativação assumem em determinados contextos um caráter anti-social, isto é, apresentam aspectos coercitivos e punitivos, ao estabelecerem a obrigatoriedade de inserção daqueles que recebem prestações sociais. Além disso, é questionável a efetividade das políticas de ativação no que concerne a inserção de trabalhadores no mercado de trabalho, como também, da saída dos mesmos da situação de desigualdade, isto porque no contexto de flexibilização, é preponderante o cenário de precarização e desemprego. 
Essa ideia pode ser corroborada pela tendência europeia dos "trabalhadores pobres", definida pelo conjunto de trabalhadores com baixo nível de qualificação, que recebem baixos salários e que estão sujeitos ao ciclo perverso: emprego - desemprego - desproteção - desqualificação ativação (LORENZO, 2008).

As políticas de ativação surgem para substituir as medidas de proteção econômica consideradas como "passivas", avaliadas como ineficientes e não flexíveis, pois não incentivam o retorno ao mercado de trabalho e freiam a criação de empregos, ao incrementar medidas elaboradas para estimular a inserção ao mercado de trabalho dos desempregados, entendidas então como "ativas", e compreendidas como positivas para a economia (DURANA e ERANSUS, 2007). A expansão das políticas ativas, em detrimento daquelas entendidas como passivas, passa a acontecer com maior ênfase, sobretudo nos países europeus, a partir da década de 1990, quando a Cúpula da União Europeia sobre Emprego determina que os Estados membros se comprometam a promover com maior intensidade as medidas de ativação.

Não há um consenso formado sobre o conceito de ativação. Existe uma heterogeneidade de práticas ativadoras nos países, que diferem com relação aos seus objetivos, destinatários, resultados e denominações (ERANSUS, 2005). Portanto, é preciso utilizar o termo com cautela, para que não seja compreendido como um conceito estanque, isto é, que designe somente um tipo de prática, sem diferenciações e especificidades de uma realidade para outra. Para Jessop (2008), as políticas de ativação se diferenciam de acordo com a realidade de cada país, com variações com relação a sua obrigatoriedade e aos níveis de sanção.

Segundo Boschetti (2012b), as políticas de ativação podem ser divididas pela seguinte lógica: estabelecem subsídios para tornar o trabalho mais lucrativo para as empresas; exigem a realização de contrapartidas ao seguro-desemprego e às prestações assistenciais. Jessop (2008, p. 192) também destaca três aspectos fundamentais das políticas de ativação, quais sejam:

[...] se dirigem a aumentar a flexibilidade do mercado de trabalho; tentam melhorar a capacidade de obtenção de emprego pelos trabalhadores e os transformam em sujeitos empreendedores em um mundo pós-fordista; se orientam de maneira crescente a uma economia baseada no conhecimento, na qualificação e na aprendizagem ao longo de toda a vida. (Tradução nossa).

Sob tais aspectos, percebe-se que as medidas de ativação favorecem o capital e têm destinado aos trabalhadores cada vez mais a responsabilidade pelo seu próprio bem-estar, que deve ser garantido por meio do trabalho assalariado precário e flexibilizado. Essa lógica tem sido propagada nas últimas décadas pelos organismos internacionais, dentre os quais se destacam o Banco Mundial, Organizações das Nações Unidas (ONU), Organização para 
Cooperação e Desenvolvimento Econômico (OCDE), e União Europeia (UE), que passaram a recomendar as políticas de ativação para melhoria da qualificação dos trabalhadores, com o objetivo de adaptação ao novo cenário competitivo mundial.

Esses organismos iniciaram uma verdadeira mudança em seus discursos nos últimos anos. Se em momentos anteriores, as recomendações privilegiavam os aspectos econômicos e necessários de ajustes estruturais na economia, sob o mote do Consenso de Washington, agora, há um compilado de documentos orientadores que colocam questões sociais como pauta importante. Segundo Vivian Ugá (2011), essa mudança de retórica não aconteceu por acaso, mas devido à necessidade de legitimação, isto é, dar um caráter mais "humano" às reformas liberalizantes. Apesar dessa transformação, e, de atualmente existir um discurso aparentemente mais justo e que coloca em debate os aspectos sociais da realidade mundial, o que se vê, na verdade, é ainda a velha propagação por esses organismos da agenda neoliberal, e a defesa da sobreposição dos interesses do capital às necessidades sociais, ainda que essa prédica não seja completamente explícita.

Na conjuntura atual, as políticas sociais têm incorporado cada vez mais as medidas de ativação, a partir da mediação do Estado schumpeteriano, fato que pode ser considerado um retrocesso na garantia dos direitos de cidadania (PEREIRA-PEREIRA, 2013). Destaca-se aqui, a crescente vinculação entre a ativação e a assistência social, destinada, neste entendimento, aos pobres capazes para o trabalho (ERANSUS, 2005). Segundo Abrahamson (2009), as medidas de ativação se relacionam de forma peculiar com a assistência social, pois é dada maior ênfase na obrigação dos demandantes desta política em se submeter a medidas de controle social, por meio de esquemas de qualificação profissional.

Essa relação é respaldada pelo discurso liberal revisitado, de que as políticas de proteção social causam a dependência dos indivíduos, e, por isso, é fundamental o combate a passividade desses sujeitos, que devem garantir seu próprio bem-estar, por meio do mercado. Para Pascual et al. (2012), a luta contra a dependência é difundida pelo discurso da ênfase na autonomia e na promoção da responsabilidade individual, isto é, o sujeito não está em situação de vulnerabilidade frente a um mercado de trabalho precarizado, mas sim, por não conseguir reunir potencialidades que garantam sua inserção, dessa forma, é considerado como um indivíduo “psicologicamente débil". A partir desse ideário, ressurge assim a figura do pobre merecedor e do pobre não merecedor de proteção social. Para os autores, o paradigma ativador pode ser definido da seguinte forma: 
Um modo de intervenção individualizante, dirigido à promoção do governo de si mesmo, que restringe o âmbito público a uma intervenção terapêutica, dirigida a atacar o risco da dependência (...). Neste regime disciplinador se fomenta o autodisciplinamento, em que o próprio individuo é que tem que se responsabilizar por si mesmo e contribuir ativamente a um processo de autoajuda (PASCUAL, et al., 2012, p. 59, Tradução nossa).

Esta lógica remonta aos tempos em que vigoravam as legislações seminais, que podem ser consideradas como expressão da relação histórica entre proteção social e trabalho. Segundo Behring e Boschetti (2008), o objetivo precípuo dessas leis era manter os trabalhadores sob regime de exploração do capital, em que era exigido dos pobres merecedores de assistência social a contrapartida do trabalho obrigatório. Dentre o conjunto de legislações, destaca-se a Lei dos Pobres, de 1834, que estabeleceu definitivamente o primado liberal do trabalho ${ }^{14}$ como única forma de sobrevivência, e definiu que o atendimento à população pobre seria cada vez mais seletivo e residual (BOSCHETTI, 2003; PEREIRA-PEREIRA, 2008). Dessa forma, um dos impasses da proteção social no capitalismo constitui-se em

[...] lidar com o exército de reserva criado pelo próprio sistema para se reproduzir; ou de como fazer para evitar que os pobres aptos para o trabalho, mas sem trabalho, ao serem protegidos como sujeitos de direitos, fiquem 'mal acostumados' e deixem de se guiar pela ética capitalista (PEREIRAPEREIRA, 2013, p. 643).

$\mathrm{Na}$ contemporaneidade, o paradoxo entre proteção social e trabalho vem se manifestando mais nitidamente. Existe hoje, uma tendência denominada por Pereira-Pereira (2012), como laborização da política social, que consiste em ativar os indivíduos que demandam proteção social ao trabalho, e, é um conceito vinculado ao workfare e a lógica de funcionamento do Estado schumpeteriano. Nesse contexto, destaca-se a política de educação, que tem se reduzido ao treinamento rápido para o mercado de trabalho precário, sendo submetida ao que Wacquant (2003), designa como learnfare, que se baseia na exigência de contrapartida vinculada à educação, com obrigatoriedade de inserção de indivíduos em escolas ou cursos profissionalizantes, em troca de proteção social mínima. Destarte, Jessop (2008) afirma que a política de educação tem incorporado o chamado projeto trabalhista, limitando-se à qualificação profissional para a busca de emprego, e cita também a política de assistência social, que deixa de ser constituída por uma rede de proteção, para ser um meio de acesso ao trabalho (PEREIRA-PEREIRA, 2012).

\footnotetext{
${ }^{14}$ Princípio segundo o qual os indivíduos devem manter a si e as suas famílias, única e exclusivamente, por meio, da venda de sua força de trabalho (BOSCHETTI, 2003).
} 
Dessa forma, no próximo capítulo será aprofundado como a política de assistência social passa a incorporar essa lógica, tornando-se uma política que serve de mediação para acesso de seus usuários ao mercado de trabalho, principalmente por meio das medidas de ativação. 


\section{CAPÍTULO 3}

\section{ASSISTENNCIA SOCIAL E TRABALHO: UMA CONTRADIÇAO HISTÓRICA E ATUAL}

\subsection{Assistência social como política de seguridade social}

O conceito de seguridade social, como já destacado anteriormente, pode ser situado a partir da instituição do Plano Beveridge, apresentado na Inglaterra, durante ano de 1942, sob a égide do Estado fordista-keynesiano. O conteúdo do documento propunha um sistema universal, que garantisse condições dignas de vida a todos os cidadãos, por meio de políticas sociais, opondo-se à lógica do seguro social bismarckiano. O Plano foi divulgado no Brasil em 1943, e foi considerado como um modelo de seguridade a ser seguido (BOSCHETTI, 2006). Entretanto, dada a particularidade histórica, econômica e política brasileira, que conformou o desenvolvimento do Estado social no país, somente décadas depois é que se tornou possível a implementação de um modelo de seguridade social semelhante ao beveridgiano no Brasil.

Enquanto os países desenvolvidos experimentavam o pleno emprego keynesiano, o fordismo como sistema de produção e de mediação das relações sociais, assim como a ampliação das políticas de bem-estar, no Brasil iniciavam-se as primeiras ações de caráter social, ainda não organizadas formalmente sob a forma de um sistema de proteção social. De acordo com Boschetti (2006), as primeiras ações brasileiras consideradas de proteção social estão predominantemente relacionadas com questões relativas ao trabalho e situam-se a partir da expansão da intervenção do Estado durante a década de 30, do século XX.

Como exemplo, é possível citar en passant, a criação da Lei Eloy Chaves, que no ano de 1923, instituiu a Caixa de Aposentadoria e Pensões (CAP) para os trabalhadores das empresas ferroviárias, e pode ser considerada o marco inicial da previdência brasileira (BOSCHETTI, 2006). Outras regulações sobre o trabalho se multiplicaram nas décadas subsequentes, sobretudo na Era Vargas, como a criação dos Institutos de Aposentadorias e Pensões (IAPs), a criação do Ministério do Trabalho, Indústria e Comércio, que somados ao acúmulo de ações ao longo das décadas posteriores, culminou na promulgação da Lei Orgânica de Previdência Social (LOPS), durante os anos 60.

Com relação às outras áreas, destaca-se também a elaboração do Código de Menores, em 1927, que tinha em seu conteúdo aspecto conservador e punitivo; e a criação da Legião Brasileira de Assistência (LBA), no ano de 1942, que possuía como escopo inicial a prestação 
de assistência aos familiares dos soldados da Segunda Guerra Mundial, e que anos mais tarde, teve a expansão de suas atividades em todo o país, sempre ancorada na lógica da benemerência e da assistência como ajuda e não como direito. Para Behring (2010), no contexto do Estado social capitalista, o trabalho torna-se o ingrediente que determina a contradição entre previdência e assistência social, que no contexto brasileiro, passam a distinguir-se uma da outra com definições mais claras tardiamente (BOSCHETTI, 2006).

A estruturas dos sistemas de proteção social em âmbito mundial começam a ser questionadas com a crise do capital, durante a década de 1970, em que ocorrem mudanças significativas na esfera do trabalho, com o processo de reestruturação produtiva e a expansão da acumulação flexível, além das transformações no padrão de intervenção do Estado, que passa a reger-se pelo ideário neoliberal. Neste período, vigorava no Brasil a Ditadura Militar, que Mota (2011, p.137) resume da seguinte forma ao discutir as funções do Estado ditatorial a partir de sua intervenção no campo das políticas sociais:

Parametrado pelas exigências do processo de acumulação, pela contenção das formas de rebeldia política das classes subalternas e pela necessidade de estabelecer uma ordem consentida, além de atender exigências do grande capital, o Estado militar-tecnocrático promove algumas mudanças no âmbito das políticas sociais, procurando funcionalizar essas demandas de acordo com o seu projeto político, por meio da expansão seletiva de alguns serviços sociais. Essa ampliação da cobertura de programas sociais, em que se incluem as políticas de seguridade social, respondem, preponderantemente, pela estratégia de modernização autoritária adotada pelos governos militares (MOTA, 2011, p. 137).

Segundo Boschetti (2006), após o fim do governo ditatorial, o conjunto das políticas sociais ainda não estava organizado sob a forma de um sistema de seguridade social, contudo, as discussões políticas e teóricas sobre o tema foram retomadas nesse período, com o objetivo de garantir a reorganização dessas políticas e uma fundamentação com preceitos mais justos. Nesse sentido, a elaboração da Constituição Federal foi permeada por uma intensa correlação de forças, na qual contrastavam-se propostas inovadoras e democráticas, com objeções conservadoras e retrógadas, dos grupos de direita representantes da burguesia. No que concerne ao âmbito da proteção social, o principal avanço da Constituição de 1988 refere-se ao conceito de seguridade social (MOTA, 2011), definido como um conjunto integrado de ações de iniciativa do poder público e da sociedade, destinadas a assegurar os direitos relativos à saúde, à previdência e à assistência social. 
A organização e conceituação da seguridade social presentes na Constituição representaram um avanço significativo no âmbito do Estado social brasileiro. Entretanto, conforme aponta Behring (2010), a seguridade brasileira, de aspecto beveridgiano e universalista, formaliza-se tardiamente se comparado com a trajetória dos países desenvolvidos. Além disso, os obstáculos para materialização dos direitos presentes na Carta Magna foram e ainda são enormes, tendo em vista o contexto de contrarreforma neoliberal do Estado (BEHRING, 2008) presente no país durante a década de 90. Nessa esteira, Mota (2011, p. 146) afirma:

A despeito da Constituição de 1988 conter princípios que garantem a universalização da seguridade social, observamos que a emergência de novos processos políticos, ao lado do agravamento da crise econômica, gera um movimento, por parte do grande capital e da burocracia estatal, que procura negar aquelas conquistas obtidas, sob a alegação da necessidade de adequação do modelo de seguridade social às atuais reformas econômicas do país.

Na conjuntura atual, a seguridade social é ainda fortemente permeada por este movimento de obstaculização dos direitos, que prioriza os interesses do capital, em detrimento do fortalecimento e investimento em ações relativas à previdência social, assistência social e saúde. Como exemplo dessa lógica, é possível mencionar o mecanismo amplamente utilizado pelo governo federal, denominado como Desvinculação das Receitas da União ${ }^{15}$ (DRU), que permite que o governo aplique livremente recursos do fundo público, que poderiam ser destinados às políticas de seguridade, e, que em geral, são utilizados utilizado para pagamento de juros da dívida pública e ao aumento do superávit primário (SALVADOR, 2010).

Em meio à crise política brasileira, os prognósticos para a seguridade social não poderiam ser piores. Com o governo ilegítimo de Michel Temer, que assumiu a presidência através de conchavos políticos imorais, tendo como único compromisso a defesa dos interesses da classe burguesa, as políticas de seguridade social vêm sofrendo ameaças constantes de desmonte, seja por meio do financiamento ou pelo viés conservador do governo, que se opõe fundamentalmente à concepção dessas políticas. Nesse contexto, é importante lembrar a concepção de seguridade social presente na Carta de Maceió, elaborada pelo Conselho Federal

\footnotetext{
${ }^{15}$ Até recentemente o Governo Federal tinha autorização para utilizar 20\% dos recursos através da DRU. A partir de 24 de agosto de 2016, o Senado Federal votou a Proposta de Emenda à Constituição (PEC) 31/2016, que altera o Ato das Disposições Constitucionais Transitórias e, prorroga até 2023, o livre uso de parte da arrecadação (todos os impostos e contribuições sociais federais), ampliando, porém, o seu percentual de $20 \%$ para $30 \%$. Disponível em: http://www12.senado.leg.br/noticias/materias/2016/08/24/senado-aprova-proposta-que-prorroga-a-dru-ate2023. Acesso em 23/09/2016.
} 
de Serviço Social (CFESS) em conjunto com os Conselhos Regionais de Serviço Social (CRESS), no ano de 2000:

\begin{abstract}
A seguridade social é, sobretudo, um campo de luta e de formação de consciências críticas em relação à desigualdade social no Brasil, de organização dos trabalhadores. Um terreno de embate que requer competência teórica, política e técnica. Que exige uma rigorosa análise crítica da correlação de forças entre classes e segmentos de classe, que interferem nas decisões em cada conjuntura. Que força a construção de proposições que se contraponham às reações das elites político-econômicas do país, difusoras de uma responsabilização dos pobres pela sua condição, ideologia que expressa uma verdadeira indisposição de abrir mão de suas taxas de lucro, de juros, de sua renda da terra (CFESS/CRESS, 2000).
\end{abstract}

O documento ressalta a importância do posicionamento político, teórico e técnico ancorados em uma perspectiva crítica, para defesa da seguridade social, em meio à intensa correlação de forças existentes, haja vista a disputa de interesses entre as classes sociais no Brasil. Dessa forma, torna-se premente a organização e a luta dos trabalhadores e movimentos sociais frente às sérias ameaças vivenciadas pela seguridade social e pelos demais direitos existentes na conjuntura atual.

\title{
3.2. Assistência social na atualidade: do percurso histórico do favor ao direito ao possível retorno ao passado?
}

A assistência social não é um fenômeno que surgiu recentemente, é, na verdade, um acontecimento antigo (PEREIRA-PEREIRA, 1996), que necessita ser analisada a partir de suas determinações históricas, para então ser compreendida na atualidade. As primeiras práticas que podem ser atribuídas a uma forma primária da assistência social, remontam às relações e regulações constituídas no âmbito do grupo familiar, da vizinhança e do trabalho, denominados por Castel (1998), como as redes de sociabilidade primária. Eram essas redes responsáveis pelas práticas assistenciais, que não tinham caráter organizado e formal, e prescindiam de instituições mediadoras específicas, como o Estado. Dessa forma, tais práticas não eram reguladas por nenhum tipo de padrão normativo instituído, eram construídas a partir dos costumes e com base no apego às relações permanentes de dependência e interdependência entre os membros de determinada comunidade (CASTEL, 1998).

A partir do desatrelamento desse tipo de organização social, devido ao surgimento de questões mais complexas no seio da sociedade, até então de caráter feudal, passam a existir estruturas especializadas de atendimento assistencial, geralmente associadas à filantropia cristã 
e à caridade privada. Em geral, as regulações das sociedades pré-capitalistas sobre questões sociais, tinham como objetivo precípuo o controle, a manutenção da ordem e a punição da vagabundagem, e podem ser consideradas como protoformas de políticas sociais (BEHRING E BOSCHETTI, 2008). Nesse sentido, Pereira-Pereira (2008) entende que a intervenção do Estado surge a partir do momento em que se constata que a caridade cristã não era suficiente para conter as desordens advindas da substituição do feudalismo pela ordem capitalista nascente.

Como exemplo da iniciativa do Estado na regulação da pobreza, por meio de práticas assistenciais, é possível citar o conjunto das Leis dos Pobres (Poor Law) na Inglaterra, que de forma geral, são consideradas ações pontuais e restritas, que não possuíam como escopo a concepção da assistência enquanto direito, mas sim como mecanismo de controle e punição da população pobre. As ações restritas do Estado liberal na regulação da vida social, juntamente com o aumento do pauperismo, fruto da riqueza acumulada e da exploração do trabalho pelo capital, resultaram numa crescente agitação social e no fortalecimento e organização da classe trabalhadora, que reivindicava melhores condições de vida e trabalho. Diante das constantes pressões, o liberalismo passou a incorporar ações de cunho mais "social" (PEREIRAPEREIRA, 2008), o que abriu caminho para o advento do Estado social e a mudança no padrão de regulação estatal. Dessa forma, nos países do capitalismo central, salvo suas especificidades, a assistência social foi consolidada como direito social.

No Brasil, a primeira iniciativa palpável no campo da assistência social ocorre no ano de 1942, com a criação da Legião Brasileira de Assistência (LBA), que tinha suas ações fundadas na lógica da filantropia e da benemerência, cujas principais características podem ser definidas como a fragmentação e a pontualidade no atendimento, além da participação de primeiras damas ${ }^{16}$ na organização e gestão das ações nos municípios. Com o passar dos anos, as ações da LBA expandiram-se e foram diversificadas, até que em 1974, foi incorporada ao Ministério da Previdência e Assistência Social (MPAS), tornando-se de fato uma entidade pública de assistência social (BOSCHETTI, 2006).

Historicamente, as ações de assistência social no contexto brasileiro foram marcadas pela fragmentação e descontinuidade. É de maneira tardia que a assistência é situada como política pública, e, por sua vez, como um direito social reclamável. A partir da promulgação da

\footnotetext{
${ }^{16} \mathrm{O}$ primeiro damismo foi a denominação cunhada para definir a participação de primeiras damas de governantes brasileiros nos assuntos relacionados à assistência social, a partir de um viés conservador, que situa a assistência como uma prática improvisada e pontual, cuja principal vertente é a lógica do favor e da benesse, descolada, portanto, do marco de direito de cidadania.
} 
Constituição Federal de 1988, a assistência social torna-se uma política constitutiva da seguridade social, contudo, para Boschetti (2003), quando ganha o status de dever político e legal determinado, apresenta-se então a dificuldade conceitual de defini-la (BOSCHETTI, 2003). Essa imprecisão conceitual ocorre, em grande parte, devido à interpretação que se faz da assistência social e ao relacioná-la constantemente pelo que aparenta ser, e pelo mau uso político que se fez dela (PEREIRA-PEREIRA, 1996).

Apesar do estabelecimento formal da assistência social como direito social, observouse um descompasso em sua efetivação e regulamentação, sobretudo devido às tendências conservadoras do projeto neoliberal, vigente no país naquele período. A Lei Orgânica da Assistência Social (LOAS), que regulamentou as ações da assistência social, somente foi aprovada no ano de 1993, no governo de Itamar Franco. De acordo com Couto (2010), a aprovação da LOAS foi resultado da organização e reivindicação de parte da sociedade civil, de instituições de classe e do Ministério Público. E apesar de trazer avanços importantes, a LOAS teve seu projeto original modificado e incorporou demandas conservadoras, como por exemplo, a concepção de mínimos sociais, e o critério de renda inferior a 1/1/4 de salário mínimo para acesso ao Benefício de Prestação Continuada (BPC) (MOTA; MARANHÃO; SITCOVSKY, 2010).

Dessa forma, o que se verificou após a promulgação da LOAS, foi uma tendência de continuidade às ações fragmentadas e descontínuas, cuja maior expressão foi o Programa Comunidade Solidária (PCS), criado no governo de Fernando Henrique Cardoso. O PCS tinha como característica a ausência de continuidade e sistematicidade nas ações e projetos de assistência social (MOTA; MARANHÃO; SITCOVSKY 2010), retomando o caráter de solidariedade e voluntarismo (COUTO, 2010), além de apresentar um forte vínculo com o setor privado, por meio de parcerias, que deixava clara a desresponsabilização do Estado no enfrentamento das expressões da questão social. Neste período, também foi criada a primeira Política Nacional de Assistência Social, aprovada em 1998, mas que não foi implementada e nem sequer é lembrada, tendo em vista sua pulverização e o caráter focalista (COUTO et al., 2012).

Com o governo de Luís Inácio Lula da Silva, as esperanças de que a orientação dada à política econômica e fiscal seriam baseadas numa perspectiva democrática e mais justa, foram totalmente frustradas. Segundo Pereira-Pereira (2012), o governo Lula adotou uma postura ambígua diante do legado de seu antecessor, e por isso deu continuidade às políticas de cunho 
neoliberal, inclusive intensificando o ajuste macroeconômico, mas também incorporou algumas demandas sociais, ainda que de maneira restrita e submetida à lógica do capital.

Foi neste contexto que foi criada a Política Nacional de Assistência Social (PNAS) em 2004, que definiu o Sistema Único de Assistência Social (SUAS), além da primeira Norma Operacional Básica do SUAS (NOB-SUAS), publicada em 2005 e revista em 2012, e a Norma Operacional Básica de Recursos Humanos (NOB/RH-SUAS), no ano de 2006. É inegável que a PNAS foi uma significativa normativa, que esclareceu as diretrizes para efetivação da assistência social, baseada num modelo de gestão compartilhado, e que possibilitou a implementação do SUAS, que orienta as ações de assistência social, de maneira organizada, hierarquizada e em articulação com as iniciativas da sociedade civil. Nesse sentido, Boschetti, Teixeira e Salvador (2013, p. 2) afirmam:

Do ponto de vista da concepção de assistência social, é inegável que a institucionalidade do SUAS tenta retirar a assistência social do arcabouço da filantropia e cria diretrizes, critérios e forte arcabouço legal, antes inexistente e de difícil estruturação em uma nação federada, com fortes disparidades nacionais e locais. A definição conceitual de assistência como política de proteção social presente na PNAS e no SUAS amplia suas feições e funções ali determinadas, rompendo com a histórica nomenclatura até então existente. Contudo, esta concepção e a formulação dos serviços hierarquizados em proteção básica e de média complexidade não conseguiram, até o momento, romper com a prática enraizada na história da assistência social, que privilegia e enfatiza abordagens individuais, familiares ou grupais.

Uma outra característica presente na política de assistência social e que é determinante em sua constituição, apesar de pouco discutida, é a relação entre Estado e sociedade civil. A PNAS e a NOB definem que o SUAS seja constituído de redes formadas pela parceria estre o Estado e organizações sem fins lucrativos, para que assim sejam ofertados de forma integrada e organizada os serviços socioassistenciais. Apesar dessa diretriz parecer inofensiva, já que os serviços ofertados pelas entidades privadas são denominados como serviços públicos de caráter não estatal, é importante analisar mais profundamente tal questão. Sitcovsky (2010) demonstra que essa orientação dada à política de assistência social foi herdada do governo Fernando Henrique Cardoso, que sob forte influência do receituário neoliberal, fortaleceu as relações do Estado com o terceiro setor, através da ideologia da solidariedade, do altruísmo, o que caracterizou um dos eixos da contrarreforma ${ }^{17}$ do Estado. Nesse sentido, ressurge a ideia do

\footnotetext{
${ }^{17} \mathrm{O}$ termo contrarreforma é utilizado no sentido crítico para expor as reais intenções da auto-designada reforma do Estado brasileiro, de cunho conservador, e que baseava-se em ações de orientação neoliberal, voltadas para o
} 
Estado gerencial, ou seja, o Estado é o coordenador do processo de articulação entre as entidades privadas de assistência social (SITCOVSKY, 2010).

Diante deste contexto, ao realizar uma análise criteriosa da assistência social como política constitutiva da seguridade social, é possível perceber a tendência contemporânea de privatização e mercantilização das políticas de saúde e previdência, e como contraponto, a supervalorização da assistência social, no sentido em que passa a ser percebida como principal mecanismo de enfrentamento da desigualdade social e de proteção social, principalmente por meio dos Programas de Transferência Condicionada de Renda, como o Programa Bolsa Família (MOTA, 2010). Dessa forma, percebe-se que o ideário construído para sustentar tal centralidade é falseado, tendo em vista que a proteção social é atribuída ao conjunto das políticas sociais, não sendo responsabilidade exclusiva da assistência social, além do que, o enfrentamento real da desigualdade social é também de ordem econômica e não somente social.

Além disso, chama a atenção a crescente incorporação da estratégia de focalização na assistência social. A ideia subjacente a tal questão é de que a política de assistência social teria um caráter residual e compensatório, isto é, voltado a determinado segmento da população que não consegue se sustentar (COUTO, 2015). Nessa esteira, a autora destaca ainda a perspectiva que vem se expandindo, das capacidades individuais, que limitariam ao sujeito demandante a responsabilidade por sua situação e o engajamento para melhora-la, reforçando a lógica da psicologização das relações sociais, que omite a luta de classes no contexto da luta pelos direitos sociais (COUTO, 2015).

Na conjuntura atual, também é premente a ameaça de desmonte e retrocesso da política de assistência social. Uma das primeiras ações do presidente ilegítimo Michel Temer foi a extinção do Ministério do Desenvolvimento Social e Combate à Fome (MDS), realocando a pasta da assistência social ao Ministério do Desenvolvimento Social e Agrário (MDSA), o que mais uma vez, situa a assistência social como política secundária, excluindo a necessidade de um corpo próprio de funcionamento com técnicos qualificados. Outra decisão, que define claramente o caminho que o atual governo irá seguir, é o anúncio que a esposa de Temer assumirá um cargo na área social, com o objetivo de coordenar o então denominado Programa

mercado, para a privatização em massa, assim como para a perda de direitos e desmonte das políticas sociais (BEHRING, 2008). 
Criança Feliz ${ }^{18}$, lançado para atender crianças do Bolsa Família, o que resgata a lógica do primeiro damismo e da assistência social como favor.

\subsection{Contradição histórica entre assistência social e trabalho e suas expressões na contemporaneidade}

A contradição entre assistência social e trabalho é histórica e se faz presente desde as origens do capitalismo. Ao analisar as primeiras intervenções de caráter social, Castel (1998) afirma que a população demandante era diferenciada por um critério básico: ser ou não capaz de trabalhar. Segundo o autor, os sujeitos incapacitados para o trabalho, desde que reconhecida sua incapacidade, eram o alvo ideal das ações assistenciais. Ao contrário daqueles capazes de trabalhar, mas que não o faziam por qualquer motivo, considerados como vagabundos e não merecedores de qualquer tipo de assistência.

Nesse sentido, a Lei dos Pobres (Poor Laws), que vigorou na Inglaterra durante vários séculos, pode ser considerada um exemplo da incorporação da lógica dos pobres merecedores de assistência, considerados inaptos para o trabalho, e dos pobres não merecedores, ou seja, capacitados para o trabalho. A radicalização dessa tendência ocorre sob a égide do Estado liberal, com a aprovação da Nova Lei dos Pobres (New Poor Law), no ano de 1834, que acentua o caráter punitivo e de obrigação ao trabalho daqueles considerados aptos, por meio das denominadas workhouses. De acordo com Boschetti (2016), a dualidade existente entre capazes e incapazes para o trabalho no campo da assistência, representa na verdade, um mecanismo de reprodução da superpopulação relativa estagnada.

Durante o século XX, com o predomínio do Estado social e o reconhecimento da assistência social enquanto direito, há uma relação menos tensa com o trabalho, porém, sempre contraditória (BOSCHETTI, 2016). Este aspecto contraditório pode ser atribuído ao fato de que a assistência social possui caráter restritivo, pois é prestada aqueles que necessitam, e, uma vez que, o trabalho não é garantido a todos, existe uma relação excludente, que pode causar um conjunto de injustiças sociais (BOSCHETTI, 2003). Na contemporaneidade, no contexto de crise do capital e devido a impossibilidade de garantir o direito ao trabalho, a assistência social passa a incorporar os considerados aptos para o trabalho. De acordo com Mota, Maranhão e Sitcovsky (2010, p. 196):

\footnotetext{
${ }^{18}$ O Programa Criança Feliz prevê, dentre outras ações, visitas domiciliares semanais de acompanhamento dos filhos dos beneficiários do Bolsa Família, o que pode ser considerado mais um mecanismo de controle e invasão da privacidade dos usuários, do que de fato, um programa que garanta acesso a direitos.
} 
A assistência social no século XXI está adquirindo a condição de mecanismo integrador, em lugar do papel desempenhado pelo trabalho assalariado. Aqui, o maior destaque fica por conta dos programas de transferência de renda (...). No nosso entender esta é a maior tensão presente na política de assistência social, haja vista a impossibilidade estrutural dela assumir esse papel.

A tendência apontada pelos autores, de substituição do papel integrador do trabalho pela política de assistência social, pode ser considerada perniciosa. Nessa perspectiva, o direito ao trabalho com proteção, ainda que limitada, dados os níveis elevados de informalidade e precariedade no mercado brasileiro, passa a ser deslocado à uma proteção limitada, ofertada pela política de assistência social, por meio de benefícios de transferência de renda com baixos valores, o que não possibilita a organização da classe trabalhadora, em comparação com o trabalho, além de não promover de fato essa integração, haja vista a existência de uma impossibilidade estrutural (MOTA; MARANHÃO; SITCOVSKY, 2010).

Ao analisar os programas de transferência de renda, em especial o Programa Bolsa Família, Sitcovsky (2010) afirma que estes estariam alterando a relação de atração e rejeição entre assistência social e trabalho. Contudo, o rompimento desta dicotomia é apenas aparente. Os programas de transferência de renda, na realidade, reeditam a contradição existente entre assistência e trabalho (BOSCHETTI, 2016), uma vez que, é garantido o repasse de valores mínimos, que não constitui uma substituição de fato ao trabalho, além dos critérios vexatórios e as condicionalidades, que em determinados casos exigem algum tipo de contrapartida relacionada ao mundo do trabalho, como a qualificação profissional, por exemplo.

Neste contexto, a assistência social tem incorporado cada vez mais a função de integração ao trabalho e de ativação de seus demandantes. Segundo Couto (2015), baseado na lógica do workfare, caso o indivíduo não consiga acessar qualquer tipo de trabalho, caberá a assistência social a função de "capacitá-lo", para que assim possa ser merecedor do benefício recebido. Nesse sentido, Boschetti (2016, p. 167) afirma:

A inevitável evidência de impossibilidade de estabelecimento de pleno emprego no capitalismo coloca a assistência social como âncora na extremidade da fronteira entre trabalho e não trabalho e se associa a tendência geral das políticas sociais de 'ativar' os trabalhadores (e às vezes mesmo as pessoas com certas incapacidades/deficiências) a perseguir o caminho da busca de um trabalho cujo horizonte parece cada vez mais inacessível.

Portanto, as políticas de ativação são as formas atuais de expressão da contradição entre assistência social e trabalho (BOSCHETTI, 2016). Em meio a essa tendência, Paiva (2014) 
discute a contradição denominada enigmática entre assistência e trabalho e traz significativos relatos de profissionais do SUAS, que muitas vezes reproduzem um discurso conservador e de reforço à lógica do primado do trabalho. Além disso, a autora afirma que a universalização da seguridade social apresenta somente um caminho possível, a expansão da política de assistência social, com objetivo de atender as necessidades dos trabalhadores superexplorados (PAIVA, 2014). Entretanto, essa ideia reforça o que Mota (2010) denomina como fetichização da assistência social, o que atribui somente a essa política, a responsabilidade pela proteção social, superdimensionando-a.

As normativas da política de assistência social expressam em parte de seu conteúdo as tendências apontadas anteriormente (BOSCHETTI, 2003). Segundo a Constituição Federal de 1988, um dos objetivos da assistência social, é “(..) a promoção da integração ao mercado de trabalho", que posteriormente é ratificado na Lei Orgânica da Assistência Social (LOAS), sem, no entanto, existir uma problematização desse objetivo ou delimitá-lo dentro da política. Os documentos posteriores, como a Política Nacional de Assistência Social (PNAS) e a Norma Operacional Básica do Sistema Único de Assistência Social (NOB/SUAS), e outros documentos relacionados também não problematizaram explicitamente tal questão.

Devido ao vazio existente acerca de definições e competências com relação a esse objetivo, se multiplicaram ações fragmentadas, pontuais e isoladas, realizadas pelos municípios brasileiros, cuja finalidade é a geração de trabalho e renda para os usuários da assistência social (SOUZA, 2013). Recentemente, na tentativa de dar um direcionamento para essa questão e tendo em vista a grande quantidade de ações diferenciadas que eram realizadas pelas Secretarias de assistência social em todo o Brasil, o Conselho Nacional de Assistência Social (CNAS) definiu, por meio da Resolução $n^{\circ} 33 / 2011$, a promoção da integração ao mercado de trabalho no campo da assistência social e estabeleceu os requisitos necessários para essa ação. De acordo com a Resolução, a promoção da integração ao mercado de trabalho se dá através:

De um conjunto integrado de ações das diversas políticas cabendo à assistência social ofertar ações de proteção social que viabilizem a promoção do protagonismo, a participação cidadã, a mediação do acesso ao mundo do trabalho e a mobilização social para a construção de estratégias coletivas (BRASIL, 2011, p. 2).

Ancorado na respectiva Resolução do CNAS, foi instituído pelo Ministério do Desenvolvimento Social e Combate à Fome (MDS), no ano de 2012, o Programa Nacional de Promoção do Acesso ao Mundo do Trabalho (ACESSUAS/TRABALHO), que tem como principal mote a promoção dos usuários da assistência social ao mundo do trabalho, por meio 
de ações articuladas, que garantam a autonomia dos indivíduos. É possível notar que nos últimos cinco anos tem crescido as definições e programas que colocam em destaque a função da assistência social enquanto política que deve promover de forma direta ou indireta o acesso da população usuária ao mercado de trabalho. Essa problemática coloca a assistência social num limbo entre a garantia dos direitos de cidadania e a sua destituição, a partir do momento em que passa a ser considerada como uma "porta de saída" da população demandante, o que também enfraquece o caráter dermercadorizável que a política deve ter.

Em geral, o discurso do acesso ao mundo do trabalho por meio da assistência social vem ancorado na ideia de geração de protagonismo, autonomia, promoção social, potencialidades e outras denominações em voga atualmente. Entretanto, ao aprofundar a análise sobre tal questão, percebe-se que esse discurso pode estar embasado na ideia de promoção de capacidades, que tem como fim a liberdade do indivíduo, que deve reunir os recursos disponíveis para garantir seu bem-estar, com base naquilo que entende como melhor para si mesmo.

Essa lógica é fundamentada na teoria das capacidades, do economista indiano Amartya Sen, que vem ganhando destaque nos últimos anos, sobretudo no âmbito da política de assistência social. Segundo Sen (2010), a pobreza deve ser analisada como privação de capacidades básicas, o que o autor denomina como "pobreza de capacidade". O foco da teoria seniana é o indivíduo, por isso, é ele que deve ser empoderado, para que consiga sair da situação em que se encontra. Para Mauriel (2010), o pensamento de Sen mascara as condições estruturais de pobreza e resgata o princípio da liberdade individual, de natureza liberal, o que promove um verdadeiro retrocesso para as políticas sociais de cunho universal. Além disso, esse construto teórico fundamenta as ações de ativação para o trabalho, que passam a ser consideradas como um mecanismo de promoção das capacidades.

O programa ACESSUAS/TRABALHO possui em seu conteúdo normativo estreita relação com o Plano Brasil Sem Miséria ${ }^{19}$, que tem a inclusão produtiva como um dos eixos de ação. O termo inclusão produtiva não possui definição conceitual, mas pode expressar a contradição entre capital e trabalho (SOUZA, 2013), e, possui atualmente como objetivo, a promoção do acesso da população em extrema pobreza ${ }^{20}$ ao mercado de trabalho. Um dos

\footnotetext{
${ }^{19}$ O Plano Brasil Sem Miséria foi criado no governo de Dilma Rousseff, em junho de 2011, e tem como objetivo a elevação da renda e das condições de bem-estar da população que vive em situação de extrema pobreza. O Plano define que essas famílias deverão ser incluídas em programas e serviços de diferentes áreas.

${ }^{20}$ A definição de extrema pobreza neste caso está relacionada com o critério estabelecido pelo Governo Federal para acesso a diferentes programas e ações, que determina que para uma família ou indivíduo ser extremamente pobre deve ter uma renda per capita mensal de até $\mathrm{R} \$ 85$. De acordo com Pereira e Amorim (2010), essa definição circunscreve a pobreza a uma análise limitada, que a desconsidera como fenômeno caráter multidimensional, isto porque é abordada somente um aspecto da questão, isto é, a renda.
} 
principais programas do Plano, que possui intrínseca relação com a assistência social, é o Programa Nacional de Acesso ao Ensino Técnico e Emprego (PRONATEC/BSM), que tem como público prioritário os beneficiários dos programas federais de transferência de renda, ou seja, beneficiários do Programa Bolsa Família (PBF) e do Benefício de Prestação Continuada (BPC), e pessoas inscritas ou em processo de inscrição no Cadastro Único para Programas Sociais do Governo Federal (CadÚnico).

Em geral, os programas de qualificação profissional possuem uma forte relação com a pobreza, tanto em seu conteúdo, como no público a que se destina. Essa relação não é novidade e também tem acompanhado as políticas de ativação em outros países, ressalvadas as especificidades de cada realidade. De acordo com Eransus (2005), tal tendência está relacionada com a configuração da proteção social na atualidade, que garante prestações assistenciais de baixo valor, destinada a uma pequena parcela da população, que passa a ser classificada novamente a partir da lógica entre pobres capazes para o trabalho e não capazes. Para aqueles considerados capazes é estabelecido um conjunto de políticas de ativação, que em alguns países são definidas como obrigatórias.

Nesse sentido, o merecedor de proteção social passa a ser aquele considerado miserável, que consegue comprovar seu mérito individual e disposição no cumprimento de contrapartidas (PEREIRA, 2016). O fundamento ideológico desse pensamento é ancorado na meritocracia, que tem sua expansão no contexto neoliberal. Segundo Livia Barbosa (2003), apesar do conceito de meritocracia não ser claro, é possível defini-lo como o construto de valores que irão designar que a posição ocupada por cada sujeito na sociedade depende do mérito individual. Ao ser incorporada pelo conjunto das políticas sociais, a meritocracia subverte os direitos sociais em favor, destituindo o caráter civilizatório destes (PEREIRA, 2016). Dessa forma, esse discurso

[...] pôs em xeque os valores associados não só ao Estado de bem-estar, mas também ao tipo de homem que, na sua concepção ele criou: reativo, acomodado, esperando da ação do Estado e da sociedade a solução de seus problemas, despreocupado de onde tem o seu salário. Esse tipo social representa a antítese do personagem que deve encarnar os princípios da meritocracia: autônomo, competitivo, empreendedor, criativo, esforçado, tendo o trabalho como valor central de sua existência (BARBOSA, L., 2003, p. 26)

O indivíduo que não pauta suas ações pelos valores defendidos pela meritocracia, passa então a ser estigmatizado, isto é, sua identidade enquanto sujeito é reduzida a atributos considerados indesejados, e, portanto, entendido como estragado ou diminuído, desacreditado 
ou desacreditável ${ }^{21}$ (GOFFMAN, 2008). Nesse sentido, o estigma pode ser compreendido como intrínseco à lógica do mérito por destituição, isso porque, o indivíduo deve comprovar ser suficientemente pobre e ter características que o tornem merecedor ideal de proteção social, reduzindo assim sua humanidade a atributos considerados desejáveis.

Nesta lógica, também há a combinação persistente entre pobreza e trabalho, o que demonstra que o trabalho é compreendido como principal mecanismo de integração, ignorando o que Antunes (2011) vai denominar como processo destrutivo no âmbito da produção, que tem gerado na sociedade uma massa de trabalhadores excluídos e precarizados. Essa leitura reducionista também desconhece que a pobreza é algo necessário para o modo de produção capitalista, portanto, de acordo com Siqueira (2013, p. 164): “(...) o próprio desenvolvimento capitalista, o aumento da riqueza socialmente produzida, não só não reduz a pobreza, como pelo contrário a produz e amplia: com mais desenvolvimento capitalista, maior a pauperização". Na mesma direção, Montaño (2012), afirma que não é a escassez que gera a pobreza no capitalismo, mas é a abundância, isto é, a riqueza concentrada na mão de poucos que gera desigualdade e pauperismo relativo e absoluto.

Como já foi mencionado, os programas de transferência de renda são o mecanismo mais usual que o Estado tem utilizado para assumir parcialmente os pobres aptos para o trabalho. Nos últimos anos, é possível afirmar que houve uma expansão do orçamento da assistência social. Entretanto, esse crescimento e a centralidade que a assistência passa a ter no âmbito da proteção social, se dá por meio da primazia dos programas de transferência de renda, em detrimento da expansão dos serviços socioassistenciais. Segundo Silva (2013), nos últimos anos, houve no Brasil um aumento do recurso do orçamento da assistência social, que cresceu em 255,4\%, entretanto, a maior parte é destinada aos programas de transferência de renda. Boschetti, Teixeira e Salvador (2013) também corroboram essa tendência ao afirmar que todo o orçamento destinado aos serviços do SUAS é menor que o orçamento federal do Bolsa Família.

Diante dessa análise, percebe-se que as medidas de ativação para o trabalho no contexto brasileiro se manifestam de maneira diferenciada, tendo em vista o processo de formação econômico e político do país, que imprimiu características específicas na exploração da força de trabalho ao longo dos séculos. Contudo, conforme demonstrado é possível afirmar que nos últimos anos têm ganhado destaque as ações de acesso ao mundo do trabalho, por meio da

\footnotetext{
${ }^{21}$ Segundo Goffman (2008), o sujeito desacreditado é definido como aquele que sua característica distintiva já é conhecida ou imediatamente evidente. Por sua vez, aquele desacreditável não apresenta sua característica distintiva aparente e nem imediatamente perceptível.
} 
política de assistência social, o que denota o resgate do paradoxo histórico entre trabalho e proteção social, além de colocar em debate o processo de laborização da política social, utilizado por Pereira-Pereira (2012), que se relaciona com a tendência da expansão do workfare. Esse contexto denota a importância da discussão sobre o papel da assistência social na atualidade, enquanto política de seguridade social, que deve ter como princípio norteador a garantia de direitos e não a lógica da rentabilidade econômica (PEREIRA-PEREIRA, 2002). 


\section{CAPÍTULO 4}

\section{POLÍTICAS DE TRABALHO NO BRASIL E O ESTUDO DE CASO DO PRONATEC - BSM}

\subsection{Política de trabalho no Brasil: breve histórico das ações de qualificação profissional}

A política de trabalho brasileira acompanha as conformações do Estado social no país e do desenvolvimento econômico e político, caracterizado pela dependência e subordinação ao capital estrangeiro. De acordo com Pochmann (2012), as primeiras ações do poder público no Brasil, relacionadas à política de emprego, datam da década de 1930, e possuíam como objetivo principal a ampliação dos postos de emprego assalariado. No que tange às primeiras iniciativas de qualificação profissional, é possível citar a criação do Sistema $\mathrm{S}^{22}$, no ano de 1940, por meio do Serviço Nacional de Aprendizagem Industrial (SENAI) e o Serviço Nacional de Aprendizagem Comercial (SENAC), além da inauguração de Escolas Técnicas Federais (OLIVEIRA, 2012).

Nesse sentido, existiu no país durante várias décadas, a predominância de políticas ativas de emprego, em detrimento daquelas consideradas passivas (POCHMANN, 2012; OLIVEIRA, 2012). Essa afirmação é corroborada pelo fato de que somente nas décadas de 1960 e 1970, é que foram implementadas as primeiras medidas relacionadas ao desemprego, que, entretanto, mostraram-se insipientes e pouco efetivas, e, apenas no ano de 1986 é que foi instituído o seguro-desemprego, tendo em vista a conjuntura de expansão do desemprego, em decorrência da crise econômica (POCHMANN, 2012). Tem-se então a constituição de um Sistema Público de Emprego, contudo, ainda insuficiente e fragmentado (SILVA e YAZBEK, 2012).

Durante a década de 1990, acompanhando as recomendações dos organismos multilaterais baseadas no corolário neoliberal, no governo de Fernando Henrique Cardoso, foram realizadas contrarreformas no âmbito do Estado brasileiro, assim como foi promovida uma desregulamentação e flexibilização da legislação trabalhista (OLIVEIRA, 2012). Nesse

\footnotetext{
${ }^{22}$ Conjunto de organizações das entidades corporativas voltadas para o treinamento profissional, assistência social, consultoria, pesquisa e assistência técnica. Fazem parte atualmente do sistema S: Serviço Nacional de Aprendizagem Industrial (Senai); Serviço Social do Comércio (Sesc); Serviço Social da Indústria (Sesi); e Serviço Nacional de Aprendizagem do Comércio (Senac). Disponível em http://www12.senado.leg.br/noticias/glossariolegislativo/sistema-s Acesso em 28 de nov. de 2014.
} 
período, ganham destaque os programas intermediação da mão-de-obra, de qualificação profissional e de geração de renda (SILVA e YAZBEK, 2012). E no ano de 1996, é criado o Plano Nacional de Qualificação do Trabalhador (PLANFOR), cujo objetivo era o desenvolvimento de ações de educação profissional, que permitissem a redução do desemprego, elevação da produtividade e diminuição da pobreza e desigualdade social (BRASIL, 2001).

Segundo Sousa e Pereira (2012), esses programas de qualificação profissional incorporam a dimensão subjetiva da empregabilidade, caracterizada pelo mérito, ao responsabilizar o indivíduo pela conquista de atributos, isto é, competência profissional, que promovam sua inserção em um mercado competitivo. Nesse sentido, percebe-se que as políticas ativas no contexto brasileiro passam a incorporar o ideário schumpeteriano, baseado na adaptação a uma sociedade competitiva. Também é possível apreender, que nesse período, a qualificação profissional já estava atrelada à questão da pobreza, como se tal medida, ao permitir o acesso ao mercado de trabalho precário e desprotegido, promoveria, por sua vez, bem-estar e a saída da situação de pobreza, sem levar em consideração outros mecanismos de proteção social. Para Barbosa (2007), as políticas ativas, compreendidas pela autora como atividades que geram renda em uma situação de não empregabilidade, podem ser mistificadas e compreendidas neste contexto como:

Geradoras de autonomia dos usuários porque promotoras do auto-emprego, paralelamente à associação dos demais como ações assistencialistas, referidas com certo sentido pejorativo desviando a questão da responsabilidade pública da sociedade com a inatividade temporária ou permanente como um direito universal (BARBOSA, 2007, p. 8).

Durante o governo Lula, as ações relacionadas ao combate do desemprego buscaram reformular aquelas já existentes, além de criar novas medidas, destinadas a grupos específicos, conforme determinado pelos organismos multilaterais (OLIVEIRA, 2012). No que concerne às ações de qualificação profissional, foi criado o Cadastro Nacional de Aprendizagem, com o objetivo de registrar as instituições de ensino profissional no país. No ano de 2003, foi formulado um conjunto de programas pelo governo federal, orientados pela lógica da empregabilidade e do empreendedorismo, dentre os quais é possível citar o Programa Nacional de Estímulo ao Primeiro Emprego (PNPE), voltado para jovens de baixa renda, e o Programa Economia Solidária em Desenvolvimento, considerado como um instrumento de combate à pobreza, no qual os trabalhadores se organizam coletivamente, por meio de cooperativas, associações e etc. (OLIVEIRA, 2012). E que posteriormente foi incluído no Plano Brasil Sem Miséria, constituindo como público-alvo as famílias em situação de extrema pobreza. 
De acordo com Barbosa (2007), a incorporação da economia solidária como política pública guia-se pelas ideias schumpeterianas, que condiciona o desenvolvimento econômico às ações inovadoras do indivíduo, que passa a incorporar a figura do empreendedor. Essa lógica passa a ser integrada também às medidas de qualificação profissional, que na conjuntura brasileira possuem pouca efetividade e historicamente estão desarticuladas com a realidade do mercado de trabalho, além de estarem atreladas a fatores como baixa escolaridade e destinação de profissões menos nobres às pessoas mais pobres (SOUSA e PEREIRA, 2012).

Nesta conjuntura, também se destaca a criação do Plano Nacional de Qualificação (PNQ), que intencionava a articulação entre as medidas de qualificação profissional e social. O PNQ possuía os seguintes objetivos: formação integral dos trabalhadores; elevação da produtividade; aumento da probabilidade de obtenção de emprego; aumento da probabilidade de permanência no mercado de trabalho; inclusão social, redução da pobreza, combate à discriminação e diminuição da probabilidade de vulnerabilidade social (BRASIL, 2003). Mais uma vez a pobreza e a redução da desigualdade aparecem associadas às medidas de qualificação profissional.

\subsection{Assistência social e inclusão produtiva: uma relação persistente}

Conforme demonstrado no capítulo anterior, apesar da longa e contraditória trajetória que a assistência social brasileira percorreu nas últimas décadas para ser considerada um direito e estabelecida como política pública e dever do Estado, não impediram que ainda hoje sua prática estivesse vinculada a uma lógica conservadora (SILVA, 2015). Ao realizar uma análise do SUAS no âmbito municipal, Silva (2015) afirma que existe no campo da proteção social básica, ofertada pelos CRAS, a predominância de ações relacionadas à transferência condicionada de renda, seja por meio de ações de cadastramento de usuários no Cadúnico para acesso ao Bolsa Família, controle das condicionalidades do programa e ações de inclusão produtiva. Essa tendência é corroborada pelos dados do CENSO SUAS, que demonstra que no período de 2011 a 2013, as principais situações identificadas no território de abrangência dos CRAS, podem ser resumidas conforme o gráfico seguinte: 


\section{Gráfico 1 -Situações frequentemente identificadas no território de abrangência dos} CRAS (2011 a 2013)

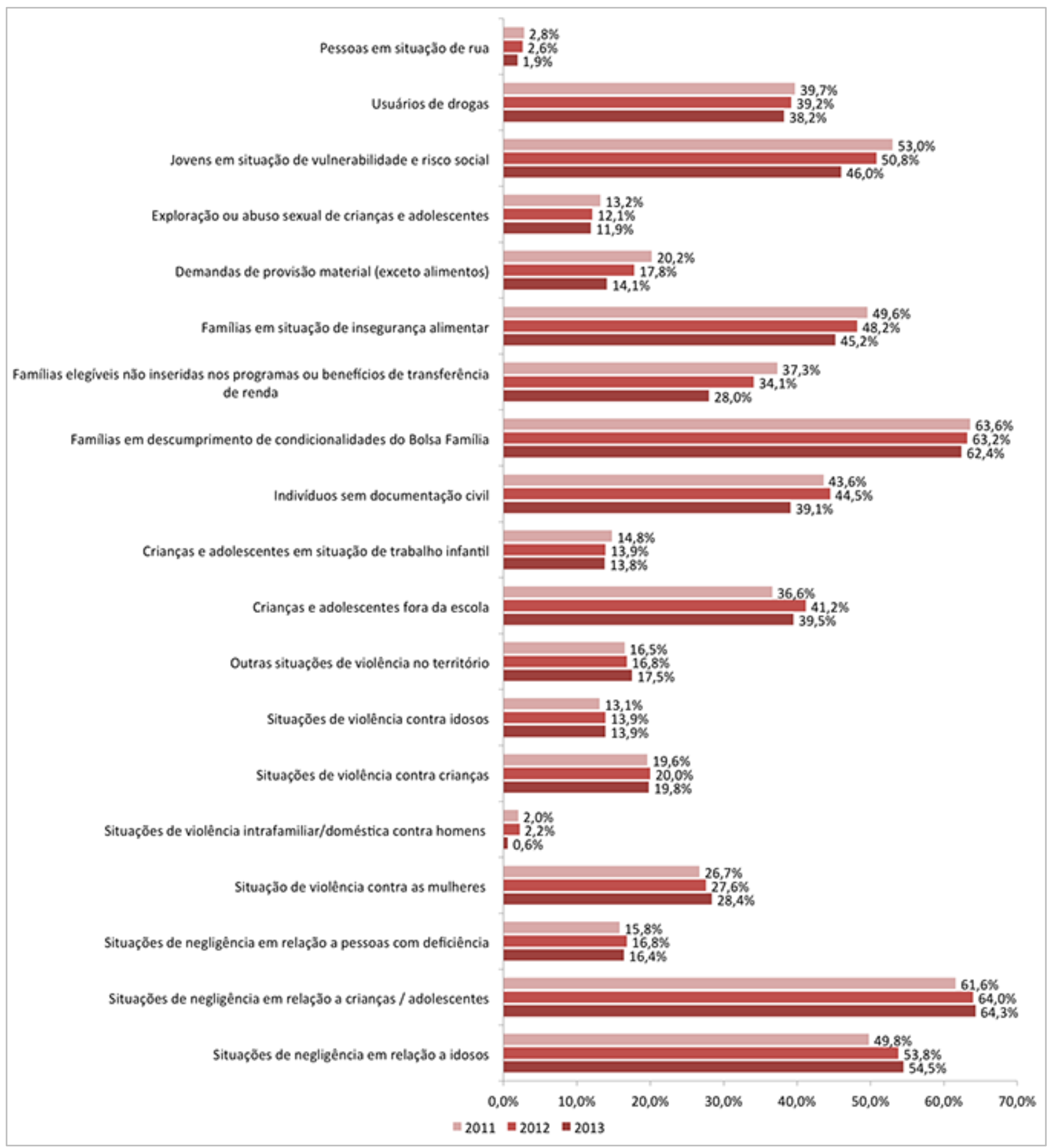

Fonte: Data Social CENSO SUAS 2013 - Secretaria de Avaliação e Gestão da Informação SAGI/MDS. Disponível em http://aplicacoes.mds.gov.br/sagi-data/METRO/metro ds.php?p id=494. Acesso em 12/08/2016.

Conforme é possível observar, uma das principais situações identificadas é com relação às famílias em descumprimento de condicionalidade do Programa Bolsa Família. A identificação dessas famílias pelos CRAS torna-se necessária, haja vista as recomendações presentes nas normativas da política de assistência social e do Programa Bolsa Família, que 
definem que as famílias em situação de descumprimento devem ser inseridas em acompanhamento pelos serviços socioassistenciais, por estarem em situação de vulnerabilidade ou risco social. Por trás dessa justificativa, que revela um fenômeno aparente, tem-se o fato que, na realidade, a política de assistência social passa a incorporar os mecanismos de focalização e de controle/fiscalização dos usuários, que baseados em uma perspectiva conservadora, reforçam a lógica de acumulação do capital. Nesse sentido,

Tais programas de transferência de renda focalizados e condicionados carregam consigo a armadilha que os transformam em verdadeiros sistemas executores de critérios e penalidades com códigos de controles, regras e mecanismos que lhe são próprios, cuja tecnicidade garante a "organização da fila" para recebimento de benefícios, além de focalizar e buscar ativar os mais pobres (CARNELOSSI, 2016, p 132).

O gráfico abaixo também evidencia essa característica, ao demonstrar que nos CRAS, as ações de busca ativa, planejamento e oferta de serviços e inserção no Serviço de Proteção e Atendimento Integral à Família (PAIF) vem priorizando beneficiários do Bolsa Família e famílias em situação de descumprimento de condicionalidade.

\section{Gráfico 2 - Ações realizadas pelos CRAS por público}

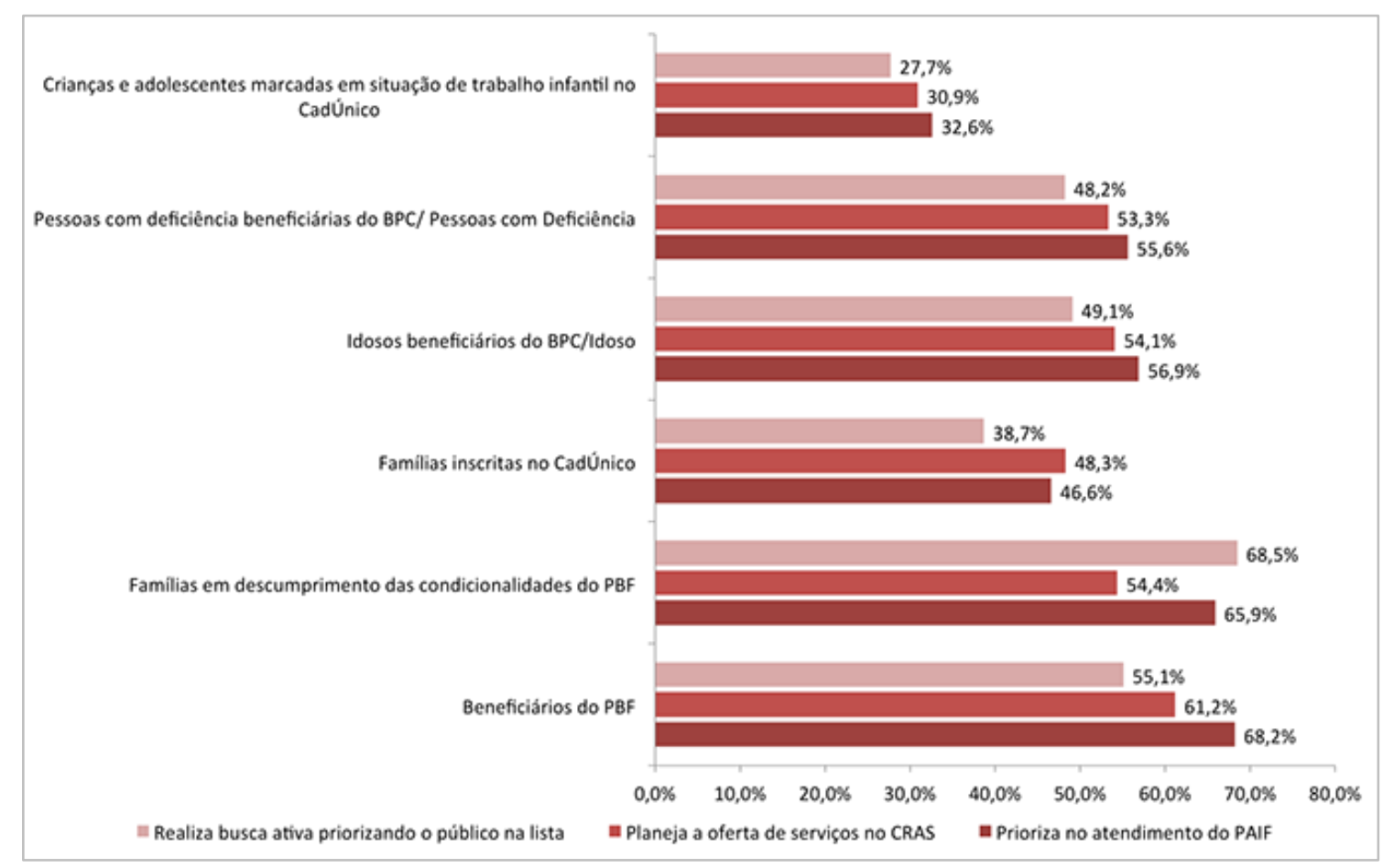

Fonte: Data Social CENSO SUAS 2013 - Secretaria de Avaliação e Gestão da Informação SAGI/MDS. Disponível em http://aplicacoes.mds.gov.br/sagi-data/METRO/metro ds.php?p id=494. Acesso em 12/08/2016. 
Com isso, tem-se também a incorporação pela política de assistência social do viés burocrático e tecnicista, que se baseia em mecanismos de controle, em detrimento de ações garantidoras de direitos (SILVA, 2015). De acordo com Boschetti, Teixeira e Salvador (2013), as ações relacionadas ao Programa Bolsa Família, como o controle das condicionalidades, o CadÚnico e aquelas que envolvem a priorização desse público, têm tomado conta do SUAS, no lugar de ações de caráter mais crítico, que possibilitem aos profissionais um trabalho mais espontâneo e criativo.

Conforme observado, os usuários que recebem Bolsa Família são designados como público prioritário de atendimento no âmbito da assistência social. Essa precedência também existe com relação às medidas de ativação para o trabalho desses usuários, por meio da chamada inclusão produtiva, geração de renda, qualificação profissional, etc. Essa tendência também pode ser notada no conteúdo do Projeto de Lei Federal nº 6021/2009, que recentemente, a Comissão de Trabalho, de Administração e Serviço Público da Câmara dos Deputados aprovou a proposta que condiciona a concessão do Bolsa Família à inscrição de pelo menos um integrante da família beneficiada em programa de qualificação profissional. $\mathrm{O}$ texto aprovado pelos deputados determina que o beneficiário do Bolsa Família deverá comprovar, no prazo de 90 dias, a inscrição e a participação em curso de educação profissional ou tecnológica e após o curso de qualificação, o currículo do profissional será incluído em cadastro de vagas das agências do trabalhador. $\mathrm{O}$ beneficiário que recusar mais de quatro propostas de trabalho ou começar a atuar como profissional liberal terá o benefício suspenso ${ }^{23}$.

Percebe-se que a proposta radicaliza o caráter punitivo que as condicionalidades já possuem e deixa mais clara as reais intenções destas, haja vista que as ações de acesso ao mundo do trabalho realizadas pela política de assistência social, seja diretamente ou através de sua mediação, são embebidas por ideias de alcance do protagonismo, autonomia e promoção social, que mascaram o real propósito dessas iniciativas, quais sejam, a responsabilização do indivíduo pela sua própria situação, por meio do trabalho, considerado o mecanismo ideal e que atribui mérito.

É sabido que a relação entre assistência social e trabalho é histórica, e permeia o desenvolvimento dessa política no Brasil, perpassando inclusive suas normativas. Apesar do avanço existente nos últimos anos com relação à conceituação e discussão das práticas relacionadas à assistência social, na tentativa de rompimento com a lógica da benesse, ainda

23 Disponível em http://www2.camara.leg.br/camaranoticias/noticias/ASSISTENCIA-SOCIAL/503099COMISSAO-CONDICIONA-BOLSA-FAMILIA-A-INSCRICAO-EM-CURSO-DE-QUALIFICACAOPROFISSIONAL.html. Acesso em 04 de julho de 2016. 
são comuns os equívocos com relação às suas atribuições e limites. A persistente correspondência ente ativação para o trabalho e assistência social demonstra que esses equívocos ainda se perpetuam.

De acordo com Silva (2013), são crescentes as ações municipais, de caráter fragmentando, pontual e isolado, que utilizam recurso do fundo de assistência social para promover geração de trabalho e renda. Essa prática é reforçada com o movimento do workfare na atualidade, que pode ser traduzido pelo incentivo ao trabalho ou à qualificação, em troca do recebimento de benefício ou serviço (COUTO, 2015). Conforme demonstram os gráficos seguintes, percebe-se que a maioria dos municípios brasileiros vem implantando ações de inclusão produtiva e qualificação profissional, sob mediação da política de assistência social.

Gráfico 3 - Percentual de municípios que desenvolve ações, programas, ou projetos de inclusão produtiva para geração de trabalho e renda (2011 a 2014)

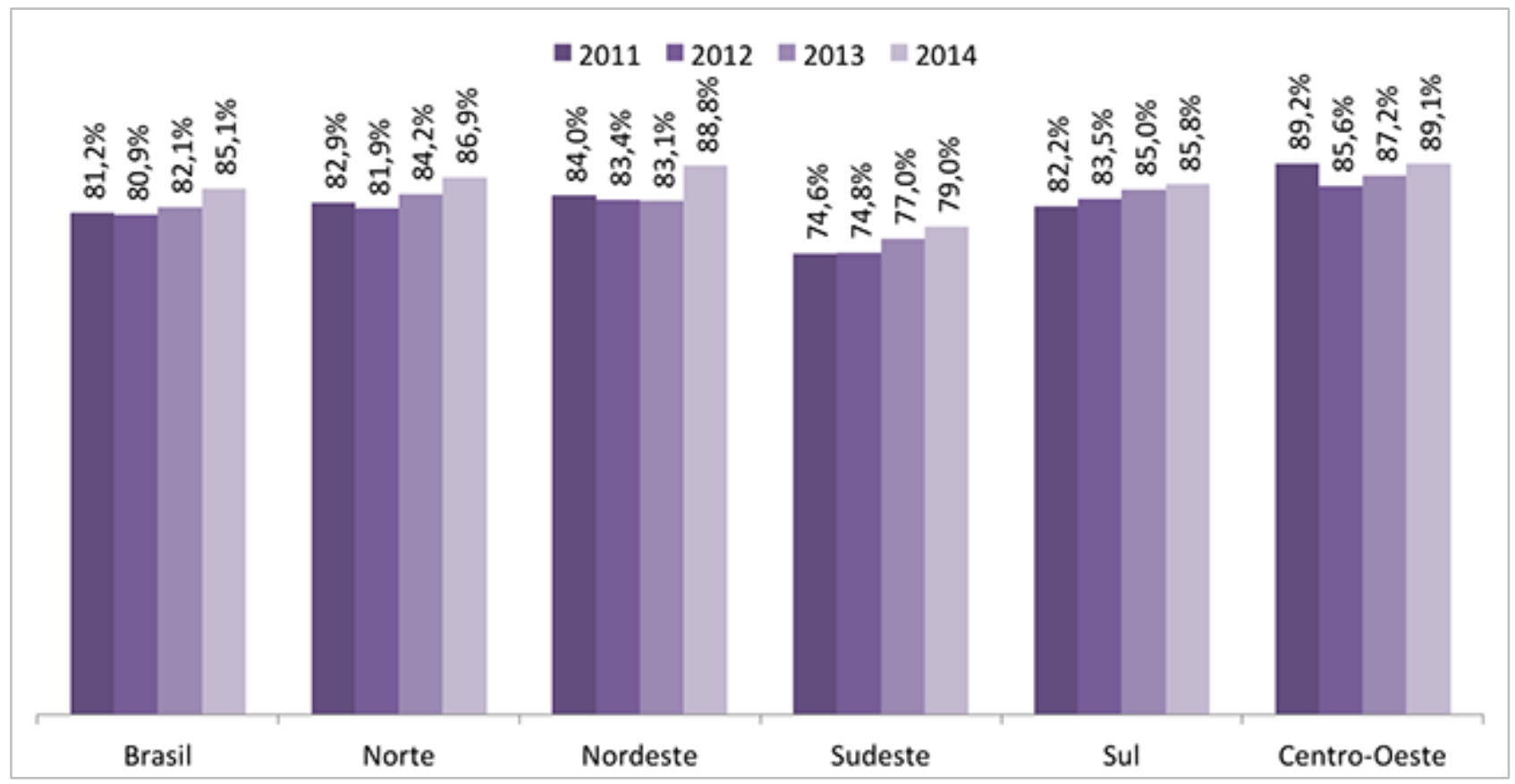

Fonte: Data Social CENSO SUAS 2013 - Secretaria de Avaliação e Gestão da Informação SAGI/MDS. Disponível em http://aplicacoes.mds.gov.br/sagi-data/METRO/metro_ds.php?p_id=494. Acesso em 01/09/2016. 
Gráfico 4 - Percentual de municípios que desenvolve ações, programas, ou projetos de qualificação ou capacitação profissional (2011 a 2014)

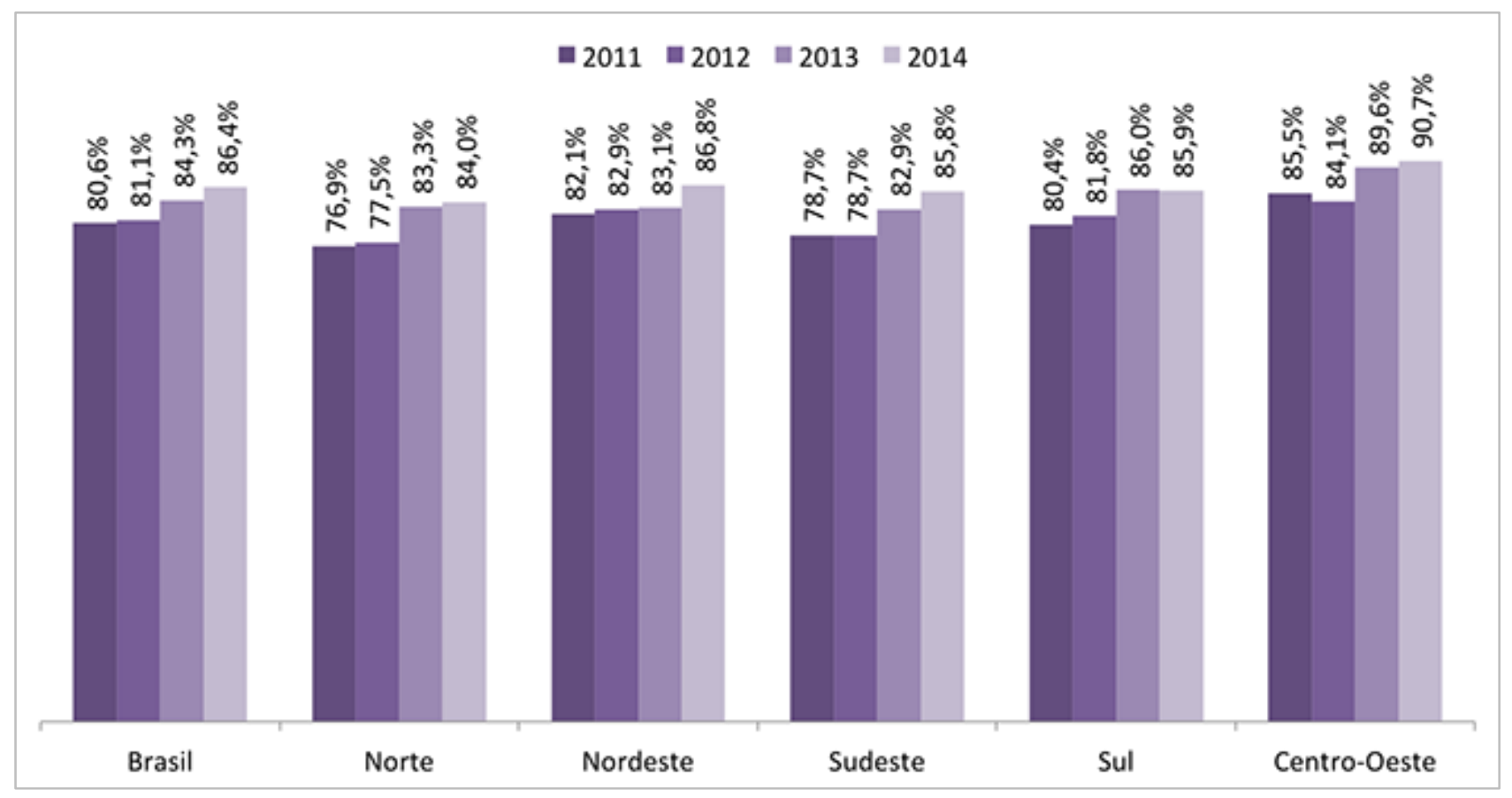

Fonte: Data Social CENSO SUAS 2013 - Secretaria de Avaliação e Gestão da Informação SAGI/MDS. Disponível em http://aplicacoes.mds.gov.br/sagi-data/METRO/metro ds.php?p id=494. Acesso em 01/09/2016.

A política de assistência social vem executando ações de ativação para o trabalho, que ocorrem basicamente de duas formas. A primeira, de maneira direta, isto é, são as unidades de assistência social, em geral os CRAS, tendo em vista suas atribuições no âmbito do SUAS, que ofertam as ações de inclusão produtiva ou qualificação profissional, como cursos de artesanato e outros tipos (SILVA, 2013). A segunda forma é realizada indiretamente, ou seja, refere-se aos encaminhamentos feitos pelas unidades de assistência social às instituições ou programas na área do trabalho. Os dados sobre a execução direta não estão disponibilizados pelo Ministério do Desenvolvimento Social e Combate à Fome (MDS), agora MDSA, entretanto, sabe-se que essas práticas ainda são comuns. Dessa forma, somente existem informações sobre a forma indireta, ainda que restritas, conforme demonstra o gráfico seguinte. 
Gráfico 5 - Percentual de municípios que encaminha os usuários da assistência social por oportunidades no mercado de trabalho

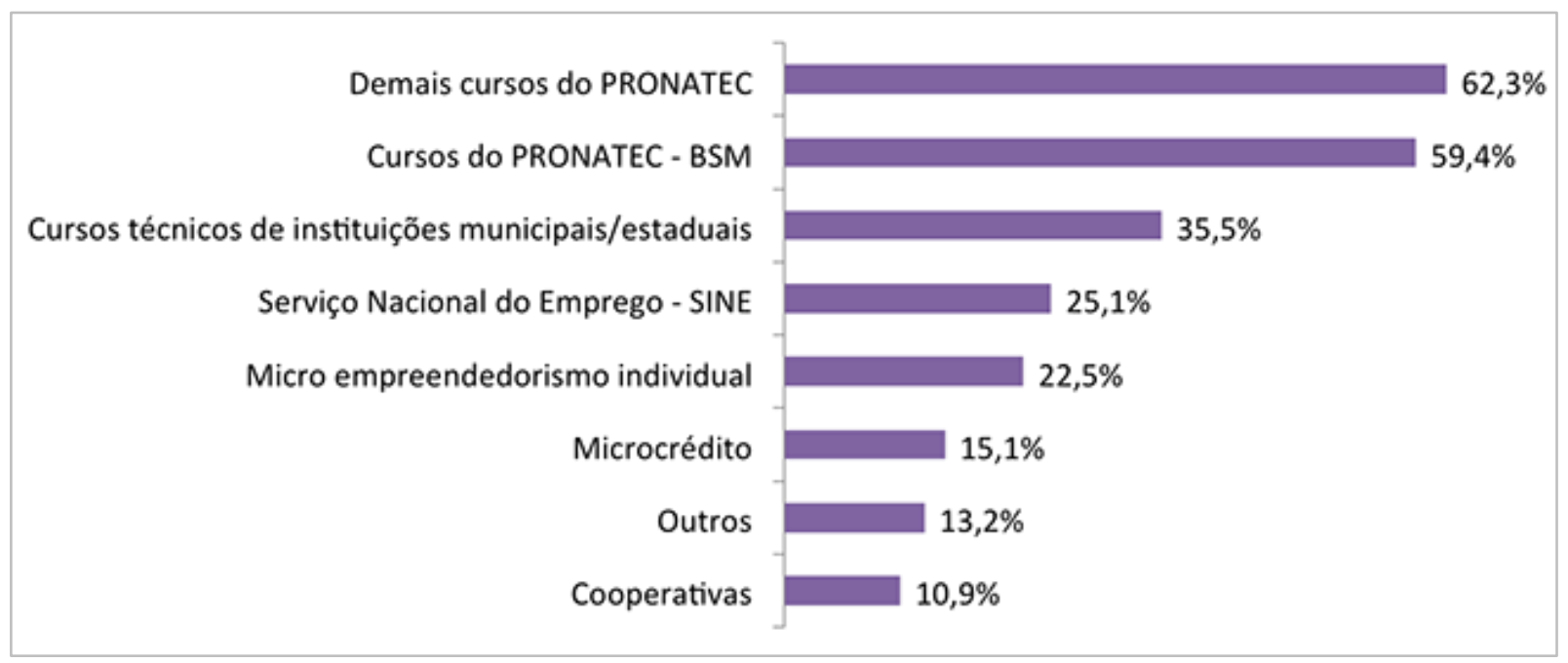

Fonte: Data Social CENSO SUAS 2013 - Secretaria de Avaliação e Gestão da Informação SAGI/MDS. Disponível em http://aplicacoes.mds.gov.br/sagi-data/METRO/metro ds.php?p id=494. Acesso em 01/09/2016

Percebe-se que a principal forma de encaminhamento tem se dado por meio do PRONATEC e do PRONATEC - BSM, com uma diferença percentual pequena. Em terceiro lugar estão os cursos técnicos de instituições municipais ou estaduais, o que demonstra que as ações de ativação indireta no âmbito da assistência social têm priorizado a qualificação profissional, no lugar do empreendedorismo, por exemplo. Neste contexto, o PRONATEC BSM é paradigmático para compreensão da tendência de incorporação da lógica do workfare pela política de assistência social, uma vez que, o programa de qualificação profissional é focalizado nos beneficiários do Bolsa Família.

\subsection{O PRONATEC - BSM como estratégia de ativação dos demandantes da política de assistência social}

O Programa Nacional de Acesso ao Ensino Técnico e Emprego (PRONATEC) foi criado no ano de 2011, pelo governo de Dilma Rousseff. O programa tem como finalidade expandir, interiorizar e democratizar a oferta de cursos de educação profissional e tecnológica no país, a partir dos seguintes objetivos: expansão e democratização da oferta de cursos de educação profissional técnica de nível médio; apoio a expansão da rede física de atendimento da educação profissional e tecnológica; ampliação das oportunidades educacionais dos trabalhadores, por meio da qualificação profissional; estímulo à difusão de recursos 
pedagógicos; fomento à articulação entre a política de educação profissional e tecnológica e as políticas de geração de trabalho, emprego e renda (BRASIL, 2011).

Ao contrário dos programas anteriores, o PRONATEC não estabelece em seus objetivos a redução da pobreza ou desigualdade social. Entretanto, a relação com um público específico aparece na definição de um dos segmentos que terá atendimento prioritário ao programa, que são os beneficiários dos programas federais de transferência de renda, ou seja, beneficiários do Programa Bolsa Família (PBF) e do Benefício de Prestação Continuada (BPC).

A oferta de vagas de qualificação profissional a esse público é fundamentada no Plano Brasil Sem Miséria, que tem como um dos eixos a inclusão produtiva, considerada como um estímulo à geração de renda, por meio da oferta de orientação profissional, cursos de qualificação e intermediação de mão-de-obra. Dessa forma, a execução do PRONATEC - BSM se relaciona com a política de assistência social, por meio do Programa Nacional de Promoção do Acesso ao Mundo do Trabalho (ACESSUAS/TRABALHO), que conforme visto no capítulo anterior tem como principal objetivo a promoção dos usuários da assistência social ao mundo do trabalho.

Na conjuntura atual, do governo espúrio de Michel Temer, foi ventilada recentemente a notícia $^{24}$ de parceria entre o Ministério do Desenvolvimento Social e Agrário (MDSA) com a Organização Internacional do Trabalho (OIT), com o objetivo de promover a inclusão produtiva, através do empreendedorismo e da aprendizagem. De acordo com as informações divulgadas, estão sendo planejadas novas ações nessa área para os beneficiários do Bolsa Família, além de estar sendo reavaliado o PRONATEC - BSM. Devido à orientação ideológica conservadora e de extrema direita do governo atual, apreende-se que existe uma tendência de fortalecimento da relação entre as ações de ativação para o trabalho com a política de assistência social, e, por consequência, de expansão da lógica do workfare.

Face ao exposto, tendo em vista o objetivo desta dissertação, ao utilizar o PRONATEC-BSM como estudo de caso, dada as especificidades de sua configuração, que expressam no contexto brasileiro a relação contraditória entre assistência social e trabalho, por meio da ativação dos beneficiários do Bolsa Família, foram elaboradas as seguintes tabelas, cada uma apresentado uma dimensão de análise do programa. Cada tabela apresenta três colunas, a primeira refere-se aos indicadores utilizados, a segunda possui informações do programa e a terceira coluna apresenta o resumo da análise de cada um dos indicadores.

\footnotetext{
${ }^{24}$ Disponível em http://mds.gov.br/area-de-imprensa/ultimas-noticias\#b_start=0. Acesso em 01/09/2016.
} 
Tabela 1 - Dimensão de Análise: Configuração e abrangência dos direitos garantidos pelo

PRONATEC - BSM

\begin{tabular}{|c|c|}
\hline \multicolumn{1}{|c|}{ INDICADORES } & INFORMAÇŌES DO PROGRAMA \\
\hline \multirow{3}{*}{ Público que se destina } & $\begin{array}{l}\text { Beneficiários do Programa Bolsa Família (PBF), } \\
\text { beneficiários do Benefício de Prestação Continuada } \\
\text { (BPC), e pessoas cadastradas ou em processo de } \\
\text { cadastramento no Cadastro Único para Programas } \\
\text { Sociais do Governo Federal (CadÚnico). }\end{array}$ \\
\hline
\end{tabular}

CONFIGURAÇÃO E ABRANGÊNCIA DOS DIREITOS GARANTIDOS PELO PRONATEC - BSM BPC; Estar cadastrado ou em cadastramento no CadÚnico. de "baixa renda".
O PRONATEC-BSM se destina a um público específico, que é definido a partir de um critério de renda, pois para uma família ser beneficiada no PBF, é preciso ter uma renda per capita de até $\mathrm{R} \$ 170$, ou seja, ser considerada pobre ou extremamente pobre segundo a linha de pobreza definida como critério para acesso ao PBF. O mesmo se aplica aqueles que estão ou serão inseridos no Cadúnico, pois nesse caso, o Cadastro permite a inserção daquelas famílias, consideradas de "baixa renda", isto é, com renda per capita mensal de até meio salário mínimo ou famílias com renda total de até três salários mínimos. Portanto, é possível afirmar que o público a que se destina é aquele em situação de pobreza, ou

Assim como foi colocado no item anterior, como o público do PRONATEC-BSM é específico, os critérios de acesso ao programa acabam sendo afetados por um corte de renda implícito. Nesse sentido, o que fundamenta o critério de acesso ao programa é ter uma renda considerada baixa.

O PRONATEC-BSM é focalizado na pobreza e extrema pobreza, pois é destinado àquelas pessoas pertencentes às famílias com corte de renda específico.

Segundo o Caderno de Resultados do Plano Brasil Sem Miséria (2014), dentre a quantidade total de matrículas nos três anos, $67 \%$ são mulheres e $48 \%$ tem idade entre 18 e 29 anos. Os únicos dados disponíveis sobre o PRONATEC-BSM são aqueles relacionados a quantidade de matrículas. Contudo,

Em 2012, foram 261.071 matrículas no Pronatec-BSM no Brasil. No ano de 2013, 583.109, e em 2014, um total de 634.178.

(Fonte: http://aplicacoes.mds.gov.br/sagi/) não há o quantitativo de matrículas por perfil, isto é, quantos recebem $\mathrm{PBF}$, quantos estão somente inseridos no Cadúnico. Somente é possível comparar a quantidade de matrículas com a quantidade de famílias inseridas no Cadastro Único ou a quantidade de famílias beneficiárias do PBF. Por exemplo, em 2012 existiam aproximadamente 24 milhões de famílias cadastradas com renda per capita de até meio salário mínimo, em 2013, também 


\begin{tabular}{|c|c|c|}
\hline & & $\begin{array}{l}24 \text { milhões, e em } 2014 \text {, por volta de } 22 \text { milhões. Ao } \\
\text { comparar essa quantidade com o total de matrículas } \\
\text { do PRONATEC/BSM durante os três anos, percebe- } \\
\text { se que os números são discrepantes. O mesmo } \\
\text { acontece ao realizar a comparação com a quantidade } \\
\text { de famílias beneficiárias do PBF. Portanto, é possível } \\
\text { afirmar que o programa tem uma abrangência } \\
\text { pequena com relação ao público a que se destina. }\end{array}$ \\
\hline $\begin{array}{l}\text { Articulação com outras políticas } \\
\text { sociais }\end{array}$ & $\begin{array}{l}\text { O PRONATEC/BSM se articula principalmente com a } \\
\text { política de educação e assistência social. }\end{array}$ & $\begin{array}{l}\text { O PRONATEC-BSM é articulado com a política de } \\
\text { educação por ter como objetivo precípuo a ampliação } \\
\text { da oferta de cursos de educação profissional e } \\
\text { tecnológica. Os cursos do programa também são } \\
\text { ofertados por instituições educacionais, com exceção } \\
\text { do Sistema S, que possui determinadas } \\
\text { especificidades. Com relação à política de } \\
\text { assistência social, o PRONATEC-BSM se relaciona, } \\
\text { por meio da efetivação da matrícula nos cursos } \\
\text { disponíveis, que são realizadas pelos Centros de } \\
\text { Referência de Assistência Social (CRAS), e, em } \\
\text { menor número, pelos Centros de Referência } \\
\text { Especializados de Assistência Social (CREAS). } \\
\text { Como existe uma contradição histórica entre trabalho } \\
\text { e assistência social, essa política passa a assumir a } \\
\text { atribuição de ativação dos beneficiários do PBF, por } \\
\text { meio do PRONATEC-BSM. }\end{array}$ \\
\hline $\begin{array}{c}\text { É executado sob a forma do } \\
\text { direito ou a partir de outro } \\
\text { aspecto }\end{array}$ & $\begin{array}{l}\text { A execução do PRONATEC/BSM está vinculada com a } \\
\text { ativação para o trabalho. }\end{array}$ & $\begin{array}{l}\text { O PRONATEC-BSM relaciona diretamente pobreza } \\
\text { com medidas denominadas de inclusão produtiva, } \\
\text { que são vistas como principal "porta de saída" da } \\
\text { assistência social. Portanto, o programa reforça a } \\
\text { lógica liberal, ao colocar o trabalho como principal } \\
\text { mecanismo de proteção social da população pobre, } \\
\text { que sofre também com o aspecto moralizante da } \\
\text { ação, isto é, o reforço da responsabilidade individual } \\
\text { pela situação vivenciada e a necessidade de } \\
\text { melhorar suas capacidades e potencialidades por } \\
\text { meio da qualificação profissional. }\end{array}$ \\
\hline
\end{tabular}

Fonte: Elaboração Própria

Tabela 2 - Dimensão de Análise: Gestão do PRONATEC - BSM

\begin{tabular}{|c|c|c|}
\hline \multicolumn{2}{|c|}{ GESTÃO DO PRONATEC - BSM } \\
\hline INDICADORES & INFORMAÇÕES DO PROGRAMA & \multicolumn{1}{|c|}{ ANÁLISE } \\
\hline Relação entre Estado e mercado & Fortalecimento do mercado privado de ensino. & $\begin{array}{l}\text { Em 2013, os cursos do PRONATEC-BSM também } \\
\text { passaram a ser ofertados pela rede privada de } \\
\text { ensino. Essa mudança suscita a discussão sobre o } \\
\text { repasse de recursos públicos a unidades de ensino } \\
\text { particulares conveniadas, que por sua natureza, } \\
\text { visam primeiramente o lucro. Percebe-se então que }\end{array}$ \\
\hline
\end{tabular}




\begin{tabular}{|l|l|l|}
\hline & $\begin{array}{l}\text { o programa passou a incrementar o mercado privado, } \\
\text { o que acentuou a relação de mercadorização da } \\
\text { educação. }\end{array}$ \\
\hline
\end{tabular}

Fonte: Elaboração Própria

Tabela 3 - Dimensão de Análise: Características da ativação para o trabalho do PRONATEC - BSM

\begin{tabular}{|c|c|c|}
\hline \multicolumn{3}{|c|}{ CARACTERÍSTICAS DA ATIVAÇÃO PARA O TRABALHO DO PRONATEC - BSM } \\
\hline INDICADORES & INFORMAÇŌES DO PROGRAMA & ANÁLISE \\
\hline Motivação política & Fundamentada no Plano Brasil Sem Miséria. & $\begin{array}{l}\text { Objetivo de erradicar a extrema pobreza no Brasil por } \\
\text { meio de um conjunto de ações, na qual se destaca a } \\
\text { denominada inclusão produtiva. }\end{array}$ \\
\hline $\begin{array}{l}\text { Capacidade de inclusão no } \\
\text { mercado de trabalho }\end{array}$ & $\begin{array}{l}\text { Gargalo entre a conclusão do curso de qualificação e } \\
\text { a conquista de emprego. }\end{array}$ & $\begin{array}{l}\text { Não há dados quantitativos sobre o gargalo existente } \\
\text { entre a conclusão do curso pelos participantes e a } \\
\text { inserção no mercado de trabalho. Existem poucas } \\
\text { pesquisas de avaliação sobre o PRONATEC-BSM } \\
\text { que demonstram essa tendência, além de ser uma } \\
\text { característica das políticas de ativação apontada por } \\
\text { diversos autores. }\end{array}$ \\
\hline Eficácia frente à pobreza & Baixa & $\begin{array}{l}\text { Além de existir um distanciamento entre a conclusão } \\
\text { do curso do PRONATEC-BSM e a entrada no } \\
\text { mercado de trabalho, o trabalho em si não pode ser } \\
\text { entendido como principal mecanismo de proteção } \\
\text { social na atualidade, dada a configuração que } \\
\text { adquire no capitalismo, isto é, baseado na exploração } \\
\text { e na alienação. Portanto, a entrada no mercado de } \\
\text { trabalho não garante a saída da situação de pobreza. }\end{array}$ \\
\hline Nível de sanção ao participante & $\begin{array}{c}\text { Não existe sanção ao participante que não conclui o } \\
\text { curso do PRONATEC-BSM, assim como, para o } \\
\text { usuário da assistência social que não adere ao } \\
\text { programa. }\end{array}$ & $\begin{array}{l}\text { Apesar de não existir sanção explícita no } \\
\text { PRONATEC-BSM, é importante destacar que existe } \\
\text { historicamente uma sanção moral sobre o pobre } \\
\text { desempregado, responsabilizando-o por sua } \\
\text { situação. A meritocracia e o resgate do primado } \\
\text { liberal do trabalho podem ser vistos claramente } \\
\text { nessa dinâmica. }\end{array}$ \\
\hline
\end{tabular}

Fonte: Elaboração Própria

De acordo com a análise realizada, percebe-se que uma das principais características do PRONATEC-BSM é relacionar a pobreza com a ativação para o trabalho. Essa relação não é novidade e também tem acompanhado as políticas de ativação em outros países, ressalvadas as especificidades de cada realidade. Essa tendência está relacionada com as características da proteção social na contemporaneidade, que destina uma pequena parcela da população benefícios de valores baixos, além de classificar os beneficiários entre capazes para o trabalho 
e não capazes (ERANSUS, 2005). Para aqueles considerados como capazes é estabelecido um conjunto de medidas de ativação, que em alguns países são definidas como obrigatórias. No Brasil, o PRONATEC-BSM não exige obrigatoriedade de participação do público do programa nos cursos de qualificação profissional oferecidos. Todavia, é perceptível que o programa tem o objetivo de ativar os pobres aptos para o trabalho, que são beneficiários de transferência de renda e usuários da política de assistência social.

Dada a sua configuração e ao público que se destina, o PRONATEC-BSM suscita a importância sobre a discussão da focalização, tendo em vista que reforça esse mecanismo ao se destinar aqueles considerados pobres e extremamente pobres. Pereira-Pereira e Stein (2010) afirmam que na focalização, as preferências individuais se sobrepõem às necessidades sociais, e o mérito é priorizado em detrimento do direito. A ideia dos defensores de estratégias de focalização, baseia-se na concepção que esta seria a opção mais racional para a aplicação de recursos escassos, que ao serem direcionados aos grupos sociais específicos, promoveriam uma maior eficácia (PEREIRA-PEREIRA e STEIN, 2010). Para Eransus (2006), a ideia de concentrar os recursos escassos naqueles que mais necessitam, não se destina somente aos pobres, mas também a outros grupos específicos, sobretudo aqueles que são considerados como público de políticas de ativação, como os desempregados de longa duração, jovens sem emprego, recebedores de prestação assistencial e outros. Portanto, de maneira geral, é possível apreender que as medidas de ativação incorporam largamente a focalização e reforçam essa lógica.

Devido ao fato do PRONATEC-BSM ser um programa que focaliza suas ações na população considerada em situação de pobreza e extrema pobreza, que recebe ou não benefícios de transferência de renda, existe uma articulação estratégica com a política de assistência social. Atualmente, a seleção e a matrícula dos possíveis participantes do PRONATEC-BSM é realizada preferencialmente nos Centros de Referência de Assistência Social (CRAS), e, em menor medida, nos Centros de Referência Especializado de Assistência Social (CREAS), ambos equipamentos públicos que ofertam serviços socioassistenciais. De acordo com Souza (2013), desde 2007, resultados de pesquisa demonstram que são utilizados recursos da assistência social em ações de inclusão produtiva, que são realizadas, em maior parte, por meio da oferta de cursos de capacitação para inserção no mercado de trabalho (SOUZA, 2013). O argumento utilizado para justificar essas ações, é o da promoção da autonomia, assim como, a melhora da autoestima dos usuários. 
Para se ter uma noção do alcance das ações de qualificação profissional no âmbito da política de assistência social, no que se refere ao PRONATEC-BSM, é preciso saber a abrangência que o programa possui. O principal dado disponível sobre a abrangência, é a quantidade de matrículas realizadas a cada ano, no Brasil e por região, a partir do ano de $2012^{25}$. Entretanto, para Boschetti (2009), esse indicador apresentado de maneira isolada não demonstra a amplitude que o programa possui, por isso, o gráfico abaixo compara a quantidade de matrículas do PRONATEC-BSM, com a quantidade do público que o programa se propõe a alcançar.

\section{Gráfico 6 - Comparação entre quantidade de matrículas do PRONATEC-BSM com a quantidade de famílias inseridas no CadÚnico e famílias beneficiárias do PBF (2012 a 2014)}

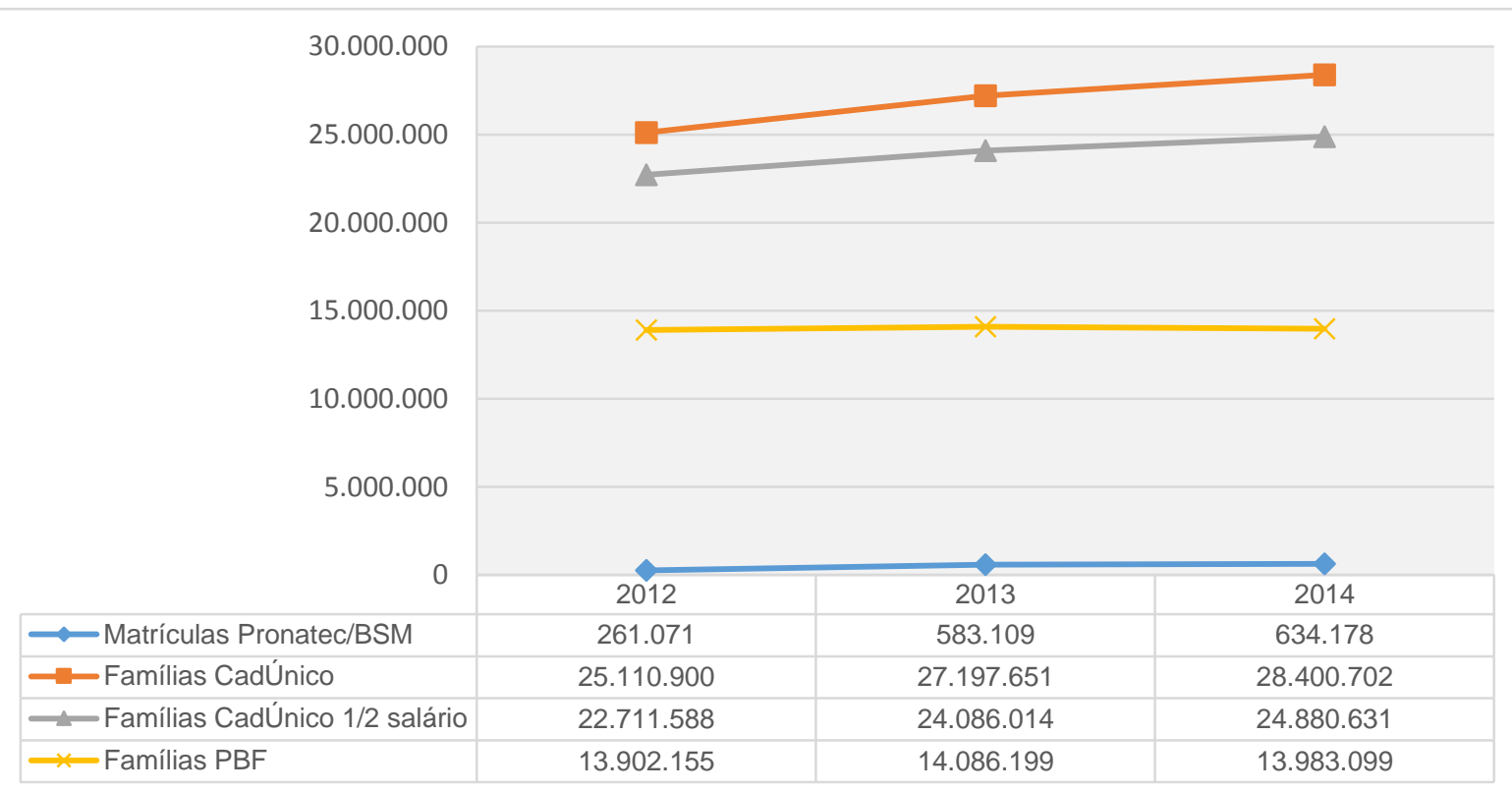

Fonte: Painel de Conjuntura e Programas Sociais - Secretaria de Avaliação e Gestão da Informação SAGI/MDS. Data Social - Secretaria de Avaliação e Gestão da Informação SAGI/MDS. Disponível em http://aplicacoes.mds.gov.br/sagi/ Acesso em 20/04/2016.

Notas: A quantidade de famílias inscritas no CadÚnico e de famílias beneficiárias do PBF tem como referência o mês de dezembro de cada ano.

A quantidade de famílias beneficiárias do PBF em 2014 corresponde a folha de pagamento do mês 09/2014.

A quantidade de famílias inscritas no CadÚnico em 2014 corresponde ao espelho do Cadastro de 07/2014.

\footnotetext{
${ }^{25}$ Até a data de elaboração desta dissertação, os dados oficiais disponíveis sobre a quantidade de matrículas realizadas no PRONATEC-BSM abrangiam somente os anos de 2012 a 2014, não existindo informações mais recentes disponibilizadas pela SAGI - MDSA.
} 
Gráfico 7 - Quantidade de matrículas do PRONATEC-BSM por região (2012 a 2014)

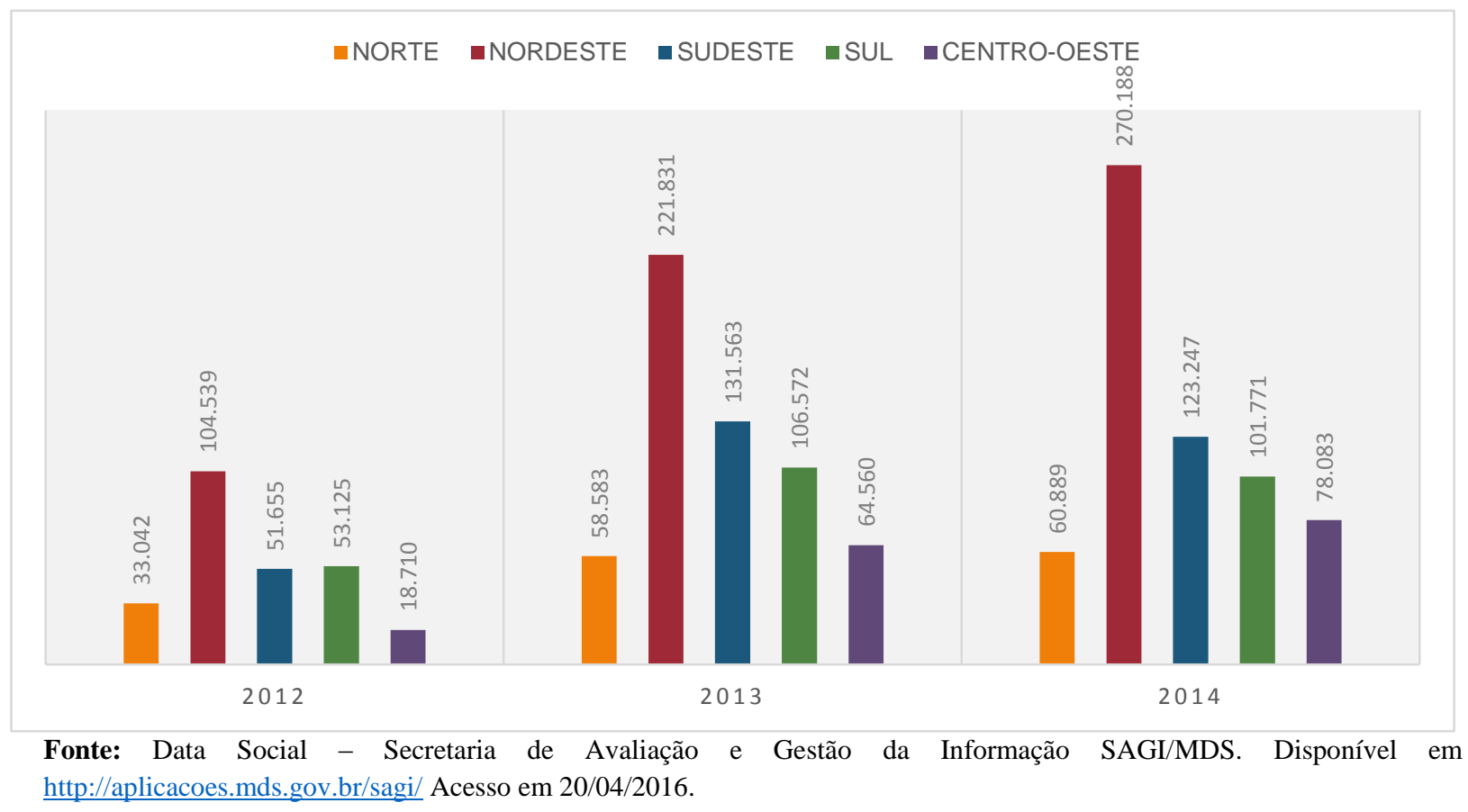

A partir da análise das informações presentes nos gráficos, percebe-se que a quantidade de famílias inscritas no CadÚnico e a quantidade de famílias beneficiárias do PBF, é drasticamente superior a quantidade de matrículas do PRONATEC-BSM, em cada um dos três anos apresentados. Esse número é ainda mais discrepante ao comparar a quantidade de matrículas com a quantidade de pessoas inscritas no CadÚnico e pessoas beneficiárias do PBF, portanto, é possível afirmar que o PRONATE-BSM possui uma baixa abrangência. Além disso, dada a escassez dos dados disponibilizados, não há como saber o perfil das pessoas matriculadas, isto é, quantas estão inseridas no CadÚnico mas não são beneficiárias de transferência de renda, sua renda, ou quantas recebem o PBF. As informações disponíveis presentes no Caderno de Resultados do Plano Brasil Sem Miséria (2014), mostram apenas que a quantidade total de matrículas no PRONATEC - BSM nos três anos refere-se ao seguinte percentual: $67 \%$ são mulheres e $48 \%$ tem idade entre 18 e 29 anos.

A Secretaria de Avaliação e Gestão da Informação (SAGI), do MDSA, realizou avaliação do PRONATEC-BSM, para fins de aprimoramento na implementação do programa. Os resultados demonstram que o PRONATEC-BSM não está atingindo o que denominam como o grupo dos mais pobres entre os pobres, ficando ainda restrito àqueles que possuem renda mais alta no CadÚnico (BRASIL, 2014). Esse resultado demonstra que o PRONATEC-BSM 
também não tem cumprido satisfatoriamente o papel a que se propõe na focalização da população em situação de pobreza e extrema pobreza.

Outro resultado apontado no estudo de caso sobre o PRONATEC-BSM, é que a inserção produtiva no mercado de trabalho formal da população pobre e extremamente pobre, ainda está longe de ser alcançada (BRASIL, 2014), apesar de não existirem dados concretos que mostrem a quantidade de pessoas que conseguiram emprego após a qualificação. Essa é uma tendência que também tem estado presente nas políticas de ativação de outros países. Segundo Eransus (2006), existem evidências empíricas que mostram as limitações dos programas de ativação em realizar a inserção laboral das pessoas em situações mais intensas de exclusão. Nesse sentido, para Durana e Eransus (2007), as pessoas que estão num nível maior de deterioração pessoal e social não podem cumprir com o que é estabelecido pelos programas de ativação, o que pode implicar num risco crescente de desproteção social.

De acordo com Souza (2013), os motivos que levam a manutenção dos cursos de qualificação, como o PRONATEC-BSM, ainda que a relação entre capacitados e inseridos no mercado de trabalho seja baixa, pode ser atribuído ao baixo custo financeiro, e, por contribuírem para fortalecimento dos aspectos subjetivos de autoestima dos usuários da política de assistência social. Percebe-se então que o PRONATEC-BSM falha em ativar a população pobre para o trabalho. Com isso, a manutenção do programa também pode ser justificada pelo forte apelo político que o PRONATEC possuía para o governo anterior, além de ser uma estratégia importante de reforço da focalização, que é amplamente recomendada pelos organismos internacionais, além de ser uma forma moralizante de garantir que aqueles que recebem benefícios de transferência de renda e/ou são usuários da assistência social, devem buscar outras formas de prover seu sustento.

A análise demonstra que o PRONATEC-BSM não possui muitas inovações se comparado com programas anteriores, como o PLANFOR, do governo de Fernando Henrique Cardoso, e o PNQ, criado durante o governo Lula, devido ao enfoque dado aos Cursos de Formação Inicial e Continuada, em detrimento de investimento na política de educação como um todo. Devido a situação da educação no contexto neoliberal, há uma forte tendência de precarização e privatização do ensino, e uma ausência na garantia de formação de qualidade, que não prepara a população para uma melhor colocação no mercado de trabalho. Somam-se a isso, fatores estruturais, inerentes a própria dinâmica do capital, como a necessidade de um exército industrial de reserva, a lógica imperativa do individualismo, do lucro e da visão da educação como mercadoria. Diante dessa conjuntura, o gargalo existente na educação formal 
não é passível de ser suprido pelos cursos do PRONATEC-BSM, que não promovem efetivamente a melhoria da qualificação dos trabalhadores.

Os cursos do PRONATEC-BSM são oferecidos pelas redes públicas e pelo Sistema S, e no ano de 2013, as instituições privadas também passaram a ofertar os cursos, mediante parceria com o governo federal. Até o momento, não existem informações disponíveis sobre o valor repassado a essas instituições. De acordo com Iamamoto (2008), existe no Brasil uma herança histórica de favorecimento dos interesses privados, no qual, o uso privado de recursos públicos é um exemplo dessa relação, que sob incremento do neoliberalismo, promove o impedimento à consolidação de uma cidadania forte e universal. Portanto, o PRONATEC-BSM reforça essa lógica ao privilegiar o setor privado. Outra problemática, deve-se ao fato da oferta dos cursos pelo Sistema S, que é formado por organizações do setor produtivo, e, por isso, possui uma ideologia privada de ensino. Segundo Mészáros (2008), a classe dominante impõe aos trabalhadores uma educação alienante, que tem como objetivo a dominação. Nesse sentido, o autor coloca a necessidade da educação ser um instrumento libertador, que permita ao trabalhador transformar a realidade.

A partir da análise realizada, é possível apreender que o PRONATEC-BSM demonstra e ao mesmo tempo reforça duas tendências presentes na política de assistência social na atualidade: a primeira, de focalização de seus serviços, programas e projetos naqueles beneficiários de transferência condicionada de renda; e a segunda, da crescente incorporação pela assistência social da atribuição de promover o acesso de seus usuários ao mercado de trabalho, a denominada ativação, seja direta ou indiretamente. Portanto, percebe-se que há um adensamento da lógica do workfare nas políticas sociais, sobretudo na política de assistência social, existindo uma possibilidade significativa de expansão dessa tendência, tendo em vista a conjuntura política e econômica atual. 


\section{CONSIDERAÇÕES FINAIS}

Esta dissertação teve como objetivo analisar as contradições, concepções e tendências presentes na política de assistência social brasileira, que estivessem relacionadas com a lógica do workfare (bem-estar em troca de trabalho) e de mecanismos de ativação de seus demandantes. A análise e discussão das categorias centrais e o estudo de caso sobre o PRONATEC - BSM, permitiram que fossem realizadas algumas considerações, que à guisa de conclusão, apresentam-se como reflexões importantes, dada a radicalização das expressões da questão social na contemporaneidade e as respostas do Estado capitalista frente a isso.

A primeira reflexão que se apresenta é com relação ao avanço da lógica do workfare na atualidade, isto é, da obrigatoriedade ou da ode ao trabalho em troca de proteção social, o que perpassa mudanças na forma de regulação do Estado capitalista, que passa a ter um viés schumpeteriano, e, concomitantemente na configuração dada às políticas sociais, que tornamse cada vez mais mercadorizáveis e deixam de se guiar pelo imperativo da satisfação das necessidades humanas. Uma das políticas sociais que vem incorporando com mais nitidez essa tendência é a assistência social, por meio da relação com as políticas ou medidas de ativação, haja vista sua contradição histórica com o trabalho. Essa tendência acirra a concepção subjacente de que existem indivíduos merecedores e não merecedores de assistência, portanto, baseada no mérito individual.

No contexto brasileiro, dada a conjuntura econômica e política, que conformaram o desenvolvimento do Estado social no país, essa configuração apresenta-se de maneira diversa daqueles países do capitalismo central, o que, no entanto, não significa que não exista. Historicamente, a exploração da força de trabalho no Brasil foi marcada pela superexploração, pela desregulamentação e informalidade, existindo durante longo período a predominância de políticas ativas, em detrimento daquelas consideradas passivas. Apesar disso, a eficiência dessas políticas, principalmente daquelas relacionadas à qualificação profissional, implementadas em diferentes governos, é questionável a partir de diferentes ângulos, como é possível observar na discussão realizada nesta pesquisa.

A relação tensionada entre trabalho e assistência social existe desde os primórdios de seu surgimento. No Brasil, o desenvolvimento da política de assistência social foi marcado por ações pontuais e fragmentadas, amparadas na perspectiva da benesse. Somente após um longo período é que a assistência social se estabeleceu enquanto direito e política de seguridade social, o que não garantiu que sua regulamentação e execução fossem desprovidas de contradição e 
dificuldade, sobretudo no que concerne à sua relação com o trabalho. De acordo com os resultados da pesquisa realizada, a assistência social na contemporaneidade passa a ter cada vez mais ações tecnicistas e burocráticas, pautadas na transferência de renda condicionada, isto é, nos procedimentos que envolvem o Bolsa Família. Seja no controle das condicionalidades do programa, no planejamento e execução de ações específicas para esse público, na qual se destaca a inclusão produtiva.

Foi possível observar, que as iniciativas relacionadas à inclusão produtiva presentes na política de assistência social ocorrem basicamente de duas maneiras: de forma direta, isto é, quando as próprias unidades executam cursos de qualificação ou profissionalização; ou indiretamente, com execução por outras instituições, mediante encaminhamento dos usuários. Em ambas as formas, existe um aspecto de valorização subjetiva da ação, presente no discurso da autonomia e empoderamento dos usuários, que encobre a contradição existente com o trabalho e as ideias subjacentes a essa lógica, na qual são exemplos a dependência e a estigmatização do indivíduo pobre por sua condição. Os resultados alcançados corroboram essa questão e mostram que os municípios brasileiros têm investido amplamente em mecanismos de inclusão produtiva, seja através da geração de renda ou qualificação profissional.

Uma das principais estratégias de ativação utilizada pela assistência social nos últimos anos ocorre através do PRONATEC - BSM. O programa criado pelo governo federal em articulação com o Plano Brasil Sem Miséria, direciona ações de qualificação profissional àqueles inscritos ou em processo de inscrição no CadÚnico e beneficiários de transferência de renda. Os resultados da pesquisa demonstram que o PRONATEC - BSM reforça os mecanismos de focalização, na medida em que prioriza um público específico, ao mesmo tempo em que falha na ativação deste, tendo em vista as limitações dos cursos de qualificação existentes, o nível de escolarização dos usuários e a dificuldade de acesso ao mercado de trabalho.

A abrangência do programa também é questionável, o que pode ser verificado com a comparação do número de matrículas no PRONATEC - BSM, com a quantidade de beneficiários do Bolsa Família e daqueles inscritos no CadÚnico, o que demonstra que a continuação do programa pode ser atribuída ao apelo político que possui e ao viés ideológico implícito, de que aqueles que recebem transferência de renda e/ou são usuários da assistência social estão sendo capacitados para buscar uma forma de sobrevivência através do trabalho, sem depender do benefício. Além disso, o PRONATEC - BSM fortalece o mercado privado, ao repassar recursos às instituições particulares de ensino. Dessa forma, entende-se que a 
análise do programa, por se tratar de um estudo de caso, conseguiu demonstrar que a política de assistência social brasileira vem incorporando a lógica do workfare, por meio de medidas de ativação de seus demandantes, ainda que não exista um caráter punitivo e de obrigatoriedade como em outros países, o que confirma a hipótese inicialmente defendida neste estudo.

Apesar da perspectiva crítica adotada nesta dissertação, é importante realizar algumas mediações necessárias. É inegável que nos últimos anos, principalmente a partir do governo Lula, a política de assistência social teve um significativo avanço em sua concepção, normatização e operacionalização. O SUAS, organizado como sistema público, descentralizado e participativo permitiu a expansão dos serviços socioassistenciais padronizados em todo o país. Contudo, essas conquistas nunca estiveram tão ameaçadas. Devido a sanha de Michel Temer em legitimar seu governo voltado aos interesses do capital, vem sendo tomadas medidas que reforçam a concepção conservadora da assistência social. Nesta conjuntura, a perspectiva vislumbrada é que cada vez mais serão incorporadas medidas de ativação para o trabalho pela política de assistência social e pelos programas de transferência condicionada de renda, reforçando cada vez mais a lógica perversa do workfare.

Face ao exposto, destaca-se a importância da realização de novos estudos sobre a temática abordada nesta dissertação, que possibilitem a compreensão da realidade concreta, por meio da análise crítica das determinações presentes na conjuntura política e econômica atual. 


\section{REFERÊNCIAS BIBLIOGRÁFICAS}

ABRAHAMSON, P. O retorno das medidas de ativação na política de bem-estar dinamarquesa: emprego e proteção social na Dinamarca. In: SER Social, Brasília, v. 11, n.25, p. 244-273, 2009.

ALVES, G. Trabalho e neodesenvolvimentismo: choque de capitalismo e nova degradação do trabalho no Brasil. Bauru: Canal 6, 2014.

ANTUNES, R. O caracol e sua concha: ensaios sobre a nova morfologia do trabalho. São Paulo: Boitempo, 2005.

Os sentidos do trabalho: ensaio sobre a afirmação e a negação do trabalho. São Paulo: Boitempo, 2009.

Adeus ao trabalho? Ensaio sobre as metamorfoses e a centralidade do mundo do trabalho. São Paulo: Cortez, 2011.

As formas contemporâneas de trabalho e a desconstrução dos direitos sociais. In: SILVA, M. O. S. e YAZBECK, M. C. (Orgs.). Políticas públicas de trabalho e renda no Brasil contemporâneo. São Paulo: Cortez, 2012.

ARIENTI, L. W. Do Estado keynesiano ao Estado schumpeteriano. Revista de Economia Política, vol. 23, nº 4 (92), outubro-dezembro 2003.

BARBOSA, L. Igualdade e meritocracia: a ética do desempenho nas sociedades modernas. Rio de Janeiro: Editora FGV, 2003.

BARBOSA, R. N. C. A economia solidária como política pública: uma tendência de geração de renda e ressignificação do trabalho no Brasil. São Paulo: Cortez, 2007. 
A feição workfareana das políticas públicas na era da flexibilização capitalista.

Anais do $14^{\circ}$ Congresso Brasileiro de Assistentes Sociais-Águas de Lindóia, São Paulo, 2013.

BEHRING, E. Acumulação capitalista, fundo público e política social. In: Boschetti, I. Et al. (Orgs.). Política social no capitalismo: tendências contemporâneas. São Paulo: Cortez, 2008a.

Brasil em contra-reforma: desestruturação do Estado e perda de direitos. São Paulo: Cortez, 2008b.

Expressões políticas da crise e as novas configurações do Estado e da sociedade civil. In: Serviço Social: direitos e competências profissionais. Brasília: CFESS/ABEPSS, 2009.

Trabalho e seguridade social: o neoconservadorismo nas políticas sociais. In:

Behring, E.; Almeida, M. H. T. (Orgs.). Trabalho e seguridade social: percursos e dilemas. São Paulo: Cortez, 2010.

Rotação do capital e crise: fundamentos para compreender o fundo público e a política social. In: Salvador, E. et al. (Orgs.). Financeirização, fundo público e política social. São Paulo: Cortez, 2012.

BEHRING, E. R.; BOSCHETTI, I. Política social: fundamentos e história. São Paulo: Cortez, 2008.

BOSCHETTI, I. Assistência Social no Brasil: um direito entre originalidade e conservadorismo. Brasília: Ivanete Boschetti, 2003.

Seguridade social e trabalho: paradoxos na construção das políticas de previdência e assistência social no Brasil. Brasília: Letras Livres, Editora UnB, 2006. 
Avaliação de políticas, programas e projetos sociais. In: CFESS/ABEPSS (Orgs.).

Serviço Social: direitos sociais e competências profissionais. Brasília: CFESS/ABEPSS, 2009.

Os custos da crise para a política social. In: Boschetti, I. Et al. (Orgs.). Capitalismo em crise, política social e direitos. São Paulo: Cortez, 2010.

América Latina, política social e pobreza: "novo" modelo de desenvolvimento?. In: Salvador, E. Et al. (Orgs.). Financeirização, fundo público e política social. São Paulo: Cortez, 2012a.

A insidiosa corrosão dos sistemas de proteção social europeus. Revista Serviço Social e Sociedade, $n^{\circ} 113$. São Paulo: Cortez, 2012b. Assistência social e trabalho no capitalismo. São Paulo: Cortez, 2016.

BOSCHETTI, I.; TEIXEIRA, S. O.; SALVADOR, E. A Assistência Social após 20 anos de LOAS: fim da travessia do deserto?. In: Souza e Silva, M. (Org.). Gerontologia: Saúde, Assistência e Previdência. 1ed.Cuiabá: EdUFMT (Editora da Universidade Federal de Mato Grosso), p. 17-36, 2013.

BRASIL. Ministério do Trabalho e Emprego. Secretaria de Políticas Públicas de Emprego. PLANFOR: Plano Nacional de Qualificação do Trabalhador. Brasília, 2001.

Ministério do Trabalho e Emprego. Conselho Deliberativo do Fundo de Amparo ao Trabalhador. Resolução No 333, de 10 de julho de 2003.

Presidência da República. Lei 12.513, de 26 de outubro de 2011.

Ministério do Desenvolvimento Social e Combate à Fome. Secretaria de Avaliação e Gestão da Informação. Estudo qualitativo junto aos alunos egressos e desistentes, 
representantes das unidades ofertantes e interlocutores municipais do Pronatec - Brasil Sem Miséria. In: Cadernos de Estudos Desenvolvimento em Debate, nº 16, 2014.

CARCANHOLO, M. D. (Im)precisões sobre a categoria superexploração da força de trabalho. In: FILHO, A. N. (Org.). Desenvolvimento e dependência: cátedra Ruy Mauro Marini. Brasília: IPEA, 2013.

CARDOSO, L. A. A categoria trabalho no capitalismo contemporâneo. Tempo Social, Revista de Sociologia da USP, v. 23, n. 2, 2011.

CASTEL, R. As metamorfoses da questão social: uma crônica do salário. Petrópolis: Vozes, 1998.

CHESNAIS, F. A mundialização do capital. São Paulo: Xamã, 1996.

COUTO, B. R. O direito social e a assistência social na sociedade brasileira: uma equação possível?. São Paulo: Cortez, 2010.

Assistência social: direito social ou benesse?. Serv. Soc. Soc., São Paulo, n. 124, p. 665-677, out./dez. 2015.

COUTO, B. R.; YAZBEK, M. C.; SILVA E SILVA, M. O.; RAICHELIS, R. O Sistema Único de Assistência Social no Brasil: uma realidade em movimento. São Paulo: Cortez, 2012.

DURANA, A. A.G; ERANSUS, B. P. La última red de protección social em España: prestaciones asistenciales y su activación. Política y Sociedad, vol. 44, Núm. 2, 115-133, 2007.

ENGELS, F. Sobre o papel do trabalho na transformação do macaco em homem. São Paulo: Ridendo Castigat Mores, 1999. 
ERANSUS, B. G. Políticas de Activación y rentas mínimas. Madrid: Fundación Foessa, 2005.

Rentas mínimas y políticas de activación. Revista Documentacion Social, nº 143, 2006.

FILHO, C. G. A questão social no Brasil: crítica ao discurso político. Rio de Janeiro: Civilização Brasileira, 1982.

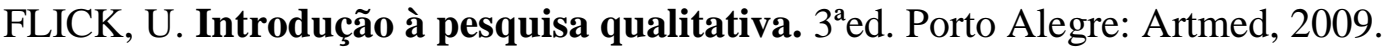

GOFFMAN, E. Estigma: notas sobre a manipulação da identidade deteriorada. Rio de Janeiro: LTC, 2008.

GOUGH, I. Economia política del Estado del bienestar. Trad. De Gregorio Rodriguez Cabrero. Madrid: Blume Ediciones, 1982.

Capital global, necesidades básicas y políticas sociales: ensayos seleccionados 1994-99. Buenos Aires: CIEPP, 2003.

GRAMSCI, A. Cuadernos de la Cárcel - Tomo 3. Turín: Ediciones Era, 1984.

Cadernos do Cárcere - Volume II. Rio de Janeiro: Civilização Brasileira, 2001.

HARVEY, D. Para entender o Capital - Livro I. São Paulo: Boitempo, 2013.

HESPANHA, P.; MATOS. A. R. Compulsão ao trabalho ou emancipação pelo trabalho? Para um debate sobre as políticas ativas de emprego. Sociologias, Porto Alegre, ano 2, jul/dez 2000. 
IAMAMOTO, M. V. Estado, classes trabalhadoras e política social no Brasil. In: Bochetti, I. et al. (Org.). Política social no capitalismo: tendências contemporâneas. São Paulo: Cortez, 2008.

Trabalho e indivíduo social: um estudo sobre a condição operária na agroindústria canavieira paulista. São Paulo: Cortez, 2012.

JESSOP, B. Towards a Schumpeterian Workfare State? Preliminary Remarks on PostFordist Political Economy. Studies em Political Economy, 40, Spring: 7-39, 1993.

JESSOP, R. El futuro del Estado capitalista. Madrid: Los libros de Catarata, 2008.

JUNIOR, A. A. S; NASCIMENTO, C. M. Desemprego crônico e superpopulação relativa: apontamentos a partir da crítica da economia política. Revista Textos e Contextos. Porto Alegre, v. 12, n.1, p. 20-32, jan./jun. 2013.

LAVILLE, J. L. Inserção e workfare na Europa: perspectiva histórica e ideológica Reflexões a partir do exemplo francês. Seminário Europeu políticas e instrumentos de combate à pobreza da união europeia: a garantia de um rendimento mínimo. Almancil: IDS, 1-2 fevereiro, p.141-165, 2000.

LENIN, V. I. O Estado e a revolução: o que ensina o marxismo sobre o Estado e o papel do proletariado na Revolução. São Paulo: Centauro, 2007.

LORENZO, F. Flexiseguridad: opontunidades y riesgos em el actual mercado de trabajo. Lan Harremanak (17-34), 2008.

LUKÁCS, G. A Ontologia do Ser Social II. São Paulo: Boitempo Editorial, 2013.

MANDEL, E. O capitalismo tardio. São Paulo: Abril Cultural, 1982 A crise do capital. São Paulo: Editora da Unicamp, 1990. 
MARINI, R. M. Dialéctica de la dependência. América Latina, dependencia y

globalización. Fundamentos conceptuales Ruy Mauro Marini. Bogotá: CLACSO, 2008.

MARSHALL, T. H. Cidadania, classe social e status. Rio de Janeiro: Zahar, 1967.

MÁRQUEZ, G. M. La reformulación del Estado del bienestar: el workfare, las políticas activas de empleo y las rentas mínimas. Ekayna: junho, 2008.

MARX, K. O Capital: crítica da economia política - Volume 1 Tomo 2. São Paulo: Abril Cultural, 1984.

O Capital: crítica da economia política - Tomo II. São Paulo: Nova Cultural, 1996.

Manuscritos econômico - filosóficos. São Paulo: Boitempo, 2004.

Sobre a questão judaica. São Paulo: Boitempo, 2010.

O Capital: crítica da economia política - Livro I. Rio de Janeiro: Civilização

Brasileira, 2013.

MARX, K.; F. ENGELS. Manifesto do partido comunista. São Paulo: Companhia das Letras, 2012.

MAURIEL, A. P. O. Pobreza, seguridade e assistência social: desafios da política social brasileira. Revista Katalysis. Florianópolis: v. 13, n.2, p. 173-180, 2010.

MÉSZAROS, I. A educação para além do capital. São Paulo: Boitempo, 2008.

A crise estrutural do Capital. São Paulo: Boitempo, 2009.

Para Além do Capital: rumo a uma teoria de transição. São Paulo, Boitempo, 2011. 
MINAYO, M. C. S. Ciência, técnica e arte: o desafio da pesquisa social. In: Minayo, M. C. S. (Org.). Pesquisa social: teoria, método e criatividade. Petrópolis: Vozes, 1994.

MOSER, L. A nova geração de políticas sociais no contexto europeu: workfare e medidas de ativação. Revista Katálysis, Florianópolis, v. 14, n.1, p. 68-77, jan./jun. 2011.

MOTA, A. E. Crise contemporânea e as transformações na produção capitalista. In: Serviço Social: direitos e competências profissionais. Brasília: CFESS/ABEPSS, 2009.

O fetiche da assistência social. In: Mota, A. E. (Org.). O mito da assistência social: ensaios sobre Estado, política e sociedade. São Paulo: Cortez, 2010.

Cultura da crise seguridade social: um estudo sobre as tendências da previdência e da assistência social brasileira nos anos 80 e 90. São Paulo: Cortez, 2011.

MOTA, A. E.; MARAANHÃO, C. E.; SITCOVSKY, M. As tendências da política de assistência social, o SUAS e a formação profissional. In: Mota, A. E. (Org.). O mito da assistência social: ensaios sobre Estado, política e sociedade. São Paulo: Cortez, 2010.

MONTANO, C. Pobreza, “questão social” e seu enfrentamento. In: Revista Serviço Social e Sociedade, nº110. São Paulo: Cortez, 2012.

MONTANO, C.; DURIGUETTO, M. L. Estado, classe e movimento social. São Paulo: Cortez, 2011.

NETTO, J. P. Introdução ao método na teoria social. In: CFESS/ABEPSS (Orgs.). Serviço Social: direitos sociais e competências profissionais. Brasília: CFESS/ABEPSS, 2009.

Crise do capital e consequências societárias. Serviço Social e Sociedade, São Paulo, n. 111, p. 413-429, jul./set 2012. 
NETTO, J. P.; BRAZ, M. Economia política: uma introdução crítica. São Paulo: Cortez, 2011.

OLIVEIRA, A. O. Superpopulação relativa e a "nova questão social": um convite às categorias marxianas. Revista Katálysis, Florianópolis, v. 13, n. 2, p. 276-283, jul./dez 2010.

OLIVEIRA, E. A. A política de emprego no Brasil: o caminho da flexisegurança. Serv. Soc. Soc. São Paulo, n. 111, p. 493-508, jul./set. 2012.

PAIVA, B. A. A enigmática contradição entre trabalho e política de assistência social. In: Paiva, B. A. (Org.). Sistema Único de Assistência Social em perspectiva: direitos, política pública e superexploração. São Paulo: Veras Editora, 2014.

PASCUAL, A. S; RODRIGUEZ, C. J. F.; LEIRAS, A. A. Ingenierías de la subjetividade: el caso de la orientación para el empleo. Reis, 138, abril-junio, pp. 41-62, 2012.

PEREIRA, C. P. Proteção social no capitalismo: crítica a teorias e ideologias conflitantes. São Paulo: Cortez, 2016.

PEREIRA, C. P.; AMORIM, A. A. S. Pobreza no Brasil e na América Latina: concepções restritas sobre realidades complexas. Argumentum, Vitória, v. 2, n. 2, p. 132-148, jul./dez. 2010.

PEREIRA-PEREIRA. P. A. A assistência social na perspectiva dos direitos: crítica aos padrões dominantes de proteção aos pobres no Brasil. Brasília: Thesaurus, 1996.

Política social: temas e questões. São Paulo: Cortez, 2008.

Do Estado Social ao Estado anti-social. In: Potyara Amazoneida P. Pereira et al. (Orgs.). Política Social, trabalho e democracia em questão. Brasília: Universidade de Brasília, Programa de Pós-Graduação em Política Social (PPGPS), 2009. 
Política Social do segundo pós-guerra: ascensão e declínio. Serviço Social e Saúde.

UNICAMP - Campinas, v.IX, n.10, Dez. 2010.

Utopias desenvolvimentistas e política social no Brasil. Serviço Social e Sociedade, n. 112, p. 729-753, out./dez., 2012.

Proteção social contemporânea: cui prodest?. Serviço Social e Sociedade, n. 116, p. 636-651, out./dez., 2013

PEREIRA-PEREIRA, P. A. P.; STEIN, R. Política social: universalidade versus focalização. Um olhar sobre a América Latina. In: Boschetti, I. Et al. (Orgs.). Capitalismo em crise, política social e direitos. São Paulo: Cortez, 2010.

PIERSON, C. Beyond the Welfare State?. Cambridge: Polity Press, 1991.

POCHMANN, M. Rumos da política do trabalho no Brasil. In: M. O., SILVA E SILVA; M. C., YAZBEK (Orgs.). Políticas públicas de trabalho e renda no Brasil contemporâneo. São Paulo: Cortez, 2012.

POULANTZAS, N. Estado, poder y socialismo. España: Sigio Veintiuno Editores, 1979.

RICHARDSON, R. J. Pesquisa social: métodos e técnicas. São Paulo: Atlas, 2010.

SALVADOR, E. Fundo público e seguridade social no Brasil. São Paulo: Cortez, 2010.

SEN, A. Desenvolvimento com liberdade. São Paulo: Companhia das Letras, 2010.

SILVA, M. M. Assistência social na realidade municipal: o SUAS e a prevalência do conservadorismo. Revista Katálysis. Florianópolis, v. 18, n. 1, p. 41-49, jan./jun. 2015.

SILVA, M. O. S.; YASBEK, M. C. Políticas públicas de trabalho e renda no Brasil contemporâneo: tema e conteúdo do livro. In: M. O., SILVA E SILVA; M. C., YAZBEK 
(Orgs.). Políticas públicas de trabalho e renda no Brasil contemporâneo. São Paulo: Cortez, 2012.

SIQUEIRA, L. Pobreza e Serviço Social: diferentes concepções e compromissos políticos. São Paulo: Cortez, 2013.

SITCOVSKY, M. Particularidades da expansão da assistência social no Brasil. In: Mota, A. E. (Org.). O mito da assistência social: ensaios sobre Estado, política e sociedade. São Paulo: Cortez, 2010a.

Conciliações e contradições entre assistência social e trabalho: 0 impacto do Bolsa Família.. In: Mota, A. E. (Org.). As ideologias da contrarreforma e o Serviço Social. Recife, 2010b.

SOUZA, F. V. F. Assistência social e inclusão produtiva: algumas indagações. O Social em questão. Ano XVII - nº 30, 2013.

SOUSA, S. M. P. S.; PEREIRA, M. E. F. D. A apropriação da noção de competência nas políticas de educação profissional desenvolvidas no Brasil a partir dos anos 1990. In: $\mathrm{M}$. O., SILVA E SILVA; M. C., YAZBEK (Orgs.). Políticas públicas de trabalho e renda no Brasil contemporâneo. São Paulo: Cortez, 2012.

UGÁ, V. D. A questão social como "pobreza": crítica à conceituação neoliberal. Curitiba: Appris, 2011.

WACQUANT, L. Punir os pobres: a nova gestão da miséria nos Estados Unidos. Rio de janeiro: Revan, 2003.

A tempestade global da lei e ordem: sobre punição e neoliberalismo. Revista Sociologia Política. Curitiba, v. 20, n. 41, p. 7-20, fe. 2012. 
YIN, R. Estudo de caso: planejamento e métodos. São Paulo: Bookman Editora LTDA, 2015 . 